\title{
Analysis of the Development Options to Improve the Income Situation of Dairying Households in Punjab
}

\author{
Dissertation \\ to obtain the Ph.D degree \\ in the Faculty of Agricultural Sciences, \\ Georg-August-University Göttingen, Germany \\ presented by \\ Khalid Mahmood \\ born in Layyah
}

Braunschweig, May 2008 
D7

Referent: Prof. Dr. Folkhard Isermeyer

Korreferent: Prof. Dr. Ludwig Theuvsen

Tag der mündlichen Prüfung: 13.Mai 2008 
DEDICATED TO MY PARENTS AND BELOUED DIFE NOSHEEN 


\section{Acknowledgement}

I am thankful to ALLAH Almighty for giving me light and courage to work on this subject. May Allah shower blessings on HIS HOLY Prophet MUHAMMAD (PBUH) from whose Hadith I took lesson to complete this task. I am thankful to all those individuals and institutions that have supported towards the completion of this study. Thanks are due to my supervisor, Prof. Dr. Folkhard Isermeyer, who always provided guidance, encouragement, and constructive criticism in a most friendly, organised and timely manner. I would like to mention here the support of Prof. Dr. Winfried Manig from Institute of rural development from University of Göttingen and very much thankful to his valuable inputs and critics. My personal gratitude is to my Prof. Dr. Ludwig Theuvsen from university of Göttingen, who always gave a critical feed back on my seminar paper and later on an expert opinion to refine my research work. I am especially thankful to Higher Education Commission (HEC) of Pakistan for partial support of my last year of PhD. The technical support extended by Dr. Muhmmad Azeam Khan coordinator ICARDA during my stay in Pakistan was an essential part that helped me a lot to understand the situation of dairying households and line up my research work. The logistics support by Dr. Akhter Ali director, Fodder Research Institute, Sargodha was marvellous. I am very grateful to his extension staff and my cousin Riaz Ahmad who were always with me in the fields even in the odd times. The support of my colleague Habib ur Rehman in discussions is highly appreciated.

I would like to express my sincere appreciation to my lovely wife Nosh who always pushed and supported me in completion of my studies. I consider that with out her great help this could never have happened. I am also grateful to both of my daughters Hibba and Hafsa who showed patience and spared me while I was taking time out of their playing time. I am very much thankful to both of my kind and loving parents Mukhtar Ahmad and Rehmat Bibi. I also acknowledge the prays and wishes made by uncle (late) Muhammad Ramzan and Khala Rukhsana. I am especially thankful to my elder brother Afzal Hussain who supported and encouraged me throughout my educational career. Sincere thanks to my whole family member including sisters, brothers and their children i.e. Kalsoom Baji, Nasim Baji, Kauser, Nusrat, Safder and Tariq for their continuous backing throughout my educational career. Many thanks to Sana behn for extending support in formatting.

In the end, I would like to appreciate the support of Frau Annerose Gillner and Frau Karin Dittrich for formatting the thesis. My sincere thanks to many of those whose names are not mentioned here but who always helped me; they are my kind teachers, friends, family members and colleagues from farm economics institute, former FAL (vTI).

Braunschweig, May 13, 2008

Khalid Mahmood 


\begin{abstract}
The aim of this research work is to develop an analytical framework for status quo analysis of milk production situation in Pakistani Punjab and evaluate the impact of various improvement interventions on the income of farm households involved in dairying. The district Sargodha is selected as the study region under mixed cropping system from irrigated region of Punjab for conducting the dairying farm household survey. The data was collected in a cross sectional survey in winter 2005 from a sample of 36 dairying farm households from two villages located in the radius of $25 \mathrm{~km}$ from the district headquarter of Sargodha. The farm types are classified into three groups of small, medium and large scale farm types depending on the size of cultivated. The characteristics of farm types are explained through describing the case studies, results of cross sectional survey and typical farms.
\end{abstract}

The analysis found that the land holding varies from 1 to 10 acres, 10 to 20 acres and more than 20 acres for small, medium and large scale farm types. The average number of milking animals varies from 3 to 10 among all three farm types. The small scale farms sell highest percentage of the total milk produced on the farm as compared to medium and large scale farm types. The small scale farms are more dependent on dairy income as a source of subsistence than medium and large farm types. The crop farming is the major focus of medium and large farm types to produce grain for home consumption and sell rest in the market. In medium and large scale farm type's, the dairy enterprise is not considered as a commercial activity but rather a supplement to the crop farming.

The animal productivity is observed to be very low in small scale farms as compared to medium and large scale farm types mainly due to poor feeding, breeding, longer intercalving periods and higher mortality rates, etc. The small-scale farm type dominates in this region. It is important to improve the productivity of small-scale farm type to increase the income situation of households involved. Four improvement intervention scenarios are selected to measure the impact on the household income in a typical farm type PU-3 through partial budgeting technique. The improvement is compared through ex-ante simulation with the baseline farm PU-3. The evaluated improvement interventions are fodder improvement, husbandry and health improvement, breeding improvement and marketing improvement. The study concludes that the impact of breed improvement is the highest with an increase in household income by 38 percent from US\$ 0.83 per capita in baseline PU-3 to US\$ 1.18 per capita. The husbandry and health improvement showed second highest increase in per capita income by 21 percent with US\$ 1.02 per capita per day. The two other scenarios of fodder improvement and perceived increased milk prices have showed an increase of 7 and 2 percent respectively. The improvement fodder and marketing scenario have not showed a significant difference in the household income. 


\section{Zusammenfassung}

Das Ziel dieser Forschungsarbeit ist es, einen analytischen Rahmen für eine Status-quoAnalyse der Situation der Milchproduktion im pakistanischen Punjab zu entwickeln und die Wirkung von verschiedenen Verbesserungsmaßnahmen auf das Einkommen landwirtschaftlicher Haushalte mit Milcherzeugung zu beurteilen. Der Bezirk Sargodha, der typisch ist für Bewässerungslandwirtschaft im Punjab, wurde als Untersuchungsregion für die Betriebserhebung ausgewählt. Die Daten wurden im Winter 2005 als Querschnittserhebung in einer Stichprobe von 36 Milchwirtschaftsbetrieben in zwei Dörfern, die sich im Radius von $25 \mathrm{~km}$ im Bezirk befinden, erhoben. Die Betriebstypen sind in Abhängigkeit von der bewirtschafteten Fläche in drei Gruppen - kleine, mittlere und große Betriebe - eingeteilt. Die Merkmale der Betriebstypen werden anhand deskriptiver Statistik beschrieben.

Die Auswertung ergab, dass der Landbesitz von 1 bis 10 Morgen, 10 bis 20 Morgen und mehr als 20 Morgen für kleine, mittlere und große Betriebe variiert. Die durchschnittliche Zahl gemolkener Kühe bzw. Büffel variiert von 3 bis 10 in allen drei Bauernhoftypen. Im Vergleich zu den mittleren und großen Betrieben ist bei den kleinen Betrieben der Anteil verkaufter Milch am höchsten. Die kleinen Bauernhöfe sind vom Einkommen aus Milcherzeugung abhängiger als mittlere und große Betriebe. Der Anbau von Ackerfrüchten zur Verwendung im Haushalt und Verkauf stellt den Produktionsschwerpunkt von mittleren und großen Betrieben dar. In mittleren und großen Betrieben wird die Milcherzeugung nicht als eine kommerzielle Aktivität betrieben, sondern eher in Ergänzung zum Ackerbau. Die Produktivität der Tierhaltung ist in kleinen Betrieben deutlich geringer als in großen; kleine Betriebe weisen einen geringeren Futtereinsatz, eine niedrige Milchleistung, längere Zwischenkalbezeit und höhere Tierverluste auf. Kleine Betriebe dominieren in dieser Region.

Es ist wichtig, die Produktivität der kleinen Betriebe und deren Einkommenssituation zu verbessern. Vier Verbesserungsmaßnahmen wurden als Szenarien ausgewählt, um die Wirkung auf das Haushaltseinkommen eines typischen Bauernhofes vom Typ PU-3 auf der Grundlage von Planungsrechnungen $\mathrm{zu}$ bewerten. Die partiellen Effekte der Verbesserungsmaßnahmen werden ex ante im Vergleich zur Baseline von PU-3 mittels Simulationsrechnungen abgeschätzt. Die beurteilten Verbesserungseingriffe sind eine verbesserte Fütterung, Milchleistungssteigerung und Verbesserungen der Haltungsbedingungen und der Tiergesundheit. Die Studie kommt zu dem Ergebnis, dass die Wirkung der Züchtung (Milchleistungssteigerung) mit einer Zunahme des Haushaltungsentgelts je Person um $38 \%$ von US\$ 0,83 pro Kopf und Tag im Ausgangsniveau PU-3 auf US\$ 1,18 am höchsten ist. Die Verbesserung der Haltungsbedingungen und der Tiergesundheit zeigte die zweite höchste Erhöhung des ProKopf-Einkommens von $21 \%$ auf US\$ 1,02 pro Kopf und Tag. Die zwei anderen Szenarien von Futterverbesserung und höheren Milchpreisen führen zu einem Einkommenszuwachs von 
7 bzw. $2 \%$. Die Verbesserung der Fütterung und Vermarktung haben keine bedeutsame Differenz im Haushaltungsgeld gezeigt. 


\section{Table of Contents}

$\begin{array}{lll}\text { Acknowledgement } & \text { IV }\end{array}$

$\begin{array}{ll}\text { Abstract } & \text { i }\end{array}$

Zusammenfassung ii

1 Introduction 1

1.1 Background 1

1.2 Problem 1

1.3 Objectives 2

1.4 Organization of the Study 2

2 Description of the Study Area 3

2.1 Agriculture and Dairy Sector Situation in Pakistan 3

2.1.1 Agriculture sector 3

2.1.2 Dairy sector 5

2.2 Punjab, Agriculture and Dairy Sector Profile 9

2.2.1 Situation of Punjab agriculture 9

$\begin{array}{ll}\text { 2.2.2 Milk production situation in Punjab } & 14\end{array}$

2.3 Selection of Sargodha District and its Profile 16

$\begin{array}{lll}\text { 2.3.1 Geographical statistics of Sargodha district } & 18\end{array}$

2.3.2 Weather data of Sargodha district 20

3 Method $\quad 22$

3.1 Method Review 23

$\begin{array}{lll}3.2 & \text { Analytical Framework } & 25\end{array}$

$\begin{array}{lll}3.2 .1 & \text { Selection of study area } & 26\end{array}$

$\begin{array}{lll}3.2 .2 & \text { Selection of villages } & 27\end{array}$

$\begin{array}{lll}3.2 .3 & \text { Selection of sample size } & 29\end{array}$

3.2.4 Selection of the farm households 31

3.3 Case Study Approach 31

$3.4 \quad$ Selection of Typical Farm 32

3.5 Intervention Scenario Evaluation 37 
4 Results and Discussion $\quad 42$

4.1 Group I, Small-scale Farm Type 43

4.1.1 A case study of small-scale farm 43

4.1.2 Survey results of group I: small-scale farm type 49

4.1.3 Typical farm-PU3 53

4.2 Group II, Medium Size Farm 53

4.2.1 A case study of medium size farm type 53

$\begin{array}{lll}\text { 4.2.2 } & \text { Survey results of group II, medium size farm } & 59\end{array}$

$\begin{array}{lll}4.2 .3 & \text { Typical farm-PU-6 } & 63\end{array}$

$\begin{array}{lll}4.3 & \text { Group III, Large Scale Farm } & 63\end{array}$

$\begin{array}{lll}\text { 4.3.1 A case study of large scale farm } & 63\end{array}$

4.3.2 Survey results of group III, large scale farm type 68

$\begin{array}{lll}\text { 4.3.3 Typical farm-PU-9 } & 72\end{array}$

4.4 Comparison 73

4.4.1 Cross comparison of farm household survey results 73

$\begin{array}{lll}\text { 4.4.2 Typical farms comparison } & 77\end{array}$

4.5 Evaluating Development Interventions $\quad 85$

4.5.1 Fodder improvement scenario 86

4.5.2 Animal husbandry and health improvement scenario 90

4.5.3 Breed improvement scenario 93

4.5.4 Perceived higher milk prices-marketing scenario 96

4.5.5 Comparison of the improvement interventions 97

5 Conclusion $\quad 101$

$\begin{array}{lll}6 & \text { Summary } & 103\end{array}$

$\begin{array}{ll}\text { Literature Index } & 106\end{array}$

$\begin{array}{lr}\text { Annex } & 116-141\end{array}$

\section{Curriculum Vitae}




\section{List of Tables}

Table 1: $\quad$ The provinces share in area, land resources and human population $\quad 4$

$\begin{array}{lll}\text { Table 2: } & \text { The share of provinces in milk production } & 10\end{array}$

Table 3: $\quad$ Geographical data of Punjab 10

Table 4: $\quad$ Land holding $\quad 11$

Table 5: $\quad$ Irrigated area 11

Table 6: $\quad$ Farm structure in Pakistani Punjab 11

Table 7: $\quad$ Percent of land used by different crops in Pakistani Punjab $\quad 14$

Table 8: $\quad$ Punjab cattle and buffalo population $2000 \quad 15$

Table 9: $\quad$ Dairy animal’s population of district Sargodha 17

Table 10: $\quad$ General description of the villages 28

Table 11: $\quad$ Example of milk yield calculation per lactation 35

Table 12: $\quad$ Grouping of the sample farm types 43

Table 13: $\quad$ Family demographics $\quad 49$

Table 14: $\quad$ Farm manager's profile 50

Table 15: $\quad$ Farm household's income situation 50

Table 16: $\quad$ Landholding and farm capital 51

Table 17: $\quad$ Farm labour requirements 51

Table 18: $\quad$ Dairy production details $\quad 52$

Table 19: Milk sales and home consumption 52

Table 20: $\quad$ Family demographics 59

Table 21: $\quad$ Farm manager's profile $\quad 59$

Table 22: $\quad$ Farm household's income situation 60

Table 23: $\quad$ Landholding and farm capital $\quad 61$

$\begin{array}{ll}\text { Table 24: } & \text { Labour requirement }\end{array}$

Table 25: $\quad$ Dairy production details $\quad 62$

Table 26: $\quad$ Milk sales and home consumption 62

Table 27: $\quad$ Family demographics $\quad 69$

Table 28: $\quad$ Farm manager's profile $\quad 69$

$\begin{array}{lll}\text { Table 29: } \quad \text { Farm household's income situation } & 70\end{array}$ 
$\begin{array}{lll}\text { Table 30: } & \text { Landholding and farm capital } & 70\end{array}$

$\begin{array}{lll}\text { Table 31: } & \text { Labour requirement } & 71\end{array}$

Table 32: $\quad$ Dairy production and milk marketing details $\quad 71$

Table 33: $\quad$ Milk sales and home consumption 72

$\begin{array}{lll}\text { Table 34: } & \text { Farm household's demographics } & 73\end{array}$

Table 35: $\quad$ Farm household's income $\quad 74$

$\begin{array}{lll}\text { Table 36: } & \text { Land allocation } & 75\end{array}$

$\begin{array}{lll}\text { Table 37: } & \text { Farm assets } & 75\end{array}$

Table 38: $\quad$ Family labour $\quad 76$

$\begin{array}{lll}\text { Table 39: } & \text { Dairy parameters } & 76\end{array}$

Table 40: $\quad$ Milk sales and home consumption 77

$\begin{array}{lll}\text { Table 41: } & \text { Adult man equivalent } & 79\end{array}$

$\begin{array}{lll}\text { Table 42: } & \text { Farm manager's profile } & 79\end{array}$

Table 43: $\quad$ Farm household's living expenses 80

Table 44: $\quad$ Landholding and farm resources 80

Table 45: $\quad$ Household income share from different enterprises 81

Table 46: $\quad$ Farm household's income share $\quad 81$

Table 47: $\quad$ Dairy input costs $\quad 82$

Table 48: $\quad$ Dairy returns $\quad 82$

Table 49: $\quad$ Gross margin of dairy enterprise 83

Table 50: $\quad$ Milk production of three farms 83

Table 51: $\quad$ Herd details $\quad 84$

$\begin{array}{lll}\text { Table 52: } & \text { Livestock sales } & 84\end{array}$

Table 53: $\quad$ Home consumption $\quad 85$

Table 54: $\quad$ Inputs requirement of winter fodder crop-oat 88

Table 55: $\quad$ Inputs requirement of summer fodder -hybrid sorghum 88

Table 56: $\quad$ Post intervention situation: increase in fodder yield 88

Table 57: $\quad$ Post intervention situation: milk yield and farm milk production $\quad 89$

Table 58: $\quad$ Post intervention situation: household income 89

Table 59: $\quad$ Post intervention situation: lactation and dry days 90 
Table 60: $\quad$ Post intervention situation: health and breeding costs $\quad 91$

Table 61: $\quad$ Post intervention situation: mortality rate $\quad 91$

Table 62: $\quad$ Post intervention situation: dry and lactation period 92

Table 63: $\quad$ Post intervention situation: milk yield and livestock sales 92

Table 64: $\quad$ Post intervention situation: household income 93

Table 65: $\quad$ Post intervention situation: milk yield 94

Table 66: $\quad$ Post intervention situation: feeding, health and breeding costs 95

Table 67: $\quad$ Post intervention situation: dairy returns 95

Table 68: $\quad$ Post intervention situation: household income 96

Table 69: $\quad$ Post intervention situation: milk price 96

Table 70: $\quad$ Post intervention situation: transport costs for marketing milk $\quad 97$

Table 71: $\quad$ Post intervention situation: perceived higher milk price 97

Table 72: $\quad$ Post intervention situation: comparison of scenario outputs 98

Table 73: $\quad$ Post intervention situation: household income comparison 99 


\section{List of Figures}

Figure 1: $\quad$ Agroecological zones in Punjab 12

Figure 2: $\quad$ Map of Punjab province with cows and buffaloes dominance 16

Figure 3: $\quad$ Milking animal types in district Sargodha 17

Figure 4: $\quad$ Punjab Province map with location of Sargodha district 19

Figure 5: $\quad$ Annual rainfall pattern of Sargodha district 20

Figure 6: $\quad$ Four years monthly avg. maximum and minimum temperature $\quad 21$

Figure 7: $\quad$ Location of the selected villages 29

Figure 8: $\quad$ Small-scale case study farm 46

Figure 9: $\quad$ Medium size dairy farm in chak no 105 SB Sargodha 56

Figure 10: $\quad$ Animal housing at a medium size farm in chak 105 SB, Sargodha 57

Figure 11: $\quad$ Large scale farm type in 105 SB, Sargodha 66

Figure 12: $\quad$ Farm building structure of the large scale farm type 67

Figure 13: $\quad$ Comparison of improvement interventions as per capita income per day 


\section{Annex - List of Tables and Figures}

Annex 1: $\quad$ Map of Pakistan

Annex 2: $\quad$ Pakistan Agro Ecological zones with major crops, fodder and fruit trees

Annex 3: $\quad$ Land holding structure in Pakistan

Annex 4: $\quad$ Milk production of Pakistan from 1990 to 2005

Annex 5: $\quad$ Milking herd population of Pakistan 1990-2005

Annex 6: $\quad$ Milk yield growth rate from 1990 to 2005

Annex 7: $\quad$ Values of milk and various crops in Pakistan, 1997-2002

Annex 8: $\quad$ Area under irrigation in Punjab

Annex 9: $\quad$ Monthly rainfall data of district Sargodha

Annex 10: $\quad$ Livestock Population of district Sargodha

- Rural (Punjab Census, 2000)

Annex 11: $\quad$ Livestock Population of District Sargodha - Urban

Annex 12: $\quad$ Seasonal variation of milk production

Annex 13: $\quad$ Standardizing family members as Adult man equivalent

Annex 14: $\quad$ Questionnaire Farm households data collection

Annex 15: Questionnaire II detailed information of the farm households/farm parameters

Annex 16: $\quad$ Survey data of the farm households 


\section{Abbreviations}

Acr

AI

CS

CSC

$\mathrm{CP}$

DM

DAP

ECM

$\mathrm{Ft}$

FAO

FRI

GDP

G/d

$\mathrm{Ha}$

Hhs

Kg/ d

IDF

IFAD

IFCN

IK

ILRI

IMP

LDD\&D

MAF

MA

ME

MEq

Mill. Tonnes

MINFAL

PARC

PERI

PK

PU

RS

SMEDA

SNF

SWOG

Sd

Se

TMR

TDN

US\$

$\mathrm{Yr}$
Acre

Artificial insemination

Case study

Cotton seed cakes

Crude protein

Dry matter

Di-ammonium phosphate

Energy corrected milk

Feet

Food and agriculture organization

Fodder research institute, Sargodha

Gross domestic product

Grams per day

Hectare

Households

Kilogram per day

International dairy federation

International fund for agriculture development

International farm comparison network

Idara e kissan

International livestock research institute

Improvement

Livestock and dairy development department

Million acre feet

Milking animals

Metabolisable energy

Milk equivalent

Million tonnes

Ministry of food, agriculture and livestock, government of Pakistan

Pakistan agriculture research council

Punjab economic research institute

Pakistan

Punjab

Pakistani rupees

Small and medium enterprise development authority

solids non fat

Strategic working group on milk

Standard deviation

Standard error

Total mixed ration

Total digestible nutrients

US dollar

Year 


\section{Introduction}

\subsection{Background}

The income from dairy and livestock sector contributes about 34 percent to the agricultural value added output, and 8.3 percent to the country's total gross domestic product (GDP). Dairy sector contributes largely in livestock economy of Pakistan in the form of milk. The share of milk alone is around 60 percent of the total worth of livestock output in the country. Dairy plays an important role to fulfil the nutritional needs and sustain the livelihood of farm households through sale of milk and livestock animals. These small farm holders derive about 30 to 40 percent of their income from dairy (ECONOMIC SURVEY OF PAKISATN, 2004; FAO, 2004; KUROSKAI, 1998; GARCIA et al., 2003).

The small land holders depend more on livestock income than the well-off families. The increasing demand of milk products in the urban areas offers a vast opportunity to small holders to produce milk for sale. There are 38 percent rural households that live below poverty line and make their living with less than US\$1 per day. More than 20 percent of the rural households receive at least 25 percent of their income from livestock resources, and increase in income from livestock results into decrease in income inequality. Livestock development is an effective approach to fight against poverty in rural areas (ADAMS et al., 1995; DELGADO et al., 2001; CHEEMA et al., 1992).

The milk production has shown a consistent growth rate of above 3.5 percent during the last three decades in Pakistan. The trend in growth of milk production is likely to continue due to increase in demand of milk as a result of growing population. There are in total 26 million heads of milking animals that produce about 29 million tonnes of milk per year. More than 70 percent of milk in Pakistan is produced by the small land holders that own less than 2 ha land and keep1-2 animals. The average milk yield per animal is as low as 816 and $1291 \mathrm{~kg}$ per lactation for buffaloes and cows respectively (AGRICULTURE STATISTICS OF PAKISTAN, 2004; FAO, 2004). There is a need to improve the animal productivity to produce more milk through adopting better interventions that can help to improve the income of farm households.

\subsection{Problem}

In spite of the fact that dairy plays an important role in the rural economy of Pakistan, the improvement of dairy in the farm households has been very low. The productivity of farms varies according to their size, location and access to the market. The potential of higher productivity can not be achieved due to various issues faced in production. To achieve the goal of improving the dairy sector, a number of dairy development programs 
have been carried out by the governments from time to time mainly focusing in the field of animal health (HAIDER, 1997).

However, a development strategy should not only focus on the improvement of production technology, but also on the specific situation of decision makers involved in farm households. The farm size varies in Pakistan depending on the location and access to market, while proposing a new development strategy the specific conditions and limitations of a farm household should be taken into consideration.

\subsection{Objectives}

The aim of this research work is to develop an analytical framework to improve the income situation of the farm households involved in dairying in Pakistan. The broad research objectives are;

a) Identification of dairy farm types,

b) Status quo analysis of dairy farm types,

c) Evaluation of improvement interventions to increase the income of household.

Finally the outcome of this research work shall help to find appropriate solutions for policymakers and researchers to choose among various development options that can help to increase the household income through dairying.

\subsection{Organization of the Study}

The study is presented in six chapters. The first chapter explains the general background and role of dairying in farm households. It explains the problem of low milk productivity that causes low income from dairy in household income. The background of general agriculture and dairy sector of Pakistan with special emphasis on Punjab is explained in chapter two. The third chapter explains various approaches and methods used to achieve the research objectives. It elaborates a brief review of the method carried out. Hence the analytical framework of the study and procedures adopted in data analysis are explained in chapter three. The objective wise results are presented and discussed in the fourth chapter. The chapter five concludes the findings of the study. The sixth chapter synthesises and summarizes the findings of the study. 


\section{Description of the Study Area}

This chapter gives an overview of the study area by first explaining the role of agriculture sector in Pakistan's economy, major agro-ecological zones defining cropping patterns depending on the soil, water and climatic conditions. The specific situation of dairy production and importance in rural economy of Pakistan is explained by facts and figures supported through the literature review, etc. The chapter further explains the reasons why Punjab is selected as a region for this research purpose. It is mainly due to its importance in terms of land resources and agriculture output, the contribution in milk production, animal population, human population and diversity of production systems, etc. The Punjab province is divided into agro-ecological zones depending on the cropping patterns in the region to produce forage resources for the dairy animals. The Punjab province is further divided into administrative districts that come under different cropping systems. These districts provide a natural habitat for rearing cows and buffaloes depending upon the availability and types of feeding resources. This chapter also explains why the district Sargodha is selected out of 34 districts in Punjab for this research study. The basic infrastructure and land resources of Sargodha district are explained at the end of this chapter.

\subsection{Agriculture and Dairy Sector Situation in Pakistan}

\subsubsection{Agriculture sector}

Pakistan is the second largest country in South Asia and sixth largest country in the world with 155 million people (POPULATION CENSUS ORGANIZATION, 2002) and is projected to increase to 234 million by 2025 (WYNN et al., 2006). The population density is 200 inhabitants per kilometre square. The average annual population growth is estimated at about 3.2 percent (FAO, 2002). The geographical area of the country is 796,096 square kilometres and bounded by India on the East, to the South connected with the Arabian Sea; the North is partially connected with China and a long border with Afghanistan and Iran in the West. Its geographic coordinates are 30.0N, 70. 0 E.

Pakistan has four main provinces, one independent state of Azad Jamu Kashmir and one federal administrative tribal area (FATA). The four provinces are Punjab, Sindh, Northern Western Frontier Province (NWFP) and Balochistan. Punjab is the largest province in Pakistan with 89 million inhabitants and has 20.6 million hectare land (table 1). 
Table 1: The provinces share in area, land resources and human population

\begin{tabular}{lccc}
\hline & $\begin{array}{c}\text { Area } \\
\text { Square km }\end{array}$ & $\begin{array}{c}\text { Land } \\
\text { million ha }\end{array}$ & $\begin{array}{c}\text { Population } \\
\text { million nos }\end{array}$ \\
\hline Pakistan & 767,969 & 79.5 & 155.2 \\
Punjab & 205,344 & 20.6 & 89.0 \\
Sindh & 140,914 & 14.1 & 36.8 \\
NWFP & 74,521 & 10.2 & 21.4 \\
Baluchistan & 347,190 & 34.6 & 8.0 \\
\hline
\end{tabular}

Source: Derived from Population census Organization 2002 and Agriculture statistics of Pakistan 2005.

Most of the areas in the Punjab and Sindh provinces comprise of plain fields, formed by the River Indus and are dependent on canal irrigation. The country has a remarkable 82 percent of its agricultural area covered by irrigation. About 1.6 million km (1 million miles) are covered by watercourses, farm channels and field ditches. In addition, the irrigation infrastructure is supplemented by 43.4 million acre feet (MAF) groundwater pump age. The huge network of irrigation serves 43 command areas with 45,000 villages, covers 16.22 million hectares of the nation cultivated and cropped area of 22 million hectares. (ECONOMIC SURVEY OF PAKISTAN, 2003-04).

Agriculture is the largest sector of Pakistan's economy. The contribution of agriculture is more than 27 percent in Pakistan's gross domestic product (GDP). More than 67 percent of the country's population lives in the rural areas is directly or indirectly dependent on agriculture for livelihood (ECONOMIC SURVEY OF PAKISTAN, 2003-04). As a result of increase in population, the rural development gain in food and livestock production is important for food security and fight against poverty (WYNN et al., 2006).

Pakistan is divided into 10 agro-ecological zones (AEZs) which include (i) Indus Delta, (ii) Southern irrigated plain, (iii)Sandy desert, (iv) Northern irrigated plains, (v) Barani (rain fed) areas, (vi) Wet mountains, (vii) Northern dry mountains, (viii) Western dry mountains, (ix) Dry western plateau, (x)Suleiman Piedmont (PARC, 1980) (see annex 2).

Most of the land area of Pakistan is classified as arid to semi-arid with 68 percent of the geographical area under annual rainfall of below $250 \mathrm{~mm}$ and about 24 percent of geographical area under annual rainfall of 250 to $500 \mathrm{~mm}$. The highest rainfall of above 500 mm takes place on 8 percent geographical spread in Punjab and in foothills of Northern areas. 
The farm structure in Pakistan is generally dominated by small farms with an average size of 3.78 hectares land. Over all more than 80 percent of the farms have less than 5 hectares of land (see annex 3). There are only 7 percent farms that have land size more than 5 hectares. The farm size decreases due to land fragmentation among the family members as a result of law of inheritance (SHEIKH et al., 2005). Due to continuous land fragmentation, the small farm units become uneconomical for mechanization. This is the reason that still most of the agricultural operations are more labour intensive which are less efficient on one hand and less productive on the other (AGRICULTURE STATISTICS OF PAKISTAN, 2003; YOUNAS et al., 2004).

The crops are sown two times a year in sowing seasons of summer and winter. During summer season the major crops sown are; cotton, rice, sugarcane maize and fodder crops are sorghum and millets which are sown between April and June and harvested before winter. The major crops of winter season are wheat, barley, tobacco, rapeseed and mustard. The winter fodder crops are berseem and alfa alfa. The winter minor crops are pulses, potatoes, onions, chillies and garlic that are sown between October-December and harvested in April and May (KHAN, 1998).

The overall allocation of land for food grains is 56 percent of the total cropped area, 17 percent cash crops, 7 percent pulses, 3 percent oilseeds, 2 percent fruits, 1 percent each for vegetables and condiments and 13 percent for fodder and other crops (MINFAL, 1995).

\subsubsection{Dairy sector}

Pakistan is the $5^{\text {th }}$ largest milk producer in the world with a milk production of 29 million tonnes in the year 2005. The milk is mainly produced from buffaloes which accounts for seventy percent of the total milk production in the country. The total milking herd of buffaloes and cows accounts for 26 million heads ${ }^{1}$. The herd size grows with annual growth rate of 3 percent. The milk yield per animal is very low and the average milk yield reported is 816 and $1291 \mathrm{~kg}$ per lactation per cow and buffalo respectively (FAO, 2004). The dairy sector is an important component of Pakistan's agriculture economy in terms of its contribution to gross domestic product (GDP). The total farm gate value of the raw milk is about Rs 240 billion (US\$ 5 billion) without value addition that exceeds the com-

1 The milking population includes the milking animals, dry animals with out including the females that have not reached maturity, calves and the meat animals. The overall numbers are 26 million heads of buffaloes and 24 million heads of cows. Buffalo is a dominant animal which is more concentrated in irrigated areas and along the riverbank belts. 
bined value of all major crops i.e. wheat, rice, maize, sugarcane and cotton crops in the country (SMEDA, 2002) (see annex for detailed comparison).

Milk animals play an important role to fulfil the nutritional needs of the rural households and sustain their livelihood by generating income from sale of surplus milk and meat animals. Small land holders engage to a large extent the family labour mainly the women and children to raise dairy animals. The dairy animals are fed with green fodder and supplemented with crop residues mainly wheat straw, rice straw etc. A large proportion of dairying households comprise of small, marginal farmers and landless labourers (KUROSKI, 1998).

The buffalo population is more concentrated in irrigated areas along the river belts through out Pakistan. The most common buffalo breeds are Nili Ravi and Kundi which have strong cultural attachment with these breeds in Punjab and Sindh. The cattle population growth rate is slow as compared to buffaloes. The major milk producing cattle breeds are Sahiwal, Cholastani in Punjab and Red Sindhi, Tharparker (dual purpose breed) are found in Sindh. The lactation period of Sahiwal and Red Sindhi breeds vary between 270 to 400 days which is generally longer than buffaloes. In general the specialized breeds are more productive than buffaloes through out summer and supply milk to the households and generate cash flows for the family (WYNN et al., 2006).

Milk production follows a seasonal fluctuation during the summer and winter season. The peak production is seen higher at the end of summer and beginning of winter months due to natural calving season of buffaloes. The flush and lean in production of milk is observed during the winter and summer months respectively (JOST, 1984). The seasonality in milk production affects the milk supply and causes significant difference in milk prices. Producer prices in summer are reported to be 30 percent higher as compared to winter (SCHINZEL, 1979a).

Nutrition is a central issue for small-scale farms as a considerable proportion of food is produced for own home consumption The proportion of agriculture produce from the small-scale farms is very high for home consumption due to their lower production and higher subsistence attitude due to lack of sufficient income (JAFRI, 1999).The poor and non-poor farm households produce 31 percent and 48 percent of all consumed food items respectively measured in monetary terms for home consumption. This implies to staple food items, which actually can be produced on the farm. These food items are mainly selfproduced such as grains. The purchased food items are vegetables, cooking oil, sugar, tea, and fruits (YUCER et al., 2000). 
There are several milk production systems in Pakistan that differ on the basis of location, herd size, cropping pattern and sale of milk, etc (HASNAIN et al., 2006). The milk production systems are very much dependent on the location for having an access to feed resources and the markets to determine the size of the farm and its objectives.

Due to variations in farm size and specific characteristics, the milk production in Pakistan has been classified into five major milk production systems (FAO, 1987) which are;

\section{a). Rural subsistence production system}

It has a herd size of 1 to 2 milking animals with very low productivity. Under this system the animals are fed with green forages collected from uncultivated areas, wheat straw and occasionally purchased feed. Milk is mainly produced to meet the household needs of family consumption and processed into long shelf life dairy products such as butter oil (desi ghee ) (FAO, 1987; SMEDA, 2002).

\section{b). Rural market-oriented small-holder production system}

Under this system a small herd of dairy animals are kept as a supplement to main crop farming activity. The herd size varies between 2 to 3 milking animals mainly buffaloes. About 30 percent of the rural small holders were estimated to have interest in producing milk for sale. The animals are mostly stall-fed with green chopped fodder mixed with wheat or rice straw. Most of the roughages come from the residue of crops grown on the farm. Few exceptions are feeding concentrates as a supplement which is mainly cotton seed cake and wheat bran, etc. The animal breeding is mostly done through natural mating with non descript bulls. The use of artificial insemination technique for breeding is very limited and dependent on the availability. Milk produced under this system is partially consumed at home and surplus is sold locally to the milkman (dhodi) (FAO, 1987).

\section{c). Rural commercial production system}

This system is found mostly in the rural areas that have better access to the nearby large towns or to the milk processing plants for sale of milk. The typical rural commercial system keeps about 20 buffaloes and 5 to10 crossbred cows which are kept besides the crop farming enterprise. About 40 percent of the buffaloes are in milk during most part of the year (HASNAIN et al., 2006). The land holding of the farm is generally more than 10 ha which may be all owned or sometimes part of it is acquired on rent. The farms raise their own heifers. The cows are impregnated through artificial insemination preferably to attain higher productivity. The fodder is chopped mechanically with a fodder chopper. The farm has a tractor and other tillage equipment used for crops and also to grow fodder crops. After home consumption the rest of milk is sold to a trader or to the collection agency of a dairy company (FAO, 1987). 


\section{d). Peri-urban production system}

This system is found in the peri urban areas and in the out skirts of the main towns. The herd size varies from 20-50 milking animals. More than 90 percent of the herd is in milk round the year. The dry animals are replaced with wet animals. Due to closer location to the urban market, this system is mostly commercial in nature. Feeding is more intensive with green fodder supplemented with concentrates. These farms have partial access to their own fodder lands; besides they mostly buy feed resources from the market. They feed relatively higher quantities of concentrate feed to get higher milk yields. The own breeding of herd is very limited because of higher feeding costs. The sale of dry animals and calves is quite higher. The herd size is maintained through replacement with the lactating animals. The system has advantage of direct marketing of milk due to better access to the urban market. The fresh raw milk of both morning and evening milking is sold directly through home delivery and also via the traditional milk shops (HASNAIN et al., 2006; FAO, 1987).

\section{e). Urban production system}

It has large peri-urban commercial farms that have converted to urban commercial dairy farms due to rapid urbanization. The average size of herd is more than 50 milking animals and goes above 200. Under this system more than 95 percent of the dairy animals are buffaloes. Under this system the dairy farms are mostly located in the dairy colonies set up under the municipality of the town (Karachi, Lahore are the key examples of cattle colonies). This system has no agriculture land to grow fodder so it is mostly dependent on purchased feeding resources. Breeding of dry animals is not generally managed on the farms but other arrangements are made to send the dry animals to rural farms for breeding purpose. The milk marketing is managed by direct sale of milk to the consumers or sale through the specialized milk shops (HASNAIN et al., 2006).

The dairy sector is facing problems of lower milk yields caused by inadequate feeding, husbandry and management practices. The genetic potential of most of the herd is very poor that should be improved through continuous breeding programs of progeny selection and crossing local animals with high yielding animals, etc. Generally the farmers are not inclined to accept AI method due to various reasons (BURKI et al., 2005). The AI coverage is less than 10 percent while 90 percent still use the non-descript bulls. The access to AI services is also another reason to choose natural mating (AHMAD et al., 2000).

In general the dairy sector of Pakistan faces issues of lower productivity, seasonality in milk production, fragmented distribution system, lack of mechanization, automation, re- 
frigeration and unhygienic handling of milk leading to poor quality milk, well below international standards $\left(\mathrm{SWOG}^{2}, 2004\right)$.

The milk marketing is dominated by informal sector which collects milk from the rural areas and distributes in the urban areas as unprocessed milk. The market share of un processed milk is more than 95 percent. The formal market share in the form of processed milk and dairy products is below 5 percent (SMEDA, 2002; TEUFEL, 2006).

\subsection{Punjab, Agriculture and Dairy Sector Profile}

\subsubsection{Situation of Punjab agriculture}

The province is densely populated and has 89 million inhabitants. About 40 percent population of the province is employed in agriculture sector. More than 32 percent of the population lives in the urban areas. The total length of metalled roads is 42,307 kilometres. The literacy rate is about 40 percent which is highest as compared to the other provinces of Pakistan (PAKISTAN CENSUS ORGANIZATION, 2004).

The province of Punjab has eight administrative divisions which are Lahore, Faisalabad, Multan, Bhawalpur, Rawalpindi, DG Khan, Gujranwalla and Sargodha. It has 34 administrative districts, 111 tehsiles, 341 markaz (centres) and 2700 union councils (local councils), 24770 villages and 218 urban areas spread over an area of 205,345 square kilometres (AHMAD et al., 2000).

The Punjab province owns 20.60 million hectares of land with 77 percent of the cultivated area as irrigated and 23 percent as rain fed. The over all cultivated area of Punjab accounts for more than the 60 percent of the country's cultivated area. The province has a variety of agricultural production system ranging from mountainous, irrigated plains, rain fed plateaus and deserts. This diversity in the agro-climatic conditions provides prosperous opportunities for growing arable crops i.e. cereal crops, fibre, fodder crops and orchards etc. (AGRICULTURE STATISTICS OF PAKISTAN, 2005).

SWOG: Dairy strategic working group was organized under the Government of Pakistan with Ministry of Industries and production in cooperation with USAID (United States Agency for International Development), PISDC (Pakistan Initiative of Strategic Development and Competitiveness Program) program 2004. One public private partnership company was established in 2005 to work on the dairy development task under the name of Pakistan Dairy Company. 
Punjab plays an important role in the national agriculture production due to its well developed canal irrigation system and the availability of good quality sweet ground water. The ground water is used for irrigation at the time of shortage of water. In early 1990s, Punjab produced about seventy percent of the country's wheat, 80 percent of the cotton, 50 percent of the sugar cane and 50 percent of the rice. The contribution of milk production is about seventy percent due to higher number of milk animals raised in Punjab (AGRICULTURE STATISTICS OF PAKISTAN, 2005).

Table 2: $\quad$ The share of provinces in milk production

\begin{tabular}{lccc}
\hline Cows \& buffaloes & Milk production & share in milk \\
population & million heads & million tonnes & $\begin{array}{c}\text { production } \\
\%\end{array}$ \\
\hline Pakistan & 46.9 & 29.3 & 100 \\
Punjab & 27.5 & 20.1 & 69 \\
Sindh & 13.0 & 8.2 & 28 \\
NWFP & 5.2 & 0.7 & 2 \\
Baluchistan & 1.2 & 0.3 & 1 \\
\hline
\end{tabular}

Source: Derived from Agriculture Statistics of Pakistan 2005 and FAO year book 2005.

Majority of farms are small with a land holding of less than 5 hectares and account for 85 percent of the total farming community. The cropping intensity is 145 percent. There are very few farms (15 percent only) that own more than 5 hectares land (table 3).

The 56 percent of the total cultivated area in Punjab is irrigated by canals and 42 percent through tube wells. Total irrigated area is 6.56 million hectares (KHAN et al., 2000).

Table 3: $\quad$ Geographical data of Punjab

\begin{tabular}{llr}
\hline Geographical area & million hectares & 20.63 \\
Cultivated area & million hectares & 16 \\
Cropping intensity & percent & 145 \\
Total number of farms & million & 3.9 \\
Average farm landholding & hectare & 2.91 \\
\hline
\end{tabular}

Source: Federal Bureau of Statistics, Pakistan. Agriculture Census 2000. 
Table 4: $\quad$ Land holding

\begin{tabular}{lc}
\hline & Percent \\
Up to 2 hectares & 56 \\
From 2 to 5 hectares & 29 \\
5 and above hectares & 15 \\
\hline
\end{tabular}

Source: Federal Bureau of Statistics, Pakistan. Agriculture Census 2000.

Table 5 : $\quad$ Irrigated area

\begin{tabular}{lcc}
\hline & Area & Share of land \\
& Million ha & $\%$ \\
Canal & 3.700 & 56.40 \\
Tube well & 2.740 & 41.77 \\
Others & 0.160 & 2.44 \\
\hline
\end{tabular}

Source: Federal Bureau of Statistics, Pakistan. Agriculture Census 2000.

The farm structure in Punjab is classified into 10 different classes from a farm size of less than 0.5 hectare to above 60 hectares. A large number of farms have landholding less than 2 hectares and account for 56 percent of the total number of farms and own a very small proportion of land which is only 16 percent of the total land area. Only 15 percent of the farms own more than 5 hectares of land and own more than 53 percent of the total land area in the province (FEDERAL BUREAU OF STATISTICS, PAKISTAN, 2000).

Table 6: $\quad$ Farm structure in Pakistani Punjab

\begin{tabular}{lcccc}
\hline Farm size ha & $\begin{array}{c}\text { Number of farms } \\
\text { nos }\end{array}$ & $\begin{array}{c}\text { Farms share } \\
\%\end{array}$ & $\begin{array}{c}\text { Total land area } \\
\text { ha. }\end{array}$ & $\begin{array}{c}\text { Share of land } \\
\%\end{array}$ \\
\hline Under 0.5 & 703,638 & $18 \%$ & 201,112 & $2 \%$ \\
0.5 to under 1 & 617,265 & $16 \%$ & 459,408 & $4 \%$ \\
1 to under 2 & 844,219 & $22 \%$ & $1,166,753$ & $10 \%$ \\
2 to under 3 & 597,863 & $15 \%$ & $1,403,901$ & $12 \%$ \\
3 to under 5 & 536,361 & $14 \%$ & $2,081,497$ & $19 \%$ \\
5 to 10 & 368,362 & $10 \%$ & $2,422,326$ & $22 \%$ \\
10 to 20 & 149,018 & $4 \%$ & $1,858,563$ & $17 \%$ \\
20 to under 40 & 36,696 & $1 \%$ & 909,254 & $8 \%$ \\
40 to under 60 & 5,712 & $0.14 \%$ & 263,095 & $2 \%$ \\
60 and above & 4,932 & $0.12 \%$ & 469,257 & $4 \%$ \\
\hline Total & $3,864,070$ & $100 \%$ & $11,235,161$ & $100 \%$ \\
\hline
\end{tabular}

Source: Federal Bureau of Statistics, Pakistan. Agriculture Census 2000. 
The Punjab province has four distinct climatic seasons which are;

a) Winter season (moderate widespread rainfall) - from December to February.

b) Spring season (moderate) - March -April.

c) Summer season (extremely hot and dry)-May and June which is very hot and humid, scattered rainfall - from July to September.

d) Autumn season (moderate cold and dry) - from October to November.

The annual rainfall in Pakistani Punjab varies from $150 \mathrm{~mm}$ in the south arid regions, 620 $\mathrm{mm}$ in central semi-arid Punjab to $1150 \mathrm{~mm}$ in northern sub-mountainous regions. The seasonal distribution of rainfall is strongly influenced by monsoon, which starts in June and results to more than seventy per cent of the rainfall until September. Winter rains take place during December to March and are more wide-spread. The quantity and distribution of rainfall is normally insufficient for crop requirements in most areas.

The agroecological zones in Punjab are classified into four broad categories which are explained on the basis of crops cultivated, amount of rainfall and other sources of irrigation (PARC, 1987) (figure 2).

Figure 1: $\quad$ Agroecological zones in Punjab ${ }^{3}$

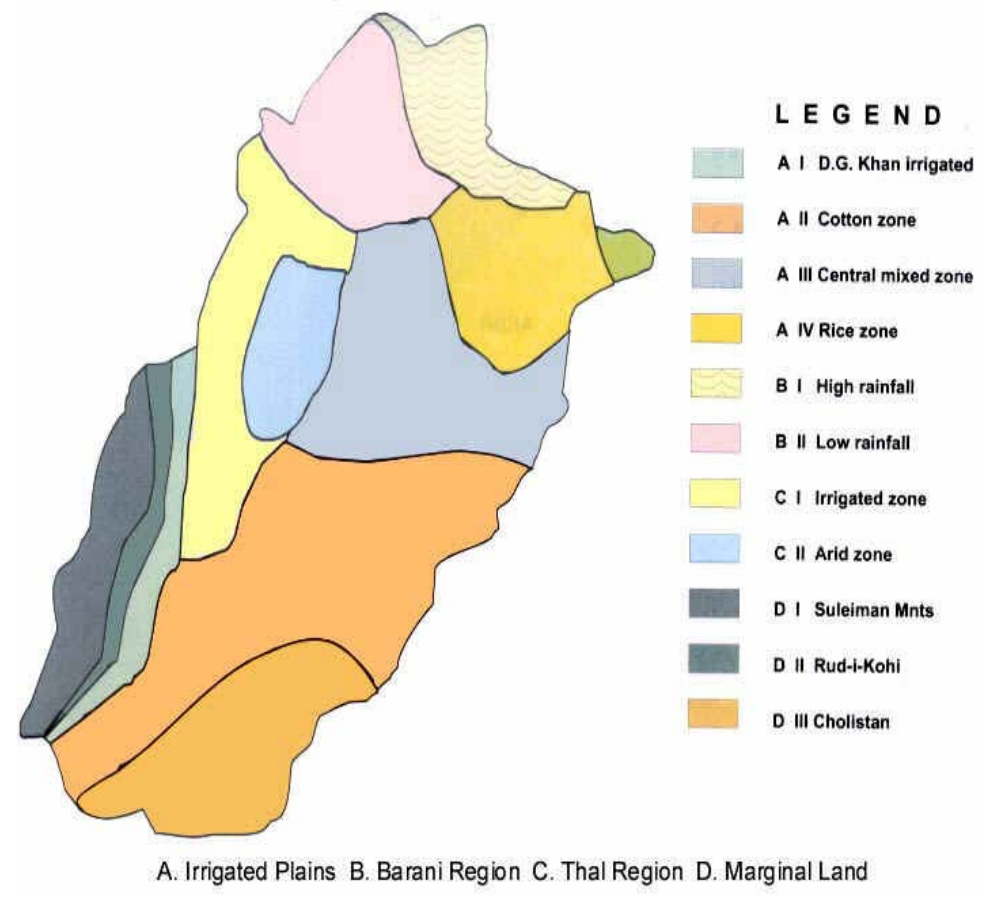


The agriculture production in Punjab is significantly dependent on irrigation water resource that comes from the rivers and distributed through canals and water channels down to the fields. The shortage in canal water is compensated by increased use of ground water through tube wells. Tube-well irrigation covers about 10 million hectares of land in Punjab (PAKISTAN. AGRICULTURE CENSUS, 2000) (see annex 4 for details).

The agriculture production in the Punjab province is classified into four major cropping patterns on the basis of variations in agro-climatic conditions. These production patterns are: (a) cotton-wheat (b) rice-wheat (c) mixed cropping and (d) rain-fed; which corresponds to the Southern, North-Eastern, Central and Northern parts of the province, respectively (AKHTAR et al., 1992).

The major cropping patterns are:-

a) Cotton-wheat cropping pattern: The cotton crop is grown after the wheat crop and is mostly practiced in southern Punjab. This region is not well developed for dairy production. The population of local cows is quite higher but their milk yield is quite low. The share of milk production is about 20 percent to the Punjab's production.

b) Rice-wheat cropping pattern: The rice crop is grown in rotation with wheat crop. This is mostly dominated in canal irrigated region which is north eastern part of the Punjab. The region has more number of dairy animals and contributes up to 30 percent in Punjab's production.

c) Mixed cropping pattern: The crops of rice and cotton are sown in rotation with major crop of wheat. This cropping pattern is practiced more in the central and eastern part of the irrigated region of the province. This region is an important dairy production area in Punjab. The contribution of milk is approximately 40 percent in the total Punjab’s production.

d) Rain-fed: Northern part of Punjab especially the foot hill region (potohar) where agriculture is fully dependent on rainfall. The coarse grains mainly wheat and barley are grown in winter and maize, fodder sorghum are grown in summer. The cow productivity is lower. The contribution in milk production is about 10 percent which is lowest as compared to other regions in Punjab.

The cropping pattern in Pakistani Punjab is dominated by wheat cultivation which is a major staple food. Wheat is grown on 41 percent of the total cropped area followed by cotton, fodder crops and paddy cultivation. The large area under fodder crops shows the importance of dairy and livestock in the Punjab province (table 7). 
Table 7: $\quad$ Percent of land used by different crops in Pakistani Punjab

\begin{tabular}{lc} 
& Percent area \\
Wheat & $41 \%$ \\
Paddy & $11 \%$ \\
Maize & $1 \%$ \\
Pulses & $7 \%$ \\
Oilseeds & $2 \%$ \\
Sugarcane & $3 \%$ \\
Cotton & $15 \%$ \\
Vegetables including onions & $3 \%$ \\
Fruits & $1 \%$ \\
Fodder crops & $14 \%$ \\
\hline Forests & $2 \%$ \\
\hline
\end{tabular}

Source: Federal Bureau of Statistics, Pakistan (2003-04).

\subsubsection{Milk production situation in Punjab}

The province of Punjab is chosen for this study due to its dominance in milk production with 20 million tonnes. It contributes seventy percent to the total milk produced in the country. The milk production of Punjab is almost 1.5 times higher than New Zealand and 2 times higher than The Netherlands (FAO STAT, 2005). For dairy development perspectives, the province of Punjab is better off as compared to other provinces in the country due to substantial number of dairy animals and presence of major milk processing facilities (FAO, 2005; AGRICULTURE STATISTICS OF PAKISATAN, 2003-04).

Milk is an important food component in Punjab. Milk production is centuries old profession of rural communities to raise milk animals. The rural people are used to drink milk together with wheat bread (Chapatti) that provides two third of the daily calories of the body requirement. The agriculture production systems in Punjab favour the milk production in the province. The dairy animals are raised by the farm households as a supplement activity on the farm due to availability of crop residues and by products of main crops that are used as roughages to feed the animals (ALLF, 1997; ZAFAR, 1985; CHEEMA, 1992).

The total population of buffaloes and cattle is 11.28 and 7.45 million heads respectively in Punjab (table 8). This total population includes all milking animals, dry animals, heifers, male and female calves and bulls. More than 95 percent of the cows and buffaloes are kept in rural areas. Only 5 percent of the milk animals are kept in the urban areas on peri-urban farms mainly in the cattle colonies. The cattle include all breeds of cows which are nondescript local cows; Sahiwal cows and crossbred cows. The population of cows and buffa- 
loes is spread all over the Punjab province, but the dominance of buffalo is seen often along the river belts (AHMAD et al., 2000).

Table 8: $\quad$ Punjab cattle and buffalo population 2000

\begin{tabular}{lrrrrrr}
\hline & & Buffaloes & Sahiwal cows & Crossbred cows & $\begin{array}{c}\text { Local breed } / \\
\text { other cows }\end{array}$ & Total cows \\
\hline Rural & no & $10,787,621$ & 326,367 & $1,017,263$ & $5,892,382$ & $7,236,012$ \\
Urban & no & 501,626 & 19,676 & 75,625 & 124,263 & 219,564 \\
\hline Total & no & $11,289,247$ & 346,043 & $1,092,888$ & $6,016,645$ & $7,455,576$ \\
\hline
\end{tabular}

Source: Punjab Livestock Census, 2000.

The buffalo population is more concentrated in upper and eastern part of the Punjab. The over all 86 percent of the total buffalo population is concentrated in 23 districts (see figure 4). The remaining 13.6 percent population exists in eleven districts and one desert region of Cholistan. The eight districts show highest preference of buffalo over cattle. The ratio of these districts in favour of buffaloes against one cow was almost 3 to 1. These preference patterns exist even in crossbred dominated districts of Sialkot 56 percent, Gujranwala 49 percent, Sargodha 46 percent, Mandi Bahuddin 43 percent, etc (AHMAD et al., 2000).

All over Punjab, the buffalo production system is found to be similar (both in buffalo and cattle dominant regions) indicating that they are raised by the farmers in the same manner and for the same purposes and objectives. These similarities are obvious from their distribution comparisons. The existing buffalo production system adopted by livestock owners is solely oriented towards female buffalo as a milking animal.

In all districts buffalo shows more milk production ability than cows, even in districts with higher crossbred cows population .The crossbred cow population varies from 0.2 percent to 56 percent of the total cattle. The highest percentage of crossbred cows is found in Sialkot, Gujranwala and Sargodha district with 56 percent, 49.2 percent, and 46.4 percent of the total cattle population respectively (AHMAD et al., 2000).

Significant differences exist in dairy production under irrigated and non-irrigated-regions (rain fed regions) due to availability of feeding resources. Generally under irrigated region the animals are fed with the green fodder and crop residues while in non irrigated regions the animals are fed with crop stubbles and through grazing on fellow lands. The proportions of availability of feed resources are dependent upon geography, season and land holding (AHMAD et al., 2000). 
Historically milk is produced along the river belts in Punjab. Buffalo population is more dominant in areas around the river belts that accounts for the reason that one of the buffalo breed (Nilli-Ravi) was named after the name of river Ravi that crosses both parts of Punjab i.e. India and Pakistan. The figure 2 shows the areas dominated by buffalo population compared to cows are mainly Lahore, Sheikhupura and Faisalabad.

Figure 2: $\quad$ Map of Punjab province with cows and buffaloes dominance

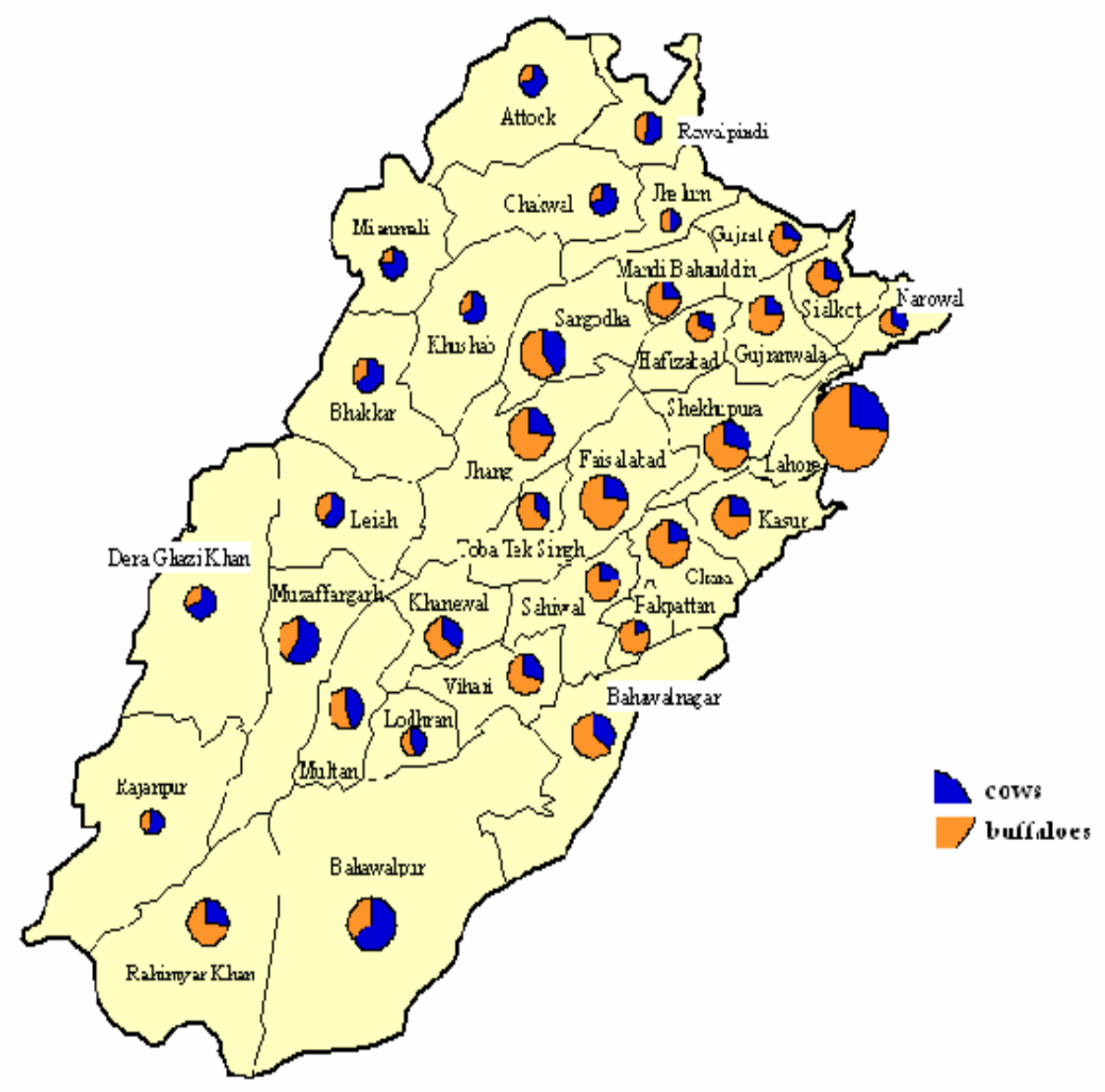

Source: Punjab Livestock Census 2002.

\subsection{Selection of Sargodha District and its Profile}

Out of 34 administrative regions/districts in Punjab, the district Sargodha is selected for this research work of the dissertation due to its importance in milk production. The geographic location of district is important factor behind dominance of milk production in this region. This region is selected as an example of mixed farming system with reference to its significant contribution in milk production in Punjab province (AHMAD et al., 1997). 
Sargodha district has one of the largest herds of milk animals that accounts to about one million cows and buffaloes. The district has largest number of crossbred cows. The crossbred cows show an increasing trend in population and account for 19 percent of the total milking animals. The buffalo population is 59 percent of the total milk animals in the district followed by local non-descript cows (figure 3). Although buffalo is a dominant milking animal but the trend towards raising cows of better genetic potential especially the crossbred cows increased in Punjab during last t two decades. The Sahiwal ${ }^{4}$ cow breed is local zebo type which is disease resistant and high yielding as well as compared to the local cows mostly know as non descript $\left(\operatorname{des}^{5} \mathrm{i}\right)$ cows (AHMAD et al., 2000).

Figure 3: $\quad$ Milking animal types in district Sargodha

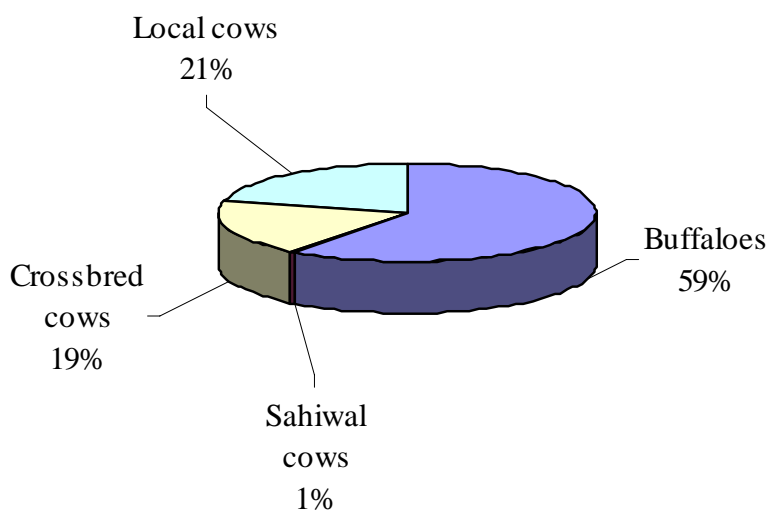

Source: Punjab Livestock Census 2000.

Table 9: $\quad$ Dairy animal's population of district Sargodha ${ }^{6}$

\begin{tabular}{lcccccr}
\hline & Buffaloes & $\begin{array}{c}\text { Sahiwal } \\
\text { cows }\end{array}$ & $\begin{array}{c}\text { Crossbred } \\
\text { cows }\end{array}$ & $\begin{array}{c}\text { Desi / local } \\
\text { cows }\end{array}$ & $\begin{array}{c}\text { Total } \\
\text { cows }\end{array}$ \\
\hline Rural & no & 510,018 & 4,769 & 155,714 & 182,405 & 342,888 \\
Urban & no & 23,586 & 365 & 9,939 & 3,834 & 14,138 \\
\hline Total & no & 533,604 & 5,134 & 165,653 & 186,239 & 357,026 \\
\hline
\end{tabular}

Source: Punjab Livestock Census 2000.

4 Sahiwal cow is a local improved progeny of cows. The breed is resistant against diseases and has better yield as compared to other local cows.

5 Desi /local cattle are non-descript breed which is indigenous breed with low milk yield. These are mostly draught breed.

6 Punjab Livestock census was carried out in 2000 by Punjab Livestock and Dairy Development Department. 
The district Sargodha has always been a centre of various types of agriculture development initiatives carried out by the government, non-government organisations (NGOs) and donor supported programs. For instance, the successful example of "Crop Maximization Program" ${ }^{7}$ initiated under Food and Agriculture Organization (FAO) and Ministry of Food, Agriculture and Livestock (MINFAL) in 1998 that helped to raise the yield level of major crops almost to double at the farm level. Recently another dairy development program has started in Sargodha district together with Punjab government in cooperation with ICARDA $^{8}$.

\subsubsection{Geographical statistics of Sargodha district}

The study area is located in the northeast Punjab, northwest of Lahore (the capital of Punjab) on the Lower Jhelum Canal. It is the divisional head quarter of Sargodha region. The division includes Khushab, Bhakar, Mianwali and Sargodha itself.

Location wise the district has an advantage of better access to the markets (milk processing industry and urban markets) as a result of good connectivity with the major cities of Lahore, Faisalabad, and Islamabad through a motor way M-2 (339 km long) . The district has metalled road length of 1721 kilometres. The city has a rail connection with all the major cities (figure 4).

The district has following five sub regions which are known as tehsiles;

I. Sargodha

II. Bhalwal

III. Sahiwal

IV. Shahpur

V. Sillanwali

$7 \quad$ For enhancing crop productivity, a food security project was started at two locations (Daska and Sargodha) in Punjab in August, 1998. The results were very encouraging, with in two years, the productivity at village level of wheat crop was enhanced by 62.9 percent (from 2.57 tonnes /ha to 4.25 tonnes/ha) at Daska and 70.7 percent (2.9 tonnes/ha to 4.9 tonnes/ha) at Sargodha.

8 International Centre for Agricultural Research in the Dry Areas is CGIAR partner organization and Fodder Research Institute (FRI), Sargodha started a program in 2006 focussing on improving income of dairy and livestock farm households in selected locations. This program started in the end of 2005 under Community Action in Integrated and Market Oriented Feed-Livestock Production Project. The productivity of the dairy animals is generally low in Sargodha district due to poor feeding management, inadequate housing, animal diseases, poor market access, and lack of policy support (ICARDA, 2006). 
The district Sargodha mainly comprises of plain lands and very few small hills on Sargodha Faisalabad road. River Jhelum flows on the western and northern sides and river Chenab on the eastern side of the district. Few areas have severe saline water issue that spoils the land for years e.g. places like kaka, rangpur and laghari. The Jehlum River flows between district Khushab and Sargodha. The organic matter is generally lower than 1 percent and $\mathrm{pH}$ varies between 7.5 to 8 . In some places, the ground water is not of good quality due to higher concentration of insoluble salts and is not suitable for irrigation. Canal irrigation is the main source of water and used as flood irrigation.

The Sargodha city is an agricultural trade hub of the region and is the largest trade centre of agricultural commodities (grains, cotton, citrus fruits, and oilseeds, etc) and livestock markets that fetch traders from the adjacent districts. The main agro based industries are cotton, rice, flour, and oilseed mills besides few engineering plants.

The district has an area of 5,854 square kilometres with a population of 2.6 million inhabitants. The population density is 455 people per square kilometre. About 28 percent of the population lives in urban areas. The literacy rate is better than other rural district which is above 30 percent (POPULATION CENSUS ORGANIZATION, 2002).

Figure 4: $\quad$ Punjab Province map with location of Sargodha district

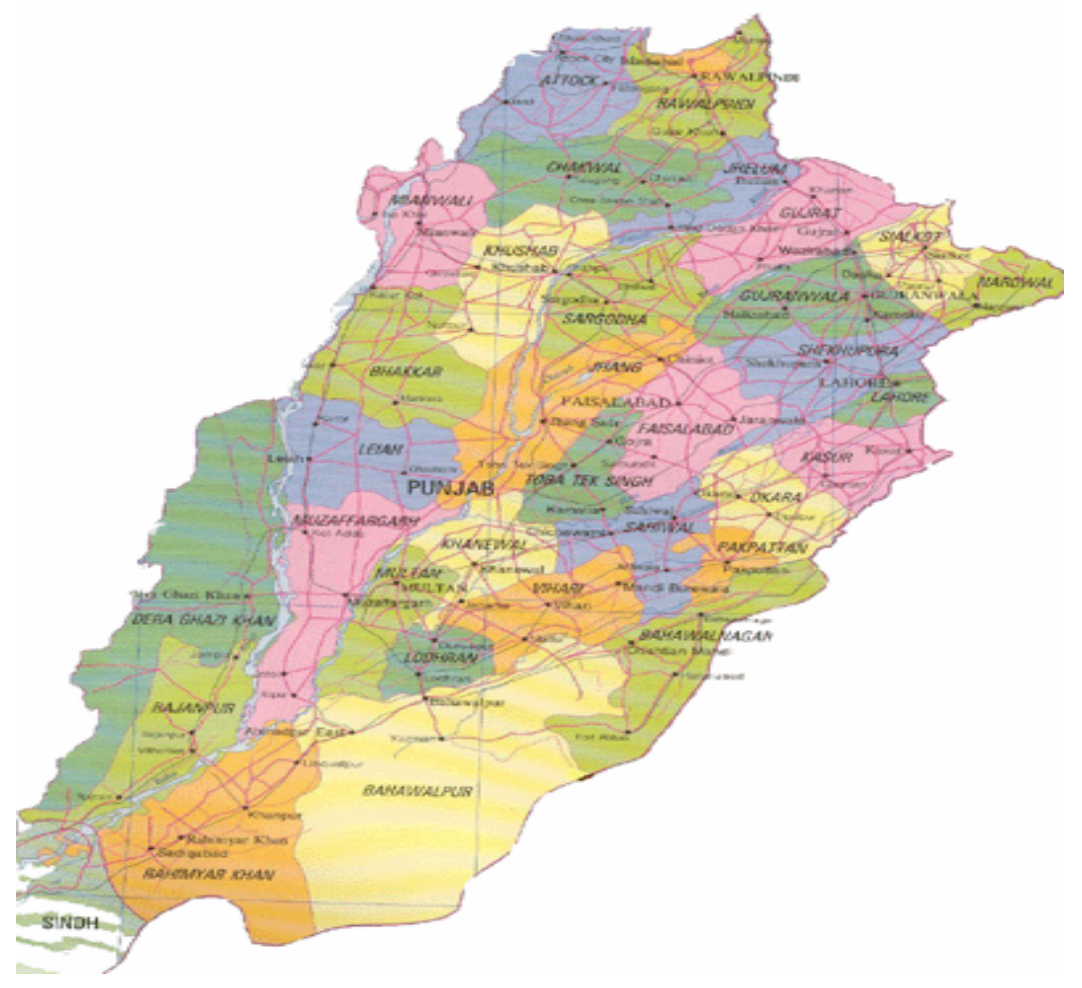

Source: Survey of Pakistan, 2000. 


\subsubsection{Weather data of Sargodha district}

The district has an average rainfall between $400-600 \mathrm{~mm}$ which is not sufficient for crop production and mainly substituted with the canal irrigation. The ground water quality in some parts of the district is not suitable for irrigation and is mostly dependent on canal irrigation.

After considering a four year weather data of district Sargodha from year 1998 -2001, the highest monthly average rainfall was observed during the month of July which was more than $100 \mathrm{~mm}$ followed by higher rainfall in the month of August above $80 \mathrm{~mm}$ (see figure 5 ). The rainy months are very conducive for the fodder production and buffalo calving starts in this period also. The issue of water shortage is partially supplemented with the rains in monsoon month of July and August (figure 5).

The district has both hot and cold climatic conditions in summer and winter seasons. The cold weather is limited to 1-2 months in December and January. The minimum temperature goes below 5 Celsius during January only for a few days. The summer season is long which lasts for 6 months with temperatures above 40 degrees Celsius. The extreme high temperatures of 45 degree Celsius are observed during the months of May and June. (PAKISTAN METROLOGICAL DEPARTMENT, 2001) (see figure 6).

Figure 5: Annual rainfall pattern of Sargodha district

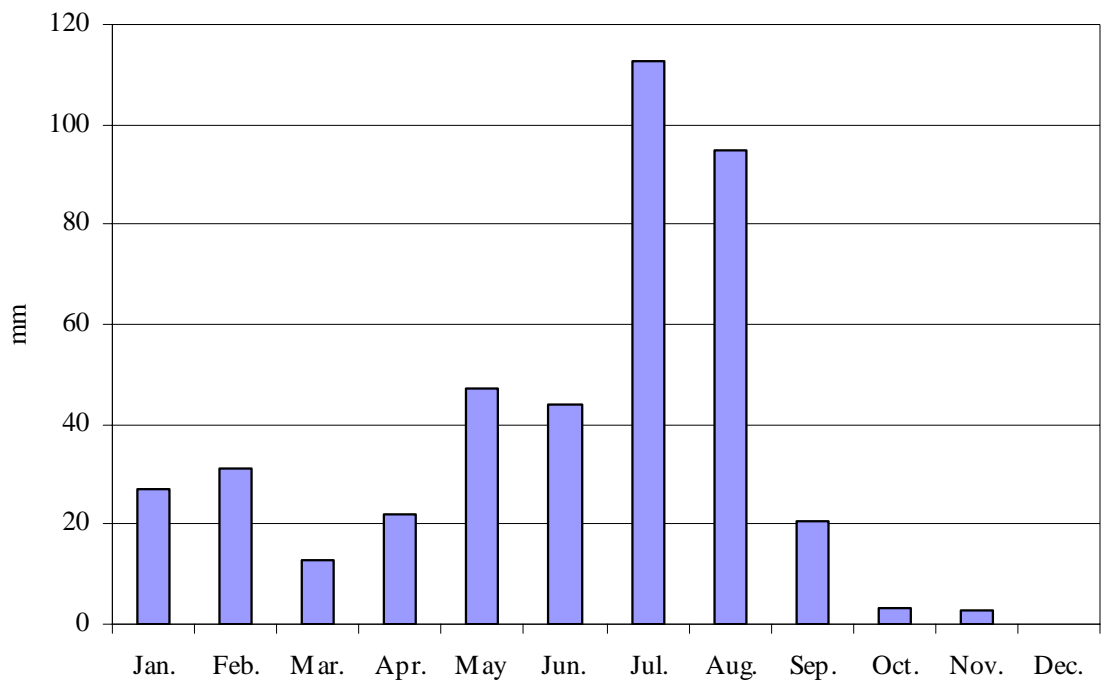

Source: Pakistan Metrological department (4 year avg. from 1998-2001). 
Figure 6: $\quad$ Four years monthly avg. maximum and minimum temperature

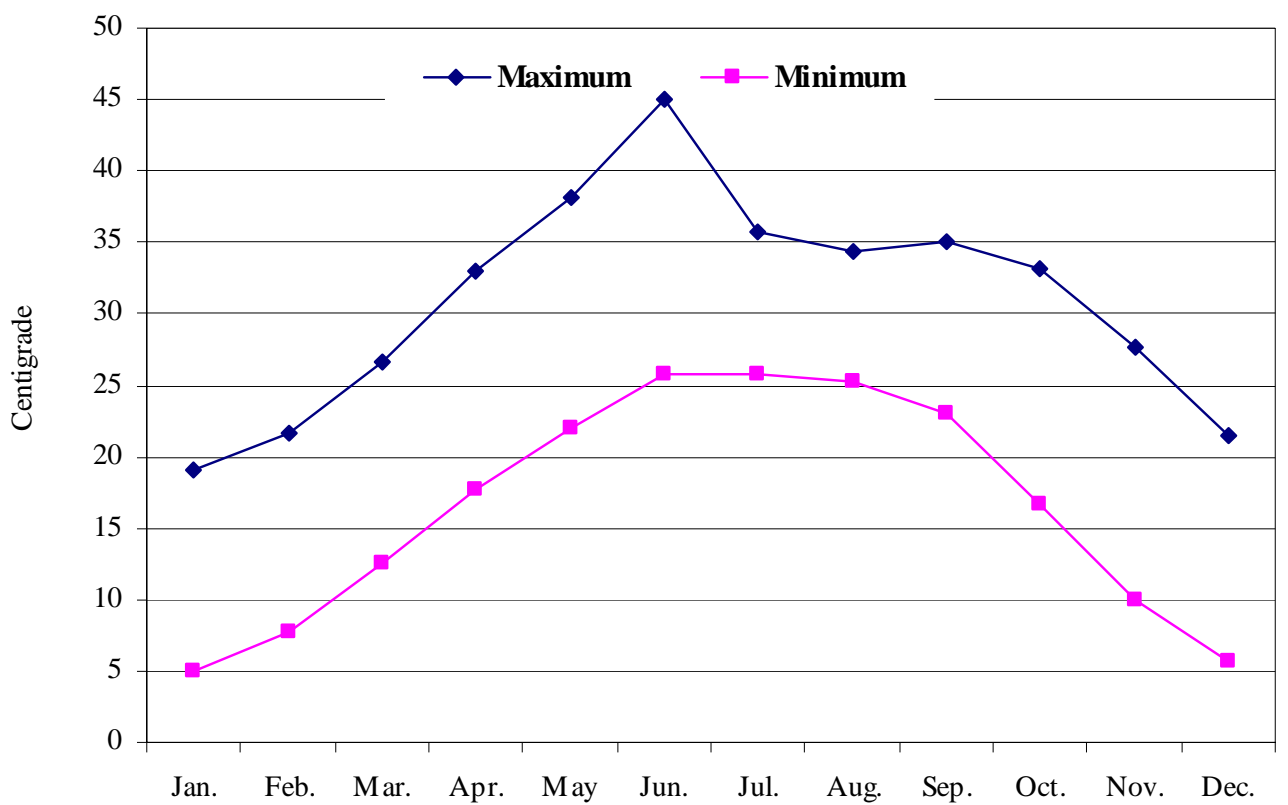

Source: Pakistan Metrological Department (4 year avg. temperature from 1998-2001). 


\section{Method}

The focus of this research work is mainly on the problems concerning current situation of small scale dairy farms in Pakistani Punjab. In spite of their significant role in milk production and over all country's economy, they lack productivities and efficiencies. With their existing farm strategies, they are unable to achieve an income goal to improve their socio-economic conditions.

This chapter therefore elaborates first the literature review on different methods used in the past studies to address the similar problem. Then it explains the procedures adopted for this research work. A stepwise approach is followed by first identifying dairy farm types found in the region through explaining case studies, the actual situation of these farm types regarding milk production and the socio economic situation of the household behind these farm types. It reveals the status quo situation of the farms through selecting typical farm representing each farm type. Finally the typical farm is selected for running improvement interventions and to evaluate the impact of different technology and farm strategies, etc. The results obtained from this research work will be helpful to formulate a frame work for diagnosing similar issues in other parts of Pakistan.

The scientific approach of devising an analytical framework consists of identification of dairy farm types in Punjab. Within Punjab, the irrigated region of mixed cropping system is selected that has a significant share in the total milk production of the province. For this research study, the district Sargodha is selected as a representative of the mixed cropping system under irrigated region. For survey and primary data collection at the micro level, the two villages representing the typical situation of dairying under mixed cropping system are selected. The descriptive analysis of dairy production is carried out. The typical farm types are selected and the real situation is described through cases.

The eventual aim of this research work is to concentrate on the improvement of income from the dairy enterprise; although it is affected by the crops due to dependence for feed resources and competition for getting resources like land, labour and capital. The current research work will span around the dairy enterprise mainly without going into details of other household activities, farm (crop, other farm) and off-farm enterprises, etc.

The sequence of method comprises of analytical framework explaining the data collection procedures, identification of dairy farm types, descriptive analysis of dairy farm types explaining the actual situations of production systems through the case study approach and finally evaluating various development programs/improvement interventions to improve the household income through dairying. 


\subsection{Method Review}

The random sampling procedure was used to select survey households for the cross sectional survey (POATE et al., 1993). The villages were selected from a sampling frame (list of villages) and subsequently households were selected from the selected villages (TEUFEL, 2006). The classification of farm households to generate typologies is the part of extension-orientated researchers, aiming at identifying specific target groups. Qualitative and quantitative methods used for classification of farm households are found in the literature. Qualitative methods are regularly found in French studies, where typologies are iteratively created according to farming activities and functions. One qualitative and one quantitative approach are compared in their ability to characterise the decision-making process in a study on the adoption of a specific agricultural practices in the Ethiopian highlands (DARNHOFER et al., 1997; LANDAIS, 1998; WILLIAMS, 1994).

Various numerical classification procedures to formulate typologies are found in the literature (ALDENDERFER and BLASHFIELD 1984; MOJENA 1977; WARD, 1963; KHAN, 1998). Multiple correspondence analyses were employed, to produce a graphic representation of similarities and difference between households (SOLANO et al., 2000).

F.H. GIDDINGS, a sociologist in the early part of the century, compared the statistical methods to the case study "on the basis that the former are concerned with the distribution of a particular trait, or a small number of traits, in a population, whereas the case study is concerned with the whole variety of traits to be found in a particular instance" (HAMMERSLEY, 1995).

The case study consists of acquiring information by using multiple sources of evidences; surveys, interviews, panel discussions and consulting secondary sources (YIN, 1993). In order to get a simple and understandable solution, the current study adopts the case study approach to understand the status quo situation of dairying farm households, organize them into identical groups and evaluate the impact of appropriate set of farm technologies. For economic analysis of artificial insemination and natural breeding in dairy animals in Faisalabad city, the case study method was used by YOUNAS, 1994.

For a status quo analysis and conducting a policy scenario analysis, the use of typical farm approach is quite effective and reliable. The concept of representative typical farm was created by a panel using a consensus building approach rather than average individual farm data. The concept of panels had proven successful in policy advice since the early 
1980s in USA ${ }^{9}$.This concept is being followed by applied farm economics research in Germany ${ }^{10}$ since 1995 for bench marking and international comparison of farms for policy planning. The use of panels of different sizes is more appropriate technique for setting up a typical farm (DEBLITZ et al., 1998; HEMME, 2000).

The impact assessment of the policy interventions into farming systems can be approached in a variety of ways. A rather simple method is to restrict the evaluation of the intervention's effects to the farming activity concerned by budgeting with one such approach called partial budgeting (NORMAN et al., 1995). Partial budgeting is a method of organising experimental data and information about the cost and benefits from some change made in the technologies that are used on the farm. The aim is to estimate an impact on the farm profit or loss from some change in the farm plan. Partial budgets do not calculate the total income and expenses for each of the alternative plan but list only those items of income and expense that cause the change. They measure changes in income and returns to limited-resources, provide a limited assessment of risk (BOEHLJE and EIDMAN, 1984; MUTSAERS et al., 1986).

Partial budgeting analysis technique is widely used to compare cost of production and revenues at the farm for a new production technology. Quantities of inputs used and outputs obtained, sold and consumed in the households are taken into consideration. With the change in technology or strategy on the farm, a strong impact is seen on the requirements of household's production factors, such as household's labour or self-produced fodder. The limitations of budgeting procedures become apparent due to difficulty in expressing all the factors in monetary terms, it can only be included as budget bases (e.g. return to labour, return to fodder unit), which give several economic values to a proposed intervention (MCCONNEL et al., 1997).

In making the final selection among the interventions, three criteria are considered, firstly, if net income remains the same or decreases, then the new proposed intervention should not be recommended because it does not improve the profitability of the farm, secondly, if net income increases and variable costs remain the same or decrease with the new intervention technology, then this should be recommended because it clearly shows more profitability than the current situation, thirdly if both net income and variable cost increase

9 Used by Agricultural and Food Policy Centre (AFPC) and Food and Agricultural Policy Research Institute (FAPRI) at Texas A\&M University and University of Missouri-Columbia respectively in USA.

10

The concept is widely used by International Farm Comparison Network (IFCN) and Agri Benchmark Project at the Farm Economic Research Institute, Federal Agriculture Research Center, Germany. Agri benchmark is a global network of farm economists generating sustainable, comparable, quantified information about farming systems, their economics, their framework conditions and perspectives world-wide for dairy, arable crop and beef farms (http://www.agribenchmark.org/). 
(that happens in most of the cases), the marginal rate of return is essential to consider. If a strategy produces greater increase in net income and higher marginal rate of return, then this alternative technology is economically more attractive (EHUI et al., 2001).

\subsection{Analytical Framework}

The analytical framework of the current research work is based on status quo analysis of dairying farm households under mixed cropping system in Punjab. It evaluates various interventions to improve the productivity of the most typical farm found in the region to increase the household income through dairying. The farm and households data is collected through a primary survey conducted in the field and the data analysis is carried out using descriptive and quantitative analysis techniques.

The stepwise approach first describes the status quo situation of milk production and household on various farm households through selecting the case study method. The second step of descriptive analysis is used to describe the data sets collected from the surveyed sample. The data set are divided into three groups of farm type's i.e. small, medium and large scale. The third step is comparison of the important parameters observed under each farm type and status quo analysis of farm economics situation through selection of typical farms representing each farm type. The final part is selection of one of the most typical farm type found in the region to evaluate the impact of improvement interventions on household income.

The proposed intervention most probably affect the ratio of factors required, thus require complex changes to the whole production system. The procedures therefore, have been used which manage to simulate the farmers' reaction to an intervention in the way they adopt the allocation of their resources. The method of simple budgeting technique is used for measuring the change in income and benefits due to change in technology. This method is used quite commonly as a farm planning and budgeting tool. All the cost items are added together to account the total production costs. Similarly all the returns and benefits gained as a result of the change in technology are summed together and measured in monetary terms. Partial budgeting is considered as an appropriate tool to measure the impact of a new /changed strategy on the farm income (NORMAN, 1995; WORMAN et al., 1990; DALSTED, 1992) 
Assuming for simplicity that the farmer's objective is to maximise the income from dairy, the method is as follow:

$$
d R=\text { milk receipts }(m R)+\text { livestock sales }(I S)
$$

If returns from milk receipts and livestock sales is total dairy returns $(d R)$

$$
t C=f C+v C
$$

The total costs $(t C)$ included the costs of all the inputs such as feed, non-feed inputs e.g. veterinary costs, wages of hired labour, represented as variable costs $(v C)$ and fixed costs $(f C)$, etc. Fixed costs represent the costs that do not vary when comparing alternative technologies (e.g. land). Variable costs are those that do vary between the technologies, such as the amount of feed or labour used, etc.

$$
n I=d R-t C
$$

The net income $(\mathrm{n} I)$ is calculated after deducting the total costs $(t C)$ from total dairy returns $(d R)$.

In deciding whether or not to adopt a new technology, a farmer will ask if it will increase his or her income. Similarly in order to properly screen among alternative interventions/ technologies for further evaluation, this study will investigate if the intervention is potentially economical and more attractive. If the $f C$ is equal to zero because by definition fixed costs do not vary. Assuming that capital is not a constraint, the intervention with the highest $n I$ will be recommended. However, higher benefits may not be attractive if they require very high costs. New technologies typically require a package of increased inputs (thus additional costs). As a result the farm will incur new costs and returns that have to be considered in making a decision. Thus, it is necessary to compare the extra costs with the additional benefits.

\subsubsection{Selection of study area}

The Pakistani Punjab is selected for this research study due to its importance in milk production in the country and the significance of the study to serve as a model that can be replicated in the other regions of the country. For any work to serve as a model it is necessary to be a representative of one region. Punjab is the largest province in terms of milk production and consumption (60 percent of the country's population lives in this province). The Punjab province has diverse agro-climatic zones that affect the cropping patterns in this region. Out of four cropping patterns only the mixed cropping system is selected. It contributes up to 40 percent of milk production in the Punjab Province (AHMAD et al., 2000). Under the mixed cropping system, there are various administrative 
regions that are called districts. Within these various districts, Sargodha is selected as a study district due to its relevance to the research subject (see details in section 2.3)

\subsubsection{Selection of villages}

The selection of villages plays an important role in collection of relevant data to be used for micro analysis of the households' social structure and farm production economics in the context of research objectives. With this consideration in mind two villages are selected which have variation in production and households assets, consumption patterns and market participation to carry out a quantitative analysis. The villages which have large number of small scale farms and are engaged in dairy activities are important for the survey point of view for this research work. The selected villages are chak no. 74 SB and chak no. 105 SB. Data is collected randomly from different farm types from each village.

The selection of these two villages satisfied the criterion to some extent. For status quo analysis of the dairy production patterns in the region, the selected villages are found to be suitable. For both of the villages dairy and livestock activities are an important source of household's income. Dairy production is carried out in the backyard as a typical pattern in Punjab (KUROSAKI, 1998).

Rapid Assessment Procedures (RAPs) and Rapid Rural Appraisal (RRA) are followed to describe the actual situation of the villages. RRA is a development-planning tool, which involves outside experts guided by local communities in data collection and development of plans and PRA are outside experts empowering local people to do their own data collection and plan development and implementation. RAPs and RRA are used to accumulate relevant and accurate information. Both procedures are quick and cost effective to collect a data (GRANDSTAFF, 1985).

The selected villages have fertile land and access to sweet water resources through canal or tube well irrigation to grow fodder crops besides the main activity of cash crops production. The sweet water mainly comes through the canal south branch Sargodha. The ground water quality is not good in village 105 SB and water table is quite high. At times of heavy rains, sometimes the water table comes up to 2 feet which is not good for crop production and secondly also the seepage of the distributor canals becomes an issue during monsoon season.

The soils are characterised as moderately coarse to medium coarse and their quality is moderately higher towards saline in village 105 SB and slightly saline in village 74 SB. The cropping pattern of the villages is more or less following the same pattern found under mixed cropping system. 
The social structure of the selected villages is quite homogenous in population, caste structure, ${ }^{11}$ and land holding/tenancy system. Both the villages of 74 SB and 105 SB are comprised of 517 and 397 farm households respectively (table 10). More than 70 percent of them are engaged in raising dairy and livestock animals. The land operating classes are jaat, arian, ranja castes.

Table 10: General description of the villages

\begin{tabular}{lcccc}
\hline Village & $\begin{array}{c}\text { Number of farm } \\
\text { households(nos) }\end{array}$ & $\begin{array}{c}\text { Total agri. land } \\
\text { (acres) }\end{array}$ & $\begin{array}{c}\text { Dairying } \\
\text { households(nos) }\end{array}$ & $\begin{array}{c}\text { dairying share } \\
\%\end{array}$ \\
\hline 74 SB & 517 & 1,500 & 412 & $79.6 \%$ \\
$105 \mathrm{SB}$ & 397 & 1,000 & 301 & $75.8 \%$ \\
\hline
\end{tabular}

Source: Farm household of the villages, * hhs = households.

Majority of the farms in the villages are operated by the land owners themselves. There are few farm households in the villages work as owner cum tenants. The large owners have either shifted to the towns and have rented out land or are engaged in other off-farm activities. The state owned land in the villages is leased out to the farmers.

The selected villages are located within the radius of $25 \mathrm{~km}$ from the urban centre of Sargodha city. One village (74 SB) is located in the North of the city in Bhalwal direction and it is connected through a paved road. The individual farms are connected to the village and road through un-pave roads. On average the distance of individual farms varies between 0.5 to $2 \mathrm{~km}$.

The village $105 \mathrm{SB}$ is located in the South of Sargodha city in the direction of Chiniot city. It is connected through a paved road of about $8 \mathrm{~km}$ to the main road and then $2 \mathrm{~km}$ of unpaved (see figure 7). 
Figure 7: $\quad$ Location of the selected villages

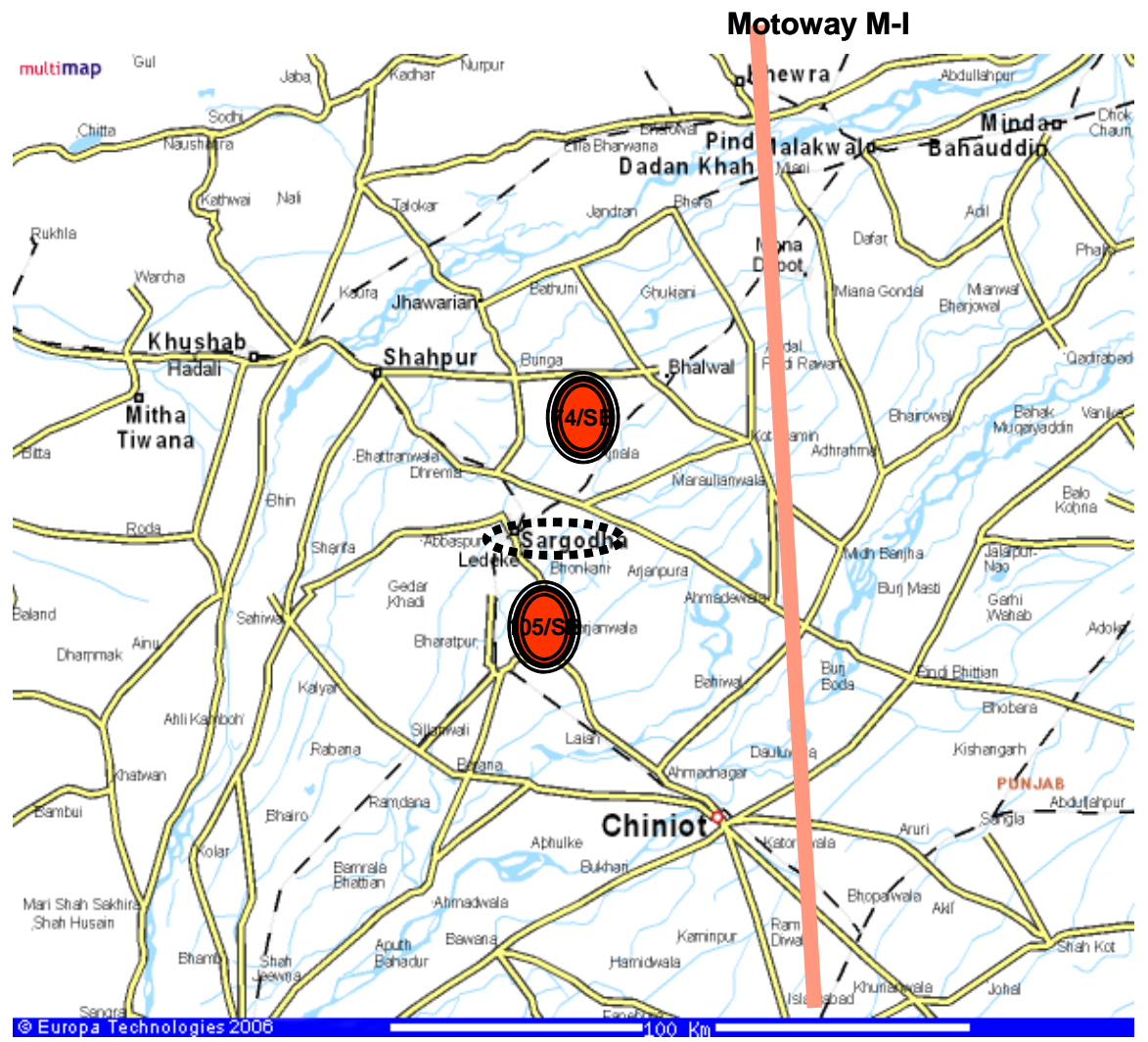

Source: Author's own illustrations to show the villages and motorway with the map and taken from Europa technologies (2006) from internet.

After getting into the village, the rapid appraisal approach focused mainly on the following questions:

- $\quad$ Number of household living in each village.

- Dairy farm types and its farm structure (land holding, number of animals, etc).

- Home consumption and sales of milk.

- $\quad$ The major issues associated with the dairy in terms of low productivity.

\subsubsection{Selection of sample size}

The selection of appropriate sample size is always essential depending on type of method to be used for later on analysis. To meet the demand of data collection, large sample size was a constraint in terms of time and resources. Therefore, the survey sample was specifically selected to ensure that all characteristics of farm types were included properly. The objective of this study is to understand the milk production on the farm through descrip- 
tive analysis. A sample size of 36 farm households is selected for this study. The sample size comprised of 24 farm households from village 74 SB and 12 from village 105 SB.

The data collection team comprised of four persons including the author to conduct the primary survey. The procedure adopted in data collection was personal interviews, panel discussions to consolidate and verify data sets.

For this study, direct interviewing method is used for panel discussions and to fill in the questionnaires. The interviews of the respondents are conducted in two stages. The first stage is necessary to build a trust relationship with the respondents by informing them about the objectives of the research study. In the second stage, the respondents are asked direct and indirect questions related to household's income, farm inputs, outputs, etc. The pertinent questions are asked in a sequence to get a thorough inside knowledge of the situation. Open-ended questions are asked to verify the validity of the long list of general statements as well as their representation by fewer independent statements. All the answers and feedback are well documented with descriptive and quantitative features.

After sample selection, a complete enumeration of selected farm households was done through using two types of questionnaires. The questionnaires were filled in during the panel discussion and individual farmer interviews. Later on the data was entered into $M S$ Excel format.

These questionnaires used for data collection are as under;

\section{a) General questionnaire}

It is used to collect data on the general farm household's attributes (demographics, resources, and the income proportion coming from the off-farm and farm enterprises). The questionnaire is designed in a way that most relevant information about the farm households, general farm, dairy and crop are collected in a comprehensive manner. Various types of direct and indirect questions were asked to verify the information through panel discussions.

\section{b) Detailed farm data questionnaire}

It is used to gather in-depth information about the farm enterprises, the input costs and returns. The data is collected for household living expense, resources (land, labour, capital). Since the major focus is dairy enterprise, only thorough information is collected from the dairy enterprise. The data of dairy enterprise includes the data on the number of milk animals with milk yields, milk fat, protein contents, lactation period, dry period, inter calving intervals, the variable and fixed costs, the feed requirement per animal (ration), feed costs, milk prices and meat prices, etc. (see annex 16 for details). 


\subsubsection{Selection of the farm households}

As a pre-requisite of the study, only those farm households are selected that have land for growing fodder and are engaged in dairy farming activities. The data is collected from 36 farm households from the two villages regardless of their farm size. The variables used for data collection mainly cover the households and farm attributes related to dairying. The data collected from farm households includes information on,

I. Family size, number of male members, number of female members, number of children, age of the farmer, experience of the farmer, education of the farmer, etc.

II. Farm resources, land (owned and rented land), labour (family labour, hired labour), value of farm machinery, etc.

III. The area under various crops in summer and winter and calculate the yields and returns for each crop in a year.

IV. The income from dairy and livestock production (daily milk produced, milk sold, home consumption, price of cows and buffaloes milk, milk yield, meat prices, livestock prices, etc.).

V. Other farm income (from selling goats, chicken, etc.).

VI. The qualitative data on farm location, distance from the road, and distance from the milk collection centre, etc.

\subsection{Case Study Approach}

Theoretically, the case study method is used to organize a wide range of information about a situation and then analyse the contents by seeking patterns and themes in the data and by further analysis through cross comparison with other cases. Unlike more statisticallybased studies which search for quantitative data, the goal of a case study is to describe the real situation. It is a written description of a problem or a situation. This method provides opportunity to sharpen the problem solving skills of the decision makers (YIN, 1993; STAKE, 1995).

The case study method is chosen as an appropriate technique for detailed examination about what happens in the dairying household to understand the milk production system under mixed cropping system in Sargodha region. The selection of one case study is done very carefully from each farm type to explain the real situation of milk production. 
Three case studies ${ }^{12}$ are selected representing each farm type to describe the actual situation of the farm households involved in dairying. They are designed in a descriptive way so that all the details of the farm household and farm inputs and outputs are covered. The assumptions are adopted to calculate the whole production year (January to December) with both production seasons i.e. autumn /winter sowing (Rabi) and spring/ summer sowings (Kharif).

\subsection{Selection of Typical Farm}

The typical farm concept is used in this study to get a reliable data about the typical farm situation of milk production in the region. A panel of local farmers and extension agents are formed together to develop three typical farms based on the different farm types found in the area. This approach is helpful to create a representative farm type that is recognizable and relevant for each panel and the typical farm in that region, while preserving a high degree of anonymity of the farm panelists. The panel approach proved very useful to define a farm type closer to reality. This approach is widely used in USA for policy advice since 1980’s (DEBLITZ et al., 1998) and in Germany since 1995. ${ }^{13}$

The verification of representative farm data is carried out together with the farm panelists. Upon initial data collection, panelists are required to review and verify input data and result outputs. This method verified that the results of the analysis work in a consistent manner according to the local conditions.

The main criteria considered in the selection of the three typical farms were: (a) results of descriptive analysis used to observe different farm household, (b) co-operative attitude of farmers to share information on the production and cost items of the whole farm and households on memory recall basis; (c) trust of the respondents gained to draw appropriate responses for sensitive data on farm income, investments and expenditures.

\section{Assumptions}

The status quo analysis is carried out to understand the households' economic situation and share of dairy income in the household income. The gross margin analysis of the farm enterprises is carried out by calculating returns and costs.

12 The case studies are designed in consultation with the researchers of Fodder Research Institute (FRI) Sargodha, coordinator of ICARDA project and the extension agents working in the region.

13 This typical farm approach is used by IFCN (International farm comparison network) active in dairy competitiveness studies in Germany and worldwide and by Agri Benchmark concept developed by Professor Dr. Folkhard Isermeyer for policy analysis in crops and livestock farms in Germany 
The current study used some key assumptions for the calculation of the costs and returns. The objective of these calculations is to estimate the individual returns from all the farm enterprises to calculate the overall household income. Result outputs are created to show the contribution of each enterprise. The analysis covers the whole financial year from January to December. The crop production costs and returns are calculated for both the summer and winter crops. The economic analysis of typical farm is done to produce the gross margins after allocating all the costs and returns to various components.

The household net income is calculated by adding together the contribution of different enterprises to household income. The household income is interpreted in the form of income per capita per day. The per capita income per day is calculated by dividing the net household income with the adult man equivalent of the family members ${ }^{14}$. This output is later on used to compare the income from various improvement scenarios. (GARCIA et al., 2003)

The household income equation is as following;

Households net income $=$ Net Off-farm income (from off-farm enterprises + salary from employment $)+$ net income from all farm enterprises (crop + dairy + other farm).

\section{Net farm income calculations}

The net farm income calculation was done on annual basis and the equation looked like as,

Net farm income $=$ Revenues from all enterprises sales $($ crop + dairy + other farm enterprises).

+ Value of non-cash outputs (home consumption).

+ Revenue from livestock sales (cull cows, calves, mature heifers, etc.).

+ Revenue from other dairy income (sale of manure+ draught power sale).

- Expenses incurred on crop production (seed+ fertilizer+ seedbed preparation + irrigation + pesticides + harvesting, etc).

$14 \quad$ All the family members are standardized into man equivalent by using the standard adult man equivalent standards which are adult man $(>18)$ is equal to 1 , adult woman $(>18)=0.92$, old age parents $(>$ $65)=0.80$, children $(14-18$ year $)=0.85$, children $($ under 14 year $)=0.25$ (BRADSHAW J and MILLAR J, 1991). 
- Expenses on dairy production includes the variable costs (cost of forage production + feed + health + water + milking + cost of fodder purchase+ breeding, etc.).

- Total farm depreciation.

- $\quad$ Total interest liabilities.

- $\quad$ Land rents.

- $\quad$ Expenses of hired labour.

\section{Off-farm income}

Off-farm income is the gross margin of the entire off-farm enterprises. The gross margin is calculated after deducting the total input costs from the total returns.

\section{Herd size}

The farm is assumed to be constant in whole one year. Sale and purchase of animals are not considered.

\section{Calves rearing}

The calves reared on the farm are not part of the dairy farm income but are part of the other farm. So the cost incurred on feeding and management goes to the other farm.

\section{Annual milk production of the whole herd}

Generally the entire herd is not in milk production round the year in a farm and all the cows do not calve all of a sudden in January and go dry in December rather the calving takes place round the year. The method quoted in literature takes certain percentage of wet animals which is on an average seventy percent of the milking animals (TEUFEL, 2002). This average dry herd percentage is calculated by deducting the wet percentage separately for the cows and buffaloes for their life time productivity.

Dry animal percentage $=$ dry days in productive life times/lactation days in productive life time. 


\section{Milk yield per animal per year}

The farms in the study area lack milk recording system. It is very difficult to calculate the milk yield per lactation. The milk yield per lactation ${ }^{15}$ is calculated by asking the farmers about the peak, middle and lowest milk yields during the entire lactation period. At the end, the milk produced in various months of lactation is summed up to calculate the milk yield per lactation (table 11).

Table 11: Example of milk yield calculation ${ }^{16}$ per lactation

\begin{tabular}{llcc}
\hline & & Cows & Buffaloes \\
\hline First 3 months milk x 2 times a day & kg/day & 6.0 & 6.0 \\
Second 3 months milk x 2 times a day & kg/day & 6.0 & 5.0 \\
Last 3 months milk x 2 times a day & kg/day & 4.0 & 4.0 \\
\hline Milk yield per lactation & kg/lact. & 1,440 & 1,350 \\
\hline
\end{tabular}

Source: Household survey.

\section{Average annual milk yield}

The average annual milk yield per animal is necessary to calculate the returns and costs per year. As the lactation of some animals overlaps to the next year so a standard method used to calculate milk yield per animal per year is as under,

Annual milk yield $(\mathrm{kg})$ per year =lactation yield $(\mathrm{kg}) /$ (lactation days +dry days) $x 365$ days.

\section{Milk standardization - energy corrected milk (ECM)}

There are two different types of milk that comes from cows and buffaloes with different compositions. The standard method of energy corrected milk (ECM) developed by international dairy federation (IDF) and widely used by IFCN dairy is used ${ }^{17}$ for presenting milk outputs.

The cow milk has 3.5 percent fat, 3.9 percent protein and buffalo milk has 6 percent fat and 4.5 percent protein contents. 
ECM milk $=(($ total marketable milk production $\times 0.383 \times$ milk fat in percent $)+($ total marketable milk production $\times 0.242 \times$ milk protein in percent) + (total marketable milk production $x$ 0.7832)) /3.1138.

\section{Capital costs}

The owned capital in the form of fixed assets, machinery and equipments is used for dairying with out the value of land considered as capital. For equity 3 percent and for liabilities 6 percent interest rates are used in the analysis. This reflected the method of “capital using costs” developed by ISERMEYER, 1987.

\section{Opportunity cost}

The opportunity cost is considered for non cash cost mainly for the family labour and owned capital. The local wage rate is considered as the opportunity cost of the family labour and calculated separately for women, children and adult males. It is finally calculated into adult man equivalent.

\section{Depreciation}

Machinery and building are depreciated by use of a straight-line schedule on purchase price with a salvage value of zero.

\section{Milk returns}

Milk returns are calculated based on the average milk prices received throughout the year (including the summer peaks and winter fall off) adjusted to volume of milk in ECM.

\section{Non milk returns}

The livestock sales of mainly the cull cows, male calves and surplus heifers are finally added into milk returns.

\section{Non cash benefits}

The non-cash benefits of dairy are from home consumption of milk, use of dung cakes as fuel for cooking food and farmyard manure used in the fields. All the non-cash outputs are given the market prices. The value of farm outputs that are consumed by the farm households and hired workers without compensating the business in cash should be added to farm revenues. (IAEA, 2000). ${ }^{18}$ 


\section{Costs and returns}

Calculation of precise costs and returns of milk production on a mixed farm having crops and dairy and other enterprises is a complex issue. Especially with family owned farms like in most of the other developing countries, it is hard to find record on the farms in Pakistan.

The costs are estimated realistically to determine the gross margin. The major costs components of the dairy farm are feeding costs, animal husbandry, veterinary care and management costs, milking and handling costs, etc. The feeding costs include the cost of forage production from owned land or rented lands. This can also include the purchased green fodder and concentrate items. Normally the total costs include all the cash and noncash costs, depreciation, interest on fixed capital and opportunity of owned resources (land, labour and capital). Dairy is only responsible for costs and returns from calves until they are sold at an early age less than one year. The returns from calves sale at early ages goes to dairy enterprise.

\subsection{Intervention Scenario Evaluation}

The final aim of the current research study is the evaluation of improvement interventions to increase household income of the most typical farm found under the mixed cropping system in Punjab. The improvement through productivity enhancement of the farm types would have significant impact on milk production and income of the farm households involved .The improvement interventions are identified by gathering ideas from literature and expert opinion.

The improvements are evaluated on one typical farm type which is a small farm type initially used for this study. The existing farm is considered as a baseline and improvement is projected on same farm type through ex-ante simulation. The differences between existing farm situation (baseline) and the post intervention situation are compared. Initially, combining gross margins into a whole farm budget will help to give some indication of the effects of interventions (UPTON, 1996).

The improvement in income situation of the dairying household from adoption of various scenarios is compared. The farm household's income is transformed into income per capita per day. Later on it is used to compare with the minimum living standard of international poverty line, US\$ 1 per capita per day (World Bank, 2004; GARCIA et al., 2006). 
After the description of the major farm types and explanations through the case studies, a set of issues are pointed out which are concerned with low productivity of animals i.e. lower milk yields per year, lack of efficiency in utilization of production factors, differences in prices of milk sold by different farm types, etc.

Similarly the experts opinion based on the knowledge and experience also suggest various possibilities that can help to improve the productivity and finally the income of household's. How to overcome these issues will help to improve the productivity of the farm. These issues can be resolved by adopting various improvement interventions.

From a long list of possible options for improvement in animal productivity and increasing dairy income, only a few are short-listed and grouped into two major categories which are production and marketing improvement. The production improvement is subdivided into four categories which are feeding, husbandry, health and breeding.

The improvements are compared in terms of household income before and after introduction through ex-ante assessment. All related costs and differences caused by the intervention are measured accordingly. The ex-ante analysis is applied to measure the effects of proposed interventions with additional adjustments causing extra costs and returns .The simple method to restrict the evaluation of the interventions is the static analysis by the use of partial budgeting method (NORMAN et al., 1995).

It is observed from the literature and later on through survey that the dairy farms face issue in appropriate nutrition availability. There is an annual deficit of 29 percent total digestible nutrients (TDN) and 56 percent digestible crude protein (DCP) in Pakistan to feed animals. The gap between supply and demand increases due to increasing competition for grains and fodder for feeding humans and animals. The present feed resources permit animals to achieve only 75 to 80 percent of their inherent productive capacity (CROWDER, 1988).

In general, the green fodder and roughages are the major source of energy to fulfil the body requirements of dairy animals under mixed cropping system in Punjab. Dry fodder is mainly the wheat and rice straw. The silage making is not practiced while feeding green fodder is widely used. The shortage of fodder results into seasonality of milk production on the farm. The small scale farms suffer a lot under these circumstances. Under the existing system the dairy farms face the shortage of fodder production in summer and winter. Since most of the small farms cannot afford to buy expensive ration or feed grains, they rely mostly on the availability of green fodder and roughages. The traditional fodder crop varieties lack the potential to increase yield per acre. There is a need to introduce new varieties of fodder crops that can produce better yields and can overcome the fodder shortage. 
HUSSAIN et al., (1993) reported that fodder oats harvested at various intervals produced more fodder yields and less crude protein with plant age/early crop maturity. The crop should be harvested at a stage that provides an optimum compromise between forage yield and quality. Maximum green fodder, dry matter yields and crude protein contents were recorded when oat crop was harvested at 50 percent flowering. The oat performs better and provides multiple cuts, tiller profusely and yield more, and is of higher nutritional value. A major reason is that the standing oat crop can be harvested progressively, free land earlier than normal for follow-up crops or relay cropping. Later in the season, any remaining part of the crop can be harvested at the farmer's discretion and dried as hay. This coincides with optimum soil moisture for land cultivation and planting of the following crop. This also allows small areas or peripheral lines on terraces to be saved for seed production. In many, but not all instances, more recently bred cultivars out-yield older ones (DOST et al., 1997).

After discussion with the researchers from the Fodder Research Institute(FRI), Sargodha and ex-post analysis of the progressive large farms in the region, it is suggested that new fodder cultivar of Oat (Avena Sativa) show a significant improvement in yield as compared to traditional winter fodder of berseem. Oat fodder is selected as feed improvement intervention during the winter period. Oat is considered as major forage among the green forage and hay in the urban markets for feeding urban dairy farms. Oat can provide a high quality feed to the animals and can produce high yields at the farm. It performs better at lower temperatures than berseem fodder and is helpful to provide feed in the winter time when there is shortage of fodder and prices are high (DOST, 1997).

The summer fodder crop of hybrid sweet sorghum (Sorghum Sudanese) is considered to show better results as compared to traditional fodder crops grown in the area. Hybrid sorghum has attained popularity in the last many years in Pakistan. It can be harvested 3-4 times in the warm season if irrigation is provided on regular intervals and fertilizer is applied when required. The sweet sorghum is a better feed, with little danger of toxicity than ordinary sorghum. The local varieties of sorghum do not produce high yields. The imported seed with hybrid characteristics is appropriate to produce higher yields. The seed prices are higher for hybrid sorghum and costs can be compensated through higher yields (DOST, 1997).

The nutrients and yield of both new fodder crops are evaluated economically for their impact on milk. The impacts of yields achieved per acre are calculated. Similarly, the extra costs require buying improved seeds and other inputs are also taken into account. The input costs are mainly seed, fertilizer, agronomy and irrigation related items, etc. There is a wide gap between the current milk yield of herd per year and the potential. On average the milk yield of small farm types is one third of the potential yield per year that can be achieved by making appropriate changes in husbandry practices. 
The major factor behind low yield of the herd is the very high age at first calving i.e.36 to 45 months for local cows and buffaloes respectively under mixed farming system. The inter calving intervals are exceeding beyond 18 months on most of the farms. The dry periods are going beyond 150 days. The annual milk yield increases proportionately to the reduction in inter-calving period. The breed potential of most of the milking herd in Pakistan is generally very low. They are mostly dual purpose breeds raised for meat purpose or used for performing various farm operations in the past. The widely used natural methods have poor selection of bulls without any progeny testing records. The milk yield of dairy animals can be increased to double or more through use of selective breeding through artificial insemination. By adopting specific husbandry measures mainly focussing on good feed and appropriate health management, by giving attention to the oestrus cycle and timely impregnating the animals, the calving interval can be reduced. The inter-calving interval can be reduced by 14 percent in cows and 16 percent in buffaloes. By adopting such husbandry measures the farm can overcome the issue of longer dry periods and help to produce more milk per year that will improve the household income as a whole (AHMAD, 2000; TEUFEL, 2006).

Marketing is a serious constraint faced by rural farmers of all sizes. The small farms suffer a lot due to limitation of getting lower prices. The small scale farms mostly face problem in selling their milk due to lack of bargaining power with the formal buyers. They get less than 50 percent share of the price paid by the consumers. The milk is sold to the middlemen buying milk from the villages and sell in the towns.

The marketing scenario proposes a high milk price strategy according to which the small scale farmers will be able to sell their milk on higher prices either through direct marketing in the nearest town of Sargodha or have an easy access to a milk cooling centre of a formal market buyer (milk companies like Nestle is already active in a few areas). The extra costs on transportation are deducted and even then it shows better improvement in gaining farm households income.

\section{Constraints}

In general this research work faced the issue of access to the quality data of farm households. During the course of time various challenges were faced especially in data collection, analysis and validation later on.

The farm data about production parameters, costs and returns are the most difficult part to verify in small scale and family farms. There is hardly any concept of book keeping on the small scale and even large farms in Pakistan. This proved to be a very critical issue to determine the real costs and returns. As a general custom, the farming communities always tend to project production costs higher and the outputs / returns lower. The author has overcome this situation through panel discussions and cross-questioning during survey. 
Milk yield is another issue where documented information not available on a farm. The only option is to trust the memory of the farmer by asking him the milk yield at various stages of lactation, e.g. first three months, middle three months and last three months. Sometimes a technique of repeated questioning is used to confirm the answer by floating a question to a group of farmers at a time and reaching a consensus.

In general, the rural farmers are afraid to share correct information due to fear of new taxes or fees from the government. This issue is overcome by involving the local extension agents from Fodder Research Institute who have already mobilized most of the farmers about the survey and importance of data accuracy. They therefore feel comfortable in sharing their personal information.

The current study used the simple approach of descriptive analysis to identify farm types. The typical farms are selected based on the empirical analysis. The method used the partial budgeting technique for evaluation of the impact of various interventions.

In performing partial budgeting it is very much important to keep track of costs and benefits accurately. This requires: (i) appropriate quantification of the production parameters; (ii) correct use of inputs consumed, and outputs produced; and (iii) calculating inputs and outputs in monetary terms. All other non-cash costs (e.g. family labour, capital cost and depreciation charges) need to be valued carefully. Non-market inputs and costs are valued through use of opportunity cost but it needs more careful thinking.

But at the same time the partial budgeting may indicate that the new technology is "better" than the traditional one but it will not show that both technologies produce a loss. Although a partial budget is easier to interpret but not often presented with a statement of the farmer's objectives, the farmer's resource base, and important non-cash consideration. Sometimes the partial budget over looks the availability of labour on the farm to perform new proposed interventions. It ignores the ability to substitute the inputs and how they are allocated based on fixed costs and the implicit prices of the resources. Therefore the result of partial budgeting shall be treated with caution.

Valuation of the home consumption is another difficult part for that a proper determination method needs to be adopted to avoid overestimation or underestimation of costs and returns. 


\section{Results and Discussion}

The results of the study are presented in the sequence of descriptive and quantitative analyses of farm types found in the region and are discussed in sequence of status quo analysis through case studies, results of farm survey and situation of typical farms. The final part of the results describes the impact of various improvement interventions.

The status quo analysis of dairying farm households is done through adopting descriptive analysis of the data collected from farm households in Sargodha region under mixed cropping system. Three case studies are selected to describe the physical and functional attributes of the most common farm types found in the region. The classification cross-sectional data is carried out on the basis of the total cultivated land. The farm types are grouped into three types which are Group I, small-scale, Group II, medium scale and Group III, large scale farm types.

One case study representing the particular farm type is selected and presented thoroughly to understand the farm households and dairy farm situation in the region. The explanations are followed by the illustration of the figures found in survey. The results of the survey of farm types are presented in the form of mean, standard deviation, minimum and maximum values observed for the key variables. Later on one typical farm is defined representing each group to explain the key production and economic parameters of farm households and milk production. Analyses of the typical farms lay a foundation for the next step for analysis of improvement interventions.

This procedure is repeated subsequently for group II and group III farm types. Later on the cross sectional comparison of the findings is carried out through explaining the distinct features of the groups through tables, figures and text description.

The final part of the result chapter elaborates the improvement interventions through explanations of certain assumptions applied. It explains the impact of interventions on milk production of the farm that ultimately helps to raise the income level of the farm households. All of the costs and returns are calculated by using the partial budgeting technique. The result of impact of each intervention is presented in the form of tables and text explanations. The input costs and outputs are compared with the status quo situation of the typical farm type PU-3 and the ex-ante situation of PU-3 after intervention. The final comparison is made for the key selected outputs of all the four interventions on milk production increase and household's income.

\section{Descriptive analysis}

Based on the data sets collected from a sample size of 36 farm households from two villages in Sargodha district, both the quantitative and qualitative analysis techniques are ap- 
plied to identify various farm types. The data sets showed a wide range of variability in cultivated land, number of milk animals, feeding, husbandry and management practices, etc. The criterion of landholding (both owned and rented) is used to define the groups found in the survey. The data collected from the farm households is divided into three major groups which are; Group I, small scale farm type, Group II, medium scale farm type and Group III, large scale farm type. The explanations of the key characteristics of farm types are helpful to understand the current situation of milk production in the study region.

On the basis of classification 58 percent of the farm households come under group 1 small scale farm types, 28 percent under group 2 medium scale farm types and 14 percent under group 3 large scale farm types. Overall the small scale farm types dominate in the region with a farm size of 1 to 10 acres land found in the sample (table 12).

Table 12: Grouping of the sample farm types

\begin{tabular}{lcc}
\hline Farm types & $\begin{array}{c}\text { Farm size } \\
\text { landholding }\end{array}$ & $\begin{array}{c}\text { No of houshold } \\
\text { nos }\end{array}$ \\
\hline 1. Small scale farm types & 1 to 10 acres & 21 \\
2. Medium scale farm types & 10 to 20 acres & 10 \\
3. Large scale farm types & above 20 acres & 5 \\
\hline \multicolumn{2}{c}{ Total surveyed dairying farm households } & 36 \\
\hline
\end{tabular}

Source: Results of farm household's survey.

\subsection{Group I, Small-scale Farm Type}

The Group I, small-scale farm type has a land holding of 1 to 10 acres. The characteristics of small scale farm types are explained through three steps with the sequence of case study, results of statistical analysis of the survey showing mean, standard deviation, minimum and maximum values of the key selected variables and finally with the selection of a typical farm showing the key production and economic outputs of farm households and milk production in the region.

\subsubsection{A case study of small-scale farm}

The case study method is selected to describe the situation of milk production on a small scale farm type under mixed cropping system observed in Sargodha region. It describes the situation of a farm household by answering questions pertaining to the demographic of the household, allocation of resources among various enterprises, income generation pat- 
terns, etc. The case study explains the outcome of key farm operations performed on the farm. It narrates the socio-economic situation of the farm households and the living conditions.

To obtain all the details, one farm household that comes under small scale category is cho$\operatorname{sen}^{19}$ for this case study. Mr. Aftab Ahmad is a farmer and the head of the family living in the village of $105 \mathrm{SB}^{20}$ in Sargodha region.

\section{General farm details}

The farm has a land holding of 3 acres (1.21 ha) ${ }^{21}$ which is all self owned. All the land is canal irrigated and used for growing crops. The soils are sandy loam with higher proportion of salts. Crop farming is the main activity of the farm. Dairy is a supplement activity on the farm with 3 milking animals. Two of the milking animals are local buffaloes and one is a local cow (non-descript type).

\section{Household profile}

The farmer is 40 years old. He has attained primary education (attended 5 years of school). He adopted agriculture as a full time profession by working on the farm with his father in 1980. The farmer is married and has three children. He lives together with his wife and children along with parents under a joint family system in village 105 SB. The family comprises of 7 members altogether. The family demographics are two adult males, two adult females and three children (2 males, 1 female). Out of three children, two attend school located in the same village. As a local norm, generally the women do not work in the fields. The women mostly stay at home and are involved in carrying out household chores which are mainly preparation of meals for the family, cleaning of house, washing clothes and taking care of children, etc. They are also involved in handling the milk in house, mainly boiling and preparing various home products which are mainly butter oil (desi ghee) and butter milk (lassi), etc.

\section{Off-farm income}

The family has an off-farm income source generated by the off-farm employment of the eldest son. The eldest son of the farmer is 17 years old and has passed middle school certificate (8 years schooling). He works as a helper in a machinery repair workshop closer to

19 Farmer is interviewed on his farm early in the morning.

20. The village is connected via a paved road (made of bricks), which links the metal road that joins the main highway connecting Sargodha with Faisalabad city. The distance between the village and the metal road is approximately $1 \mathrm{~km}$.

21

One hectare is equal to 2.47 acres. 
the village. His annual income is about Rs 24000. The off-farm income provides a contribution to meet the family living expenses.

\section{Crop farming}

Crop farming is the main activity on the farm to grow grains for home consumption and to sell surplus. The by products of the crops are used for feeding animals. Wheat is the major crop in winter season grown on an area of 0.8 ha. About 1 ton of wheat is used for home consumption. The wheat grain is used as a staple food to make bread for feeding the family. The surplus of 1.3 tonnes of wheat grain is sold in the market at a price of Rs 350 per $40 \mathrm{~kg}$ to a local grain agent.

As a rule of thumb, an equal amount of wheat straw is produced like the grain. The wheat straw is used to feed dairy animals. The wheat straw has a market price of Rs 30 per $40 \mathrm{~kg}$ at the time of harvest. Sugar cane is the second major crop standing round the year and is grown on a small area of 0.2 ha. The sugar cane is harvested between the months of December and March and sold to a sugar factory at the purchase centre situated closer to the village. The sugar cane yield is about 70 tonnes per ha per year. The cane is sold at a price of Rs 60 per $40 \mathrm{~kg}$.

The sugar cane leaves and tops are removed before selling it to the sugar factory. Both the leaves and tops are used as roughage to feed the dairy animals during the winter season. The farmer grows maize crop in spring during the months of March and April on an area of 0.4 ha. The spring corn yield is about 2 tonnes per ha. The corn is sold in the local market at a price of Rs 350 per $40 \mathrm{~kg}$. The stalks left after removing the cobs are harvested and are fed as green fodder to the dairy animals. The farmer grows basmati rice on 0.4 ha. He gets an overall production of 0.8 tonnes of rice, out of which 0.6 tonnes are sold in the market and rest 0.3 tonnes are used for home consumption.

The farmer grows two types of winter fodder crops which are berseem (Trifolium alexandrianum) and lucern (alfa alfa) on an area of 0.2 ha. As a practice, the farmer sows some mustard in the berseem fields that is used as a fodder and few plants are not harvested that are kept for flowering which are harvested later on to get grains. The harvested mustard is used for oil extraction which is mainly used for home consumption. The berseem fodder is harvested four to five times in a season (produces multi-cuts). The average forage yield of 30 tonnes per ha is produced. The green forage is chopped into small pieces and mixed with wheat straw to feed the animals.

The farmer grows the summer fodder of local sorghum variety and millets on fields free from winter fodder on an area of 0.2 ha. The average foliage yield of summer fodder is 20 tonnes per ha. 
The farm suffers from shortage of fodder during winter and summer months due to lack of rains and irrigation water that effects the fodder production in the region.

\section{Dairy farming}

The dairy herd of this farm consists of 5 animals that include 3 milking animals, 2 calves and 1 heifer. The dairy animals are mainly buffaloes (two) of indigenous breed and one local cow (non-descript type). The buffalo breed is Nilli Ravi. The buffaloes and cows are hand milked twice a day in early and middle stage of lactation. Only in the last stage of lactation, the buffaloes are milked once a day or on alternate days. The average milk yield per lactation is low as $993 \mathrm{~kg}$ for cows and 1,265 kg milk for buffaloes.

The farmer raises the female calves to grow them as heifers, while the male calves are sold within one year. The heifers are used for replacement of low yielding animals. Sometimes the farmer sells the milk animals to fulfill emergency cash needs of the family. These are mainly related to health and family issues. The dry period of the milking animals is quite high on the farm which goes beyond 24 months.

The farmer practices the natural mating methods (with bulls) which are relatively cheaper and even freely available from a neighbouring farm but the results are not attractive due to lack of genetic potential of the breeding bull The farmer does not have direct access to the artificial insemination services mainly due to lack of timely availability of the service and secondly higher costs involved.

Figure 8: $\quad$ Small-scale case study farm

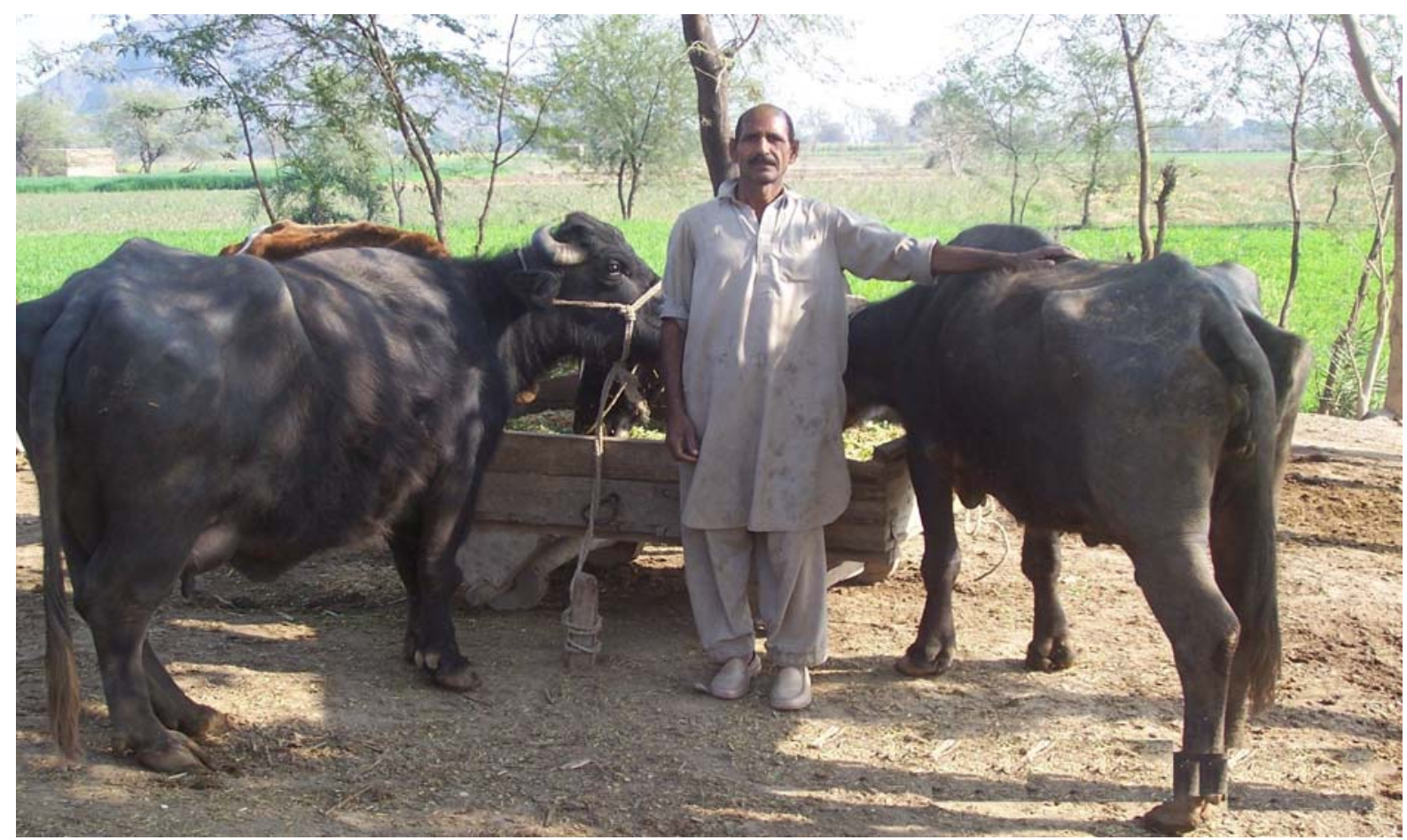




\section{Feeding management}

The animals are typically fed with wheat straw, sugar cane tops and dry leaves, rice hay mixed with the green fodder etc. At times of fodder shortage, the animals are only fed with wheat straw. Concentrate feeding is almost not practiced on this farm due to lower milk yields and lack of resources to buy costly feed items. The health condition of the animals is very poor. In general the feed resources available on the farm are inadequate. The animals are under nourished that is one of the reasons of lower productivity.

\section{Animal housing}

The building structure of the farm is substandard and made of mud and straw thatched roof. The floor does not have any bricks and is similar to an open paddock. This farm has two sheds consisting of a large shed (20ft x12ft) and a smaller one (10ft x12ft). The large one is used for housing adult animals. The smaller shed is used for housing heifers and keeping the fodder chopping machine. The animals have ropes/chains around their necks which are tied to the wooden pegs dug in the ground around the feeding mangers.

The manure is stored as such after collecting from the animals in the shape of a pile near the sheds. The manure is used as farm yard manure once in a year. The manure is also used to prepare cow dung cakes which after drying are used as fuel. The farmer does not sell the farm yard manure and spreads it in the fields.

The housing condition of the farm affects the health and productive performance of the animals especially the calves which are sensitive and more prone to diseases as their immunity level is low. Due to exposure to extreme climatic conditions such as extreme heat and extreme cold, the animals go under stress. Ultimately the farm suffers from poor performance of milking animals on one hand and on the other hand experiences higher mortality rate especially for calves.

\section{Farm machinery}

The farmer has not made a significant capital investment in the farm machinery and equipment. He owns a few machinery items which are fodder chopper with a small diesel engine (3 horsepower) and 3 wooden mangers for feeding animals and a hand water pump to lift water from the under ground. The farm has a donkey cart that is mainly used for transporting the fodder and goods on the farm. Further equipments are three milk buckets, two spades and five steel chains to tie the animals. The farm does not have a tractor for tillage operations and gets all the ploughing and other operations on rental basis from other large farmers of the village. 


\section{Management and labour}

All operations on the dairy farm and the crop farm are carried out by family labour. The owner works full time on the farm. The old parents also support work on the farm mainly for cutting fodder and feeding animals. The women work at home to handle the liquid milk to process it into various cottage products used for home consumption. They perform various functions related to dairying by handling milk. The children work part time on the farm mainly in the dairy enterprise in the evening, weekends and also during the summer vacation. They help in feeding animals and bringing animals to the water source, etc.

\section{Dairy income}

The income from dairy mainly comes from the sale of milk and sale of meat animals which are male calves and cull cows. This farm sells about $4 \mathrm{~kg}$ milk daily and keeps about $3.5 \mathrm{~kg}$ milk for home consumption. This way, the farm sells almost 60 percent of its total production. The milk is sold to a local milkman (dhodi) who collects milk every morning. The milk is sold on one to four weeks credit to the milkman. Most of the morning milk is sold and only evening milk is used for home consumption. The price of milk received by farmer is Rs 12 per kg for cow milk and Rs 17 per kg for buffalo milk during the winter times. The milk prices are higher in summer which is Rs 13 and Rs 19 per $\mathrm{kg}$ for cows and buffaloes milk respectively. The total annual income from dairy enterprise is about Rs 50,000 which includes about Rs 30,000 from sale of milk and Rs 20,000 from sale of meat animals.

\section{Discussion}

The case study reveals that dairy plays a significant role in small scale farm types which have marginal household income. The sale of milk generates income for the family. It acts as source of subsistence to sustain the household income. The emergency needs of the cash requirement are fulfilled through sale of livestock animals. Milk and livestock sales contribute significant share in overall household income. The share of income from crops is insignificant due to small size of land holding. The farmer has enough availability of family labour to work on the farm. They do not have any other alternate source of employment (KUROSAKI, 1995; FISCHER, 2000).

The total milk consumed in the household is mainly used as liquid milk and for preparation of dairy products which are butter oil (desi ghee), butter milk (lassi), etc. The dependence of dairying households on purchased vegetable oil is reduced. The advantage of processing milk into butter oil (ghee) helps to increase the shelf life of dairy products and sell surplus to generate income for the family (JOST, 1980).

The issue of balanced nutrition is very common in small scale farms. This hampers the dairy productivity.The farm suffers from shortage of green fodder during the months of 
extreme weather conditions both in summer and winter months. The gap in fodder supply is fulfilled through buying green fodder from other farmers or feeding poor quality roughage (only some straw). Due to poor feeding the animals do not have good health. The major reasons behind low yield of animals are the poor genetic potential of the animals and lack of proper husbandry management, etc. The improvement interventions focusing on these issues can help to overcome the low dairy productivity of the animals and increase the household.

\subsubsection{Survey results of group I: small-scale farm type}

The survey results are presented in a sequence to show the variability within the farm group to understand the situation of farm household's production and consumption pattern. The actual situation is explained in a case study and later typical farm is selected for economic analysis of milk production. Some of the key results of the survey are presented here as mean, standard deviation, minimum and maximum values observed in the sample population.

The surveyed farm households showed a mean of 10 persons living per family on small scale farm types. In terms of adult-male equivalent units the average size of the family is 8.2. On average 3.1 adult males are found in each farm household. The presence of more males is considered as more work force that means more income for the family (table 13).

The education level is observed to be very low in small scale farm types which are somehow correlated with the socio-economic status of the farm households. Poor farm households cannot bear the expenses of school rather engage them at an early age to work on the farm. This is the reason that literacy rate has remained lower in this region (less than 40 percent). The average years of school attendance are 4.4 years (table 14) .But this trend is changing slowly as there are more education opportunities coming up in the rural areas through the free government and non government programs. These programs focus more on the education of children especially the female education.

Table 13: Family demographics

\begin{tabular}{lcccrr}
\hline & Mean & $\begin{array}{c}\text { Standard } \\
\text { Deviation }\end{array}$ & Min & Max \\
\hline Family size & nos & 10.57 & 7.47 & 4 & 37 \\
Adult male & nos & 3.14 & 1.96 & 1 & 9 \\
Adult female & nos & 2.67 & 1.52 & 1 & 8 \\
\hline Children & nos & 5.00 & 4.81 & 0 & 20 \\
\hline
\end{tabular}

Source: Results of farm household's survey. 
Table 14: $\quad$ Farm manager's profile

\begin{tabular}{lcccrr}
\hline & & Mean & $\begin{array}{c}\text { Standard } \\
\text { Deviation }\end{array}$ & Min & Max \\
\hline Farm manager's age & years & 49.76 & 15.84 & 23 & 80 \\
Experience & years & 31.43 & 17.77 & 6 & 70 \\
\hline School attended & years & 4.43 & 4.28 & 0 & 12 \\
\hline
\end{tabular}

Source: Results of farm household's survey.

The income pattern of the farm households under small scale farm types show that an average 38 percent income comes from dairy enterprise. The share of off-farm income is on average 22 percent. The crop income share on average is 36 percent in the household income. Few farms have other farm income which is on average 6 percent of the total household income (table 15).

Table 15: $\quad$ Farm household's income situation

\begin{tabular}{llccrr}
\hline & & Mean & $\begin{array}{c}\text { Standard } \\
\text { Deviation }\end{array}$ & Min & Max \\
\hline Farm households income & Rs/year & 91,106 & 44,727 & 38,400 & 200,550 \\
Off-farm income & Rs/year & 19,800 & 36,792 & 0 & 144,000 \\
Income from dairy & Rs/year & 34,228 & 27,047 & 8,760 & 120,450 \\
Crop Income & Rs/year & 3,245 & 14,563 & 5,250 & 63,000 \\
\hline Other farm income livestock & Rs/year & 5,571 & 10,303 & 0 & 36,000 \\
\hline
\end{tabular}

Source: Results of farm household's survey.

The farm structure of small size farm type shows that they have an average land holding of 4 acres (1.6 ha.) with a standard deviation of 2 acres. There are landless farms in the region but for research reasons they are not selected for this study. Land is a limiting factor for small scale farms to produce cash crops and grow fodder to feed animals. In that case they generally rely on rented land. On average the rented land is 1 acre. More than 65 percent cultivated area is allocated to cash crops and 30 percent used to grow fodder crops for the animals.

The small scale farms have lower capital investment in farm machinery and equipment. The major farm machinery items are fodder chopper, feeding mangers and milking equipment which are buckets, etc. The small scale farm type does not own any tractor or other farm implements. It is mainly due to lack of capital available and more dependence on manual labour. 
The small farm types have traditional housing system of small sheds made of mud and thatched roof tops. Generally the housing conditions of the animals are very poor and lack protection against harsh weather conditions. The farm sheds are not capable to house animals round the year and are only used by animals for three months during winter season. They are mainly used to store wheat straw and other farm produce during rest of the year (table 16).

Table 16: Landholding and farm capital

\begin{tabular}{|c|c|c|c|c|c|}
\hline & & Mean & $\begin{array}{l}\text { Standard } \\
\text { Deviation }\end{array}$ & Min & Max \\
\hline Total land & acres & 4 & 2 & 1 & 8 \\
\hline Owned land & acres & 3 & 2 & - & 7 \\
\hline Rented Land & acres & 1 & 2 & - & 5 \\
\hline Area for cash crops & acres & 3 & 1 & - & 6 \\
\hline Area for fodder crops & acres & 1 & 1 & 0.25 & 3 \\
\hline Share of area under cash crops & $\%$ & $66 \%$ & $22 \%$ & $0 \%$ & $88 \%$ \\
\hline Share of area under fodder & $\%$ & $29 \%$ & $17 \%$ & $0 \%$ & $80 \%$ \\
\hline Value of farm equipment & Rs & 23,350 & 19,888 & 5,000 & 75,000 \\
\hline Value of farm buildings & Rs & 52,471 & 17,710 & 27,000 & 95,000 \\
\hline
\end{tabular}

Source: Results of farm household's survey.

The labour requirement of small scale farms are mostly met through the family labour. Generally, the farm does not hire labour due to sufficient availability of its own family labour. Only sometimes if necessary a part time worker is hired (table 17).

Table 17: $\quad$ Farm labour requirements

\begin{tabular}{lcccrrr}
\hline & & Mean & $\begin{array}{c}\text { Standard } \\
\text { Deviation }\end{array}$ & Min & Max \\
\hline Family labour & hours/year & 4,784 & 2,294 & 730 & 9,760 \\
Hired labour & hours/year & 13.50 & 52.37 & 0 & 240 \\
\hline Family labour share & $\%$ & $99 \%$ & $5 \%$ & $75 \%$ & $100 \%$ \\
\hline
\end{tabular}

Source: Results of farm household's survey.

The average herd size of small scale farm type is 7 animals that include all the milking and dry animals, calves and bulls. The number of milk animals on average is 3.5 heads with a standard deviation of 1.94. The number of milk animals among the sample population varies from 1 to 9 . On average 63 percent milk animals are buffaloes and only 27 per cent are cows. The buffalo is a major milk producing animal that dominates small scale farms. The milk yield varies from 782 to $2255 \mathrm{~kg}$ per year with an average of $1675 \mathrm{~kg}$ per 
year. The milk yield is lower mainly due to poor genetic potential, lack of proper feeding, animal husbandry and veterinary care (table 18).

Table 18: $\quad$ Dairy production details

\begin{tabular}{llcrrr}
\hline & Mean & $\begin{array}{c}\text { Standard } \\
\text { Deviation }\end{array}$ & Min & Max \\
\hline Herd size & nos & 7.29 & 3.73 & 2 & 18 \\
Milking Animals & nos & 3.52 & 1.94 & 1 & 9 \\
Buffaloes & nos & 2.14 & 1.52 & 0 & 6 \\
Buffaloes share & $\%$ & $63 \%$ & $29 \%$ & $0 \%$ & $100 \%$ \\
Milk yield per animal & kg/year & $1,674.8$ & 433.7 & 0 & 2,555 \\
Cows & nos & 1.45 & 1.12 & 1 & 5 \\
Calves & nos & 2.15 & 1.01 & 0 & 4 \\
\hline Heifers & nos & 1.62 & 0.95 & \multirow{2}{*}{0} \\
\hline
\end{tabular}

Source: Results of farm household's survey.

The average milk produced per day is $11 \mathrm{~kg}$ with a standard deviation of 6.5. The daily milk production volume varies from 4 to $36 \mathrm{~kg}$ per day. The average milk sales are about 40 percent that goes up to 60 percent in some cases. Rest of the milk is consumed at home as liquid milk for family consumption and processed into different cottage dairy products like butter oil, yogurt and butter milk, etc.

The prices of the buffaloes and cows milk differ mainly due to variations in the fat contents in the milk. The acceptability of thicker milk due to higher fat contents is widely popular for home consumption and fetches higher prices. The buffalo's milk price is about $30 \%$ higher as compared to cow milk prices due to higher fat contents (table 19).

Table 19: Milk sales and home consumption

\begin{tabular}{llrrrr}
\hline & & Mean & $\begin{array}{c}\text { Standard } \\
\text { Deviation }\end{array}$ & Min & Max \\
\hline Milk produced & $\mathrm{kg} / \mathrm{day}$ & 11.13 & 6.51 & 4 & 36 \\
Milk sales volume & $\mathrm{kg}$ & 4.38 & 3.73 & 1 & 20 \\
Home consumption & $\mathrm{kg} / \mathrm{day}$ & 16.02 & 0.88 & 18 & 16 \\
Share of milk sales & $\%$ & $39 \%$ & $12 \%$ & $17 \%$ & 20 \\
Price of Buffalo milk & Rs/kg & 18.57 & 1.79 & 12 & 15 \\
\hline Price of cow milk & Rs/kg & 13.48 & 1.14 & & 12 \\
\hline
\end{tabular}

Source: Results of farm household's survey. 


\subsubsection{Typical farm-PU3}

The typical farm under small scale farm type is formed after looking at the survey results and the expert opinion of the farm panelists. PU-3 is identified as the typical farm under small scale farm type. This farm is typical in the region. The cultivated land of the farm is 3 acres. The typical farm has 3 milking animals with majority of buffaloes breed. The animals are fed with green fodder and the by products of the crops i.e. wheat, rice straw and sugar cane tops. The concentrate feeding is not practiced on this farm. The share of milk and livestock sales is significant in over all household income. The milk yields are low as 1170 and $1350 \mathrm{~kg}^{22}$ per lactation for buffaloes and cows respectively. The home consumption of dairy is about 41 percent. The share of dairy income in the overall household income is 40 percent. The economic parameters of milk production and net household income of PU-3 typical farm are described later on in the section 4.4.2 of this chapter.

\subsection{Group II, Medium Size Farm}

The Group II, medium scale farm types have land holding of more than 10 acres and less than 20 acres. The land holding includes both the owned and rented land. The situation of milk production and the farm households are explained in three steps with the sequence of case study, presenting key results of the survey showing mean, standard deviation, minimum and maximum and finally with the selection of a typical farm showing the key production and economic outputs of farm households and milk production.

\subsubsection{A case study of medium size farm type}

The case study method is selected to describe the situation of milk production on medium size farm type under mixed farming system found in Punjab. It describes the real situation of a household and farm by answering questions pertaining to demographics of the farm households involved, allocation of resources among various enterprises, income generation patterns, etc. 
One farm household under medium scale category is chosen ${ }^{23}$ from the study area. Mr. Arshad Zaman is selected for this case study. The farmer lives in the village of $105 \mathrm{SB}^{24}$ in Sargodha region. The discussion with this farmer helped to understand the milk production system. All the farm planning and management strategies were discussed in detail to get the farmer's point of view.

\section{General farm details}

The farm has about 16 acres of arable land. The farmer has rented in about 8 acres from a neighbouring farm on share cropping ${ }^{25}$ basis from another farmer who has migrated to the town. The farmstead is located in the green fields and the farmer's residence is in the village which is about $2 \mathrm{~km}$ distance apart.

He grows wheat as a winter crop on an area of 8 acres. He keeps a milking herd of 6 animals with 4 buffaloes, 2 crossbred cows.

\section{Household profile}

The farmer is 46 years old. He is married and does not have children. He lives with his wife. He is retired army personnel. The farmer has got an intermediate diploma education from the nearest town of Sargodha (12 years of schooling). After retirement he adopted farming as a profession since 2001 and has now become a full time farmer. The farmer is relatively well off economically and has got a concrete house in the village.

\section{Off-farm income}

The farmer has made a significant investment in off-farm enterprise where he owns two tractors and loader trolleys. They are used to extend rental services in the nearest town of Sargodha for construction materials. The average income from tractor rental is about Rs 30,000 per month. The farmer has purchased these tractors through a bank loan and pays back the loan in yearly installments. The loan installments will be finished in 7 years time,

23 Farmer was interviewed at his house at daytime and later on the same evening was interviewed on his farm.

24 The village is connected through a paved road (made of bricks), which links the metal road that joins the main highway connecting Sargodha with Faisalabad city. The distance between the village and the metal road is approximately $1 \mathrm{~km}$.

Share cropping is widely practiced phenomenon in irrigated Punjab, the land is rented to a tenant on share basis which means that tenant will apply all the seed and other inputs and put his time to grow a crop. The owner of the land will share the cost of seed and fertilizer at the end. He will share the half production from the farm. The share cropping system is still very common in the irrigated Punjab. Where the tenant and the land owner share the input costs and similarly they share the output of the crop grown, the management of the farm is with the tenant. Normally the calculations of the output are made at the time of harvesting of each crop. e.g. 2 tonnes wheat is produced per ha. After deducting the input costs, the grain is divided equally among the tenant and the land owner. 
out of which he has already paid the loan for 2 years. The farmer has provided his land to the bank as collateral and pays an interest rate of 12 percent per annum.

\section{Crop farming}

The farmer grows the major crop of wheat on an area of about 8 acres. The farmer gets about 4.9 tonnes of grain yield per ha. This yield level is much better as compared to average small farms in the area. The difference is mainly due to the better use of inputs and management techniques. The education of the farmer also plays an important role due to awareness and knowledge about better agronomic practices, etc.

The other cash crop is sugarcane which is grown on 3 acres. The sugar cane yield is about 70 tonnes per ha. The farmer sells the sugarcane to sugar factory on a price of Rs 60 per $40 \mathrm{~kg}$. The summer crops are mainly maize grown on area of 6 acres. The maize grain yield is about 3.5 tonnes per ha.

The farmer also has a citrus orchard on 2.5 acres. The citrus production comes in the winter season. The fruit yields fluctuate a lot depending on the weather and plant health conditions. The productive age of citrus orchard trees is about 7 years. The orchard fields are used for intercropping with short duration crops mainly fodder. Due to large number of citrus orchards in the region, fodder production is widely adopted as an intercropping practice in Sargodha region. This might be one of the major reasons of concentration of milk production in Sargodha.

The winter fodder crops are mainly berseem (Trifolium alexandrianum), lucern (Alfa alfa) and oat (Avena sativa) which are grown separately on an area of 1.8 ha. The summer fodders are sorghum and millets which are grown on a total area of 3 ha.

The by-product of crops mainly the wheat straw which is a good source of roughage is used for feeding animals along with the green fodder. The other by-products of crops like maize stalks, sugarcane tops and leaves are also fed to the animals.

This dairy farm does not face the issue of fodder shortage due to sufficient area available for fodder cultivation on one hand and secondly better planning of sowing season. Better planning in allocation of resources for timely sowing and selection of those fodder types can produce higher crop yields and more fodder cuts.

\section{Dairy farming}

The farmer takes keen interest in the dairy enterprise. He keeps a large herd of 19 animals with nine milking animals, three heifers, six calves and one bull. The milking animals are six buffaloes of Nilli Ravi breed and three crossbred cows (Friesian cross with local Sahiwal). The average milk yield of buffaloes is $1861 \mathrm{~kg}$ and 2,025 $\mathrm{kg}$ for cow per lactation. 
The farmer adopts the better animal husbandry and management practices. The dry period of the buffaloes has improved a lot during the last four years on the farm. It has reduced to 90 days. This is achieved through timely heat detection and impregnation of animals and also through improving the nutrition and health conditions of the animals.

The farm has a male buffalo (bull) which is 24 hours available for natural mating. The breeding bull is selected from a better progeny. For maintaining good animal health, the farmer adopts vaccination program and feeds animals with required minerals and salts. The calves are de-wormed at the initial stage in first three months which helps to reduce the calf mortality rate significantly.

Figure 9: $\quad$ Medium size dairy farm in chak no 105 SB Sargodha

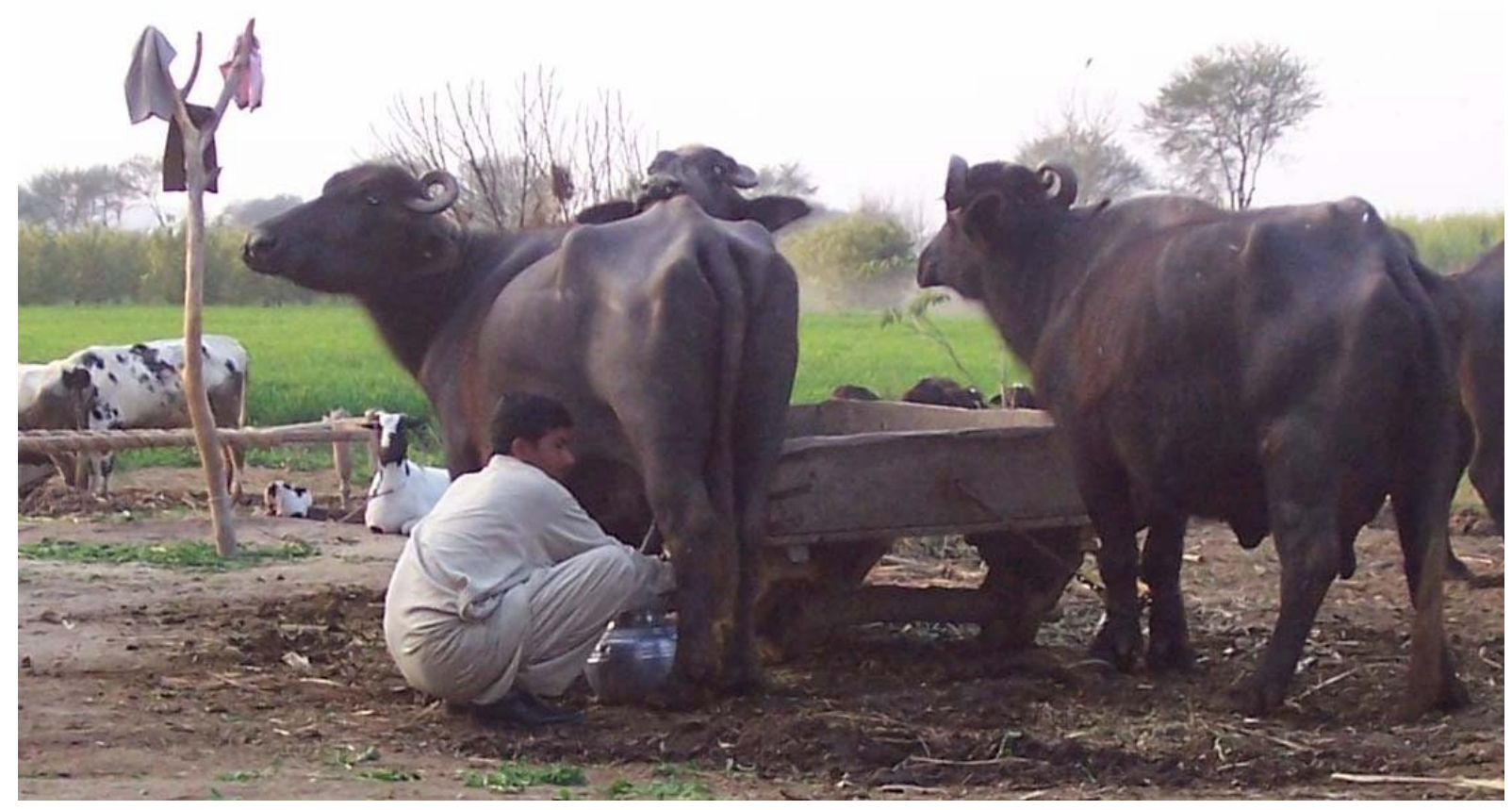

The milking animals are hand milked twice a day by the farmer with the help of labourers. The animals are fed with concentrate supplement, which is mainly cotton seed cake. ${ }^{26}$ The lactating animals get the supplement feed of about 0.9 ton per lactation.

The daily milk sale is about $16 \mathrm{~kg}$ per day in the morning to the village milkman. The evening milk is mostly consumed at home and given out as charity (4 kg milk to a religious school). The sale of milk is quite high which is about 48 percent of the total daily production. The milkman pays a milk price of Rs 12 and Rs 16 per kg for cow and buffalo milk

26

Cotton (Gossipium ssp.) seed cake of $1 \mathrm{~kg}$ contains , 930 grams of dry matter (DM), it has 271 grams of crude protein (CP), 10.3 (MJ/kg DM), metabolical energy (ME). 
respectively. The family processes the liquid milk to make some indigenous dairy products like butter, butter oil (desi ghee) and butter milk (lassi) on daily basis.

\section{Animal housing}

The farmstead is located in the green fields next to the agricultural land. The farm is located about $1 \mathrm{~km}$ off the road. The building structure is well maintained, it is made of bricks and concrete (figure 10). The floor is made of bricks. The roof tops are covered by steel structure and bricks. Separate fences are made for small calves. The small animals especially the calves move freely within the boundary wall of the shed. The sheds are airy and suitable to protect the animals from harsh weather conditions both in summer and winter season. The cow dung is removed manually from the paddock once a day.

The animals stay inside the shed and move freely in the paddock. They are fed with chopped fodder in the wooden /concrete mangers. The investment made on the farm building is about Rs 400,000 which is sufficient for keeping another 5 milking animals.

Figure 10: Animal housing at a medium size farm in chak 105 SB, Sargodha

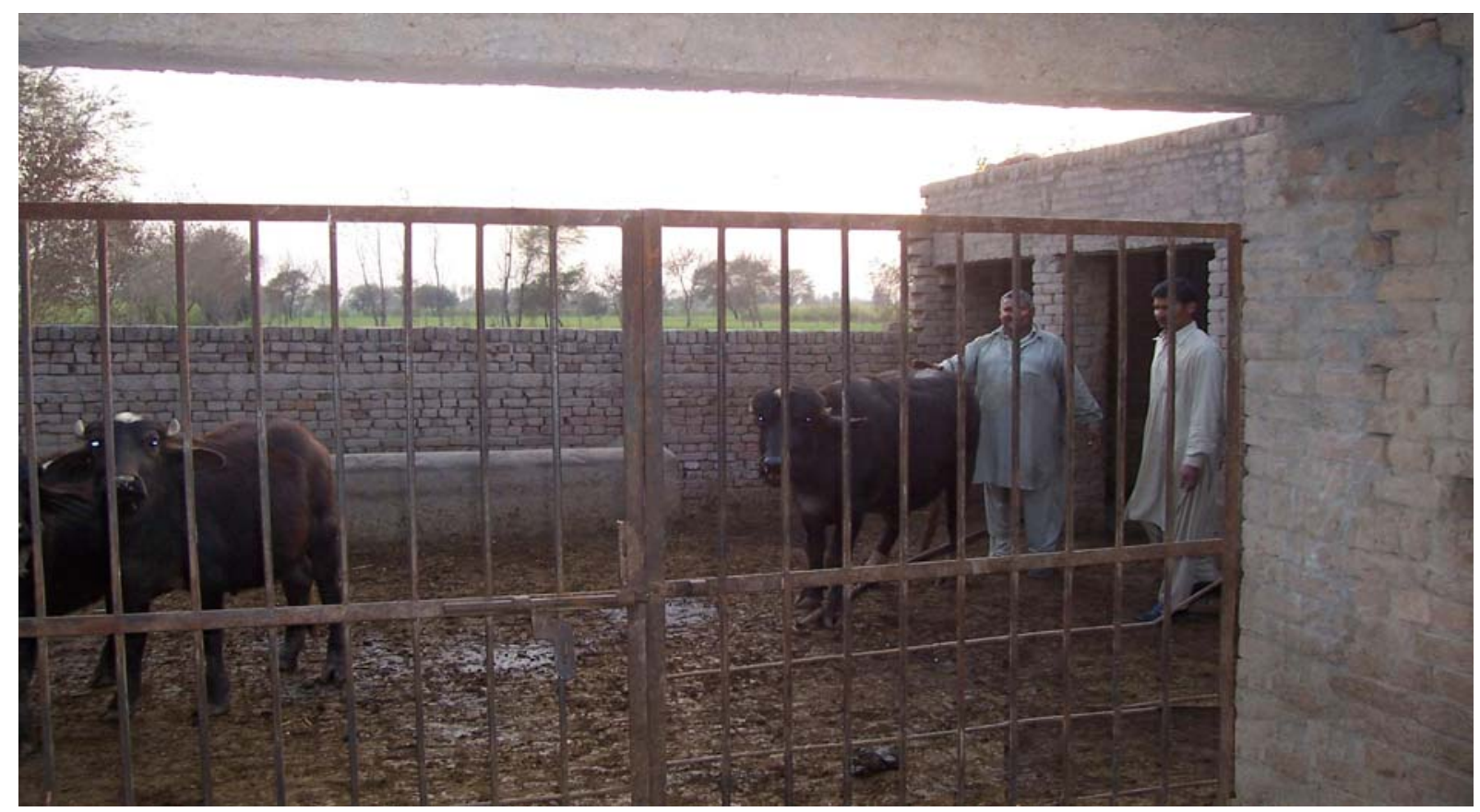

\section{Farm machinery}

The farmer has made a good capital investment in the form of farm machinery which is mainly used in the crop enterprise. The farm machinery items include the farm tractor along with the necessary agriculture implements, the fodder chopper along with engine and six wooden mangers and a donkey cart. It is mainly used on the farm to transport the fodder from the fields to farmstead. The agricultural implements mainly used in the crop 
and forage production are the soil preparation equipments i.e. cultivator, ridger and leveller. The farmer does not use the tractors full time on farm but is used in off-farm enterprise for the loading business.

\section{Management and labour}

The farm is mainly dependent on the hired labour. The family labour is not sufficient and provides only 30 percent of the labour requirements of the farm. As the rule of thumb one person can handle eight milking animals. But in this case the labour engaged both in dairy and crop farm operations. The farm labour requirement is 2 full time workers.

The farm hires an adult man and 12 years old son, both work on the farm. This hired worker lives with his family on the farmstead in the servant quarter. The hired worker also consumes the milk produced from the farm for home consumption.

\section{Dairy income}

Dairy assists the crop enterprise to generate enough cash flow besides meeting the major family food requirements. Besides the milk sales, the sale of male calves and cull cows contribute about 20 percent to the total income from the dairy enterprise. The income from milk sales is very much dependent on the calving time of the female animals. If the animal calves in summer when milk prices are higher, the milk income is higher by 20 percent. The over all share of dairy income in the farm income is about 40 percent and in the household's income is about 20 percent. The total annual dairy income is about Rs 250,000.

\section{Discussion}

Dairying is an important element of medium scale farms under mixed farming system in Sargodha region. The milk is produced mainly for home consumption as liquid milk to prepare dairy products like butter oil. On average the farmer allocates up to 15 percent of the area for fodder production. The fodder cultivation among the citrus fields is quite a common practice. The by-products from the major crops are good source of roughages (JOST 1980).

The farmer faces issues of labour shortage. It is learned after the survey and discussion with the farmer that the rural areas suffer from lack of productive labour force to work on the farm due to migration of workers from the villages to the large towns in search of better jobs. Agriculture is not considered as a well paid profession as compared to other urban jobs (TEUFEL, 2006).

The farm does not perform to its full potential. To make dairy a profitable enterprise, it has to produce more milk per year with lower cost of production. It can be mainly driven through better farm management techniques, improving labour productivity. Similarly they 
need to focus on improving milk marketing either through direct marketing in the town or sell milk to a milk company with an assured milk price.

\subsubsection{Survey results of group II, medium size farm}

The survey results are presented in a sequence to explain the variability observed within the group II, medium size farm types. The presentation of numerical results is helpful to understand the situation of the farm household's production and consumption pattern to elaborate the milk production system being followed in the region. Some of the key results outputs are presented in the form of mean, standard deviation, minimum and maximum values observed in the sample population.

The surveyed farm households showed a mean of 11 persons living per household on medium size farm type with a standard deviation of 6.9. In standard adult man equivalent unit, the average family size is 8.4 which are quite similar to the family size observed in small scale farm types (table 20).

The education level observed in medium size farm types is on average 8 years of schooling. There are farmers who have not attended the school. The average experience of the farm managers is 17 years with a standard deviation of 11.9 years (table 21).

Table 20: $\quad$ Family demographics

\begin{tabular}{lcccrr}
\hline & Mean & $\begin{array}{c}\text { Standard } \\
\text { Deviation }\end{array}$ & Min & Max \\
\hline Family size & nos & 11.00 & 6.90 & 2 & 28 \\
Male & nos & 2.33 & 1.63 & 1 & 6 \\
Female & nos & 3.78 & 2.20 & 1 & 8 \\
\hline Children & nos & 4.89 & 4.89 & 0 & 17 \\
\hline
\end{tabular}

Source: Results of farm household's survey.

Table 21: Farm manager's profile

\begin{tabular}{lcccrr}
\hline & & Mean & $\begin{array}{c}\text { Standard } \\
\text { Deviation }\end{array}$ & Min & Max \\
\hline Farm manager's age & years & 46.89 & 12.59 & 25 & 68 \\
Experience & years & 16.67 & 11.97 & 4 & 38 \\
\hline School attended & years & 8.78 & 3.99 & 0 & 14 \\
\hline
\end{tabular}

Source: Results of farm household's survey. 
The income patterns of the farm households show that crops are the main contributors to the households' income. On average the income from crop enterprise is about 50 percent of the total farm household's income. It is due to large area under cash crops which leads to better crop yields. The off-farm income is also seen quite significant in few farms. The major difference is caused by the types of off-farm activities. The share of dairy in the over all households' income is on average 20 percent which varies from farm to farm depending on the milking herd size. The farm households income ranges from Rs 150,000 to Rs 750,000 with a mean value of Rs 300,000(table 22).

Table 22: $\quad$ Farm household's income situation

\begin{tabular}{llrrrr}
\hline & & Mean & $\begin{array}{c}\text { Standard } \\
\text { Deviation }\end{array}$ & Min & Max \\
\hline Farm households income & Rs/year & 305,477 & 203,181 & 150,100 & 752,000 \\
Off-farm income & Rs/year & 90,666 & 186,473 & 0 & 600,000 \\
Income from dairy & Rs/year & 60,700 & 68,801 & 17,500 & 250,000 \\
Crop Income & Rs/year & 148,777 & 34,093 & 104,000 & 221,000 \\
\hline Other farm income livestock & Rs/year & 5,333 & 12,373 & \multirow{2}{*}{0} & 40,000 \\
\hline
\end{tabular}

Source: Results of farm household's survey.

The medium size farm type shows a mean landholding of 14 acres with a standard deviation of 2.61. Similar to the small scale farms, the medium size farms has also rented land with a mean of 7 acres and standard deviation of 5.63. The share of rented land fluctuates from zero to 80 percent of total cultivated area. On average 83 percent of the total cultivated land is used for cash crops which are mainly wheat, rice and maize crops. The proportion of land allocation for cash crops varies from 75 to 90 percent. The fodder crops occupy a mean area of $17 \%$ of the total land holding for growing both winter and summer fodder crops (table 24).

After having a look at the inventory of farm machinery and equipment on the medium size type, a significant difference is observed in the machinery list. It shows that the farms have made an average capital investment of Rs 210,000 on the farm machinery that includes mainly tractor, farm implements i.e. cultivator, loading trolley and sometimes wheat threshers (for separating grain from straw after harvesting). Additionally the farm has a fodder chopper powered through a small diesel engine (table 23).

The farm building and sheds of medium size farms are made of bricks with traditional design. The roof tops are made of wooden and steel structure. These covered sheds are used mainly for housing animals in winter. Like other two earlier cases the animals remain outside the sheds in open field close to the farm stead. The constructed sheds are used partially to store animal feed and agriculture produce. The average capital investment on farm 
sheds is Rs 105,000 (table 23).The animals are fed in feeding troughs and mangers placed under tree shades during the daytime and open-air at nighttimes. The animals have ropes/steel chains around their necks tied with the pegs dug into the ground. It is mainly done to limit the movement of animal only in feeding mangers.

Table 23: $\quad$ Landholding and farm capital

\begin{tabular}{|c|c|c|c|c|c|}
\hline & & Mean & $\begin{array}{l}\text { Standard } \\
\text { Deviation }\end{array}$ & Min & Max \\
\hline Total land & acres & 13.77 & 3.61 & 10.00 & 19.00 \\
\hline Owned land & acres & 7.04 & 4.27 & 0.0 & 39550.00 \\
\hline Rented land & acres & 6.72 & 4.61 & 0.0 & 16.0 \\
\hline Area for cash crops & acres & 11.44 & 2.62 & 8.0 & 17.0 \\
\hline Area for fodder crops & acres & 2.32 & 0.58 & 1.20 & 3.0 \\
\hline Share of area under cash crops & $\%$ & $83 \%$ & $5 \%$ & $75 \%$ & $90 \%$ \\
\hline Share of area under fodder & $\%$ & $17 \%$ & $5 \%$ & $10 \%$ & $25 \%$ \\
\hline Value of farm equipment & Rs & 209,556 & 265,440 & 8,000 & 600,000 \\
\hline Value of farm building & Rs & 104,942 & 25,136 & 65,000 & 150,000 \\
\hline
\end{tabular}

Source: Results of farm household's survey.

The family labour fulfils partially the requirements of farm labour to perform crop and dairy activities at a time. The crop operations that require manual labour are mainly crop sowing, fertilizer application, irrigation, ploughing, spraying and harvesting, etc. The dairy operations requiring manual labour to cut forage for the animals, transport from the fields to farmstead, chop, feed to the animals 2-3 times a day, bring animals to water point, milking animals twice a day, etc. The medium size farms face labour shortage due to fewer family members available to work on the farm. The women do not work in the farm and children go to schools. The grown ups work in the towns for better opportunities. The medium size farms are generally dependent on the hired labour to carry out the farm operations. The mean family labour hours are 4036 hours per year and hired labour hours are 5466 hours. (table 24). They face labour shortage especially at the time of harvesting.

Table 24: $\quad$ Labour requirement

\begin{tabular}{llcrrr}
\hline & & Mean & $\begin{array}{c}\text { Standard } \\
\text { Deviation }\end{array}$ & Min & Max \\
\hline Family labour & hours/year & 4,036 & 983 & 2,440 & 4,880 \\
Hired labour & hours/year & 5,466 & 1,808 & 0 & 5,280 \\
\hline Family labour share & $\%$ & $43 \%$ & & $41 \%$ & $100 \%$ \\
\hline
\end{tabular}

Source: Results of farm household's survey. 
The herd size of the medium farm type has a mean of 11 animals with a standard deviation of 3.6 animals. These farm types keep different types of dairy animals with a mean of 55 percent buffaloes and 45 percent cows. The cow breeds are Sahiwal, which are better local breeds and quite favourable for milk production and are disease resistant. The milk yield of the farm is relatively better than the small scale farm types with a mean production of $2068 \mathrm{~kg}$ milk per animal per year both for cows and buffaloes. The average number of calves is 3.2 which range from 2 to 5 depending on the herd size. Only few farms have a bull used for natural mating. Sometimes the farmers rent out the bull service to other farmers on Rs 50 per service (table 25).

Table 25: Dairy production details

\begin{tabular}{llrrrr}
\hline & Mean & $\begin{array}{c}\text { Standard } \\
\text { Deviation }\end{array}$ & Min & Max \\
\hline Herd size & nos & 11.33 & 3.59 & 6 & 17 \\
Milking animals & nos & 5.67 & 2.16 & 3 & 9 \\
Buffaloes & nos & 3.22 & 1.69 & 0 & 6 \\
Cows & nos & 2.44 & 1.07 & $0 \%$ & 4 \\
Buffalo share & $\%$ & $55 \%$ & $23 \%$ & 1,274 & 2,433 \\
Milk yield per animal & kg/year & 2,068 & 369 & 1 & 5 \\
Calves & nos & 3.22 & 0.92 & 0.94 & 4 \\
Heifers & nos & 2.33 & 0.31 & & 1 \\
\hline Bulls & nos & 0.11 & & & \\
\hline
\end{tabular}

Source: Results of farm household's survey.

Most of the milk produced on the farm is consumed at the home to meet the family nutritional needs. The mean sale of milk is 22 percent with highest as $16 \mathrm{~kg}$ per day. There are farms that do not sell milk at all. There are farms that sell 50 percent of their total milk production. Buffalo milk fetches 30 percent higher price as compared to cow milk mainly due to higher fat contents (table 26).

Table 26: Milk sales and home consumption

\begin{tabular}{llccrrr}
\hline & Mean & $\begin{array}{c}\text { Standard } \\
\text { Deviation }\end{array}$ & Min & Max \\
\hline Milk produced & $\mathrm{kg} /$ day & 21.44 & 6.69 & 13 & 33 \\
Milk sales volume & $\mathrm{kg}$ & 5.63 & 5.02 & 0 & 16 \\
Home consumption & $\mathrm{kg} /$ day & 17.82 & 3.26 & 13 & 23 \\
Share of milk sales & $\%$ & $22 \%$ & $18 \%$ & $0 \%$ & 20 \\
Price of Buffalo milk & $\mathrm{Rs} / \mathrm{kg}$ & 18.78 & 1.75 & 16 & 12 \\
\hline Price of cow milk & $\mathrm{Rs} / \mathrm{kg}$ & 12.63 & 0.99 & & 15 \\
\hline
\end{tabular}

Source: Results of farm household's survey. 


\subsubsection{Typical farm-PU-6}

The typical farm under medium scale farm type is formed after looking at the survey results and the expert opinion of the farm panelists. PU-6 is identified as the typical farm under this category. The cultivated land of the farm is 16 acres which includes 8 acres self owned and 8 acres rented from the neighbouring farmers. The farms are more specialized in crop farming. Dairy is considered as a secondary activity of the crop farming. The typical farm has 6 milking animals comprising of four buffaloes and two local cows. The farm grows its own green fodder. The animals are fed with green fodder and the by products of the main crops like wheat, rice straw and sugarcane tops. The animals are fed with supplement feeding with concentrates. The concentrate feed consists of cotton seed cake which is mostly used as supplement feed. Only the lactating animals are fed with concentrate feed. The milk yield is 1800 and $2160 \mathrm{~kg}^{27}$ per lactation for buffaloes and cows respectively. The home consumption of dairy is about 49 percent. The share of dairy income in the overall household income is 17 percent. The economic parameters of milk production and net household income of PU-6 typical farm are described later in section 4.4.2 of this chapter.

\subsection{Group III, Large Scale Farm}

The Group III, large scale farm types have landholdings of more than 20 acres. The land holdings include both the owned and rented land. The situation of milk production and the farm households is explained through three steps with the sequence of case study, statistical analysis (showing mean, standard deviation, minimum and maximum of key variables). Finally the selection of a typical farm showing the key production and economic outputs of farm households and milk production.

\subsubsection{A case study of large scale farm}

The case study method is chosen to describe the situation of large scale farm type under mixed farming system found in Punjab. The socio-economic situation of the farm households is briefly described. It describes the farm household's resources by answering questions pertaining to demographics of a farm household, allocation of resources among various enterprises, income generation patterns, etc. It elaborates the income pattern of the farm households from different farm and off-farm enterprises. It further explains the allocation of land, labour and capital resources among various farm activities.

27

Milk with natural fat and protein contents without adjustment to ECM. 
For getting all these details, one farm household that comes under large scale category is chosen from the region Sargodha. Mr. Irshad ullah owns a large type farm in chak no. 105 SB which is selected as case study to understand the milk production.

The interview of the farmer was conducted in the afternoon on the farm. All the farm planning and management strategies were discussed in details.

\section{General farm details}

The farm owns 55 acres (22 ha.) of arable canal irrigated land. The farmstead is located in the green fields adjacent to the metal road connecting the village with the main highway. The family of the farmer lives in the nearest town of Sargodha which is about $15 \mathrm{~km}$ from the farm. Crop farming is the main thrust of the farm and dairy as a supplement activity. The farm keeps a large herd of 29 animals with 48 percent milking animals (14 milking animals) and rest are calves and heifers, etc.

\section{Household's profile}

The farmer is 65 years old and has more than 40 years of farming experience. He is married and has eight children. He lives with his wife. His children are also married and live in separate household. The farmer has got secondary school certificate from the nearest town of Sargodha (10 years of schooling). He adopted farming as a full-time business in 1968. The socio-economic situation of the farmer is considerably stable. He owns a house in the city and uses a car for transport purpose.

\section{Off- farm income}

The farmer has no direct source of off-farm income which is linked with the farm households. His children are well-educated and employed in the towns. They live separately so their income cannot be counted in off-farm income of the farm households.

\section{Crop farming}

Since crop farming is the major focus of the large farm types, he grows cash crops on 90 percent of his landholding. The major winter crops are wheat and sugar cane. The main summer crops are maize and rice. The decision of allocation of area under crop cultivation is mainly based on the prices of the agricultural commodities in the market which fluctuates depending on principle of supply and demand. If the price of one crop is better then the other then farmer plans to grow that crop with more area next year.

The average yield of wheat grain is 4 tonnes per ha. In case of sugar cane, the average yield is 80 tonnes per ha. Similarly the average yield of maize achieved on this farm is about 3 tonnes per ha. This yield level is much better as compared to two other described cases. The main reason behind this difference is the higher use of inputs due to better buy- 
ing power of the farmer. Further he uses better ratios of seed, fertilizer and other inputs on the farm.

The crop harvesting is done manually by the permanent hired labour or through the seasonal labour force. The grains are separated out of the trash through mechanical thresher. In case of sugarcane, it is harvested manually, after removing the tops and leaves, the canes are transported to the nearest purchase centre of a sugar mill. The sugar cane tops are fed to the animals.

In general, the area under fodder crops comprises of 10 percent of the total arable land. The fodder crops are mainly grown two to three times a year during the winter and summer seasons. The winter fodder crops grown on the farm are berseem and lucern along with oat that are grown on a total area of 6 hectares. The winter fodder are mostly multi cut and give three to four cuts depending on the crop and use of inputs specially irrigation and fertilizer. The summer crops are mainly maize forage, sorghum and millets.

\section{Dairy farming}

The farm has 14 milking animals with nine buffaloes of selected breed Nilli Ravi and five crossbred cows. Dairy is the supplement activity of the farm and most of the feed items are attained from the major crops i.e. wheat straw, rice straw and maize stalks, etc. The average milk yield per animal is $2500 \mathrm{~kg}$ per lactation. The daily milk production of the whole herd is $96 \mathrm{~kg}$. The milk yield is better than the small and medium farm types. It is mainly due to better feeding, breeding and management practices adopted on the farm.

The animal breeding is done through natural mating most of the times in case of buffaloes. The farm keeps a male buffalo (bull) which is meant for mating buffaloes whenever it is necessary. Since the buffaloes are silent heaters, it is difficult to detect the service requirement by the farmer. Keeping a bull can be necessary to detect the heat on accurate time and offer service at appropriate time.

The crossbred cows are inseminated through artificial insemination (AI). The farmer has made arrangements with an AI technician who visits the farm for insemination whenever a need arises. The AI costs are higher which include the semen cost, labour and transport costs. The AI cost per animal varies from Rs 250 to Rs 400 depending on quality of the semen and the number of times an animal is inseminated

The family labour is not available all the times to work on the farm as all of the children are educated and employed in the closer city of Sargodha. The owner is the only family person to look after the agricultural activities. The rest of all farm operations are carried out through hired work force. 
The farm has 3 hired full-time workers; two of them work full-time within the dairy enterprise while one worker works as a tractor operator. He also does the other crop farming related work on the farm. The occasional labour is hired to perform specific crop farming operations which are mainly at the time of harvesting and threshing.

The efficiency of the workers is very much dependent on the supervision. The large farms face the issue to find a skilled and reliable worker to work on the farm. To assure the availability of workers round the year, the farmer pays the salaries in advance.

The workers live on the farm to look after the animals' full time (during the day and nighttimes). To retain skilled workers on the farm is a major issue faced by the large farmers. The farm workers get better options to work in the city and earn more money as compared to work on a farm. The farm wage of a skilled worker is Rs 24000 per year. The wages on the farm are generally lower i.e. almost half of the wage that a worker can earn by working in the city or in the industry. This situation causes a competition between the rural and urban employment. The situation of skilled labour is even worst in areas closer to the major towns that have more employment opportunities.

The milking animals are milked manually two times a day. The milk is sold to a milkman who buys milk at Rs 17 and Rs 13 per kg for the buffaloes and cows milk respectively. The milk sale is 45 percent of the total production. The rest of 55 percent milk is used for home consumption by the household and the workers working on the farm. The liquid milk is consumed at home and used to process into different local products which are butter oil (desi ghee), butter and butter milk (lassi), etc.

Figure 11: Large scale farm type in 105 SB, Sargodha

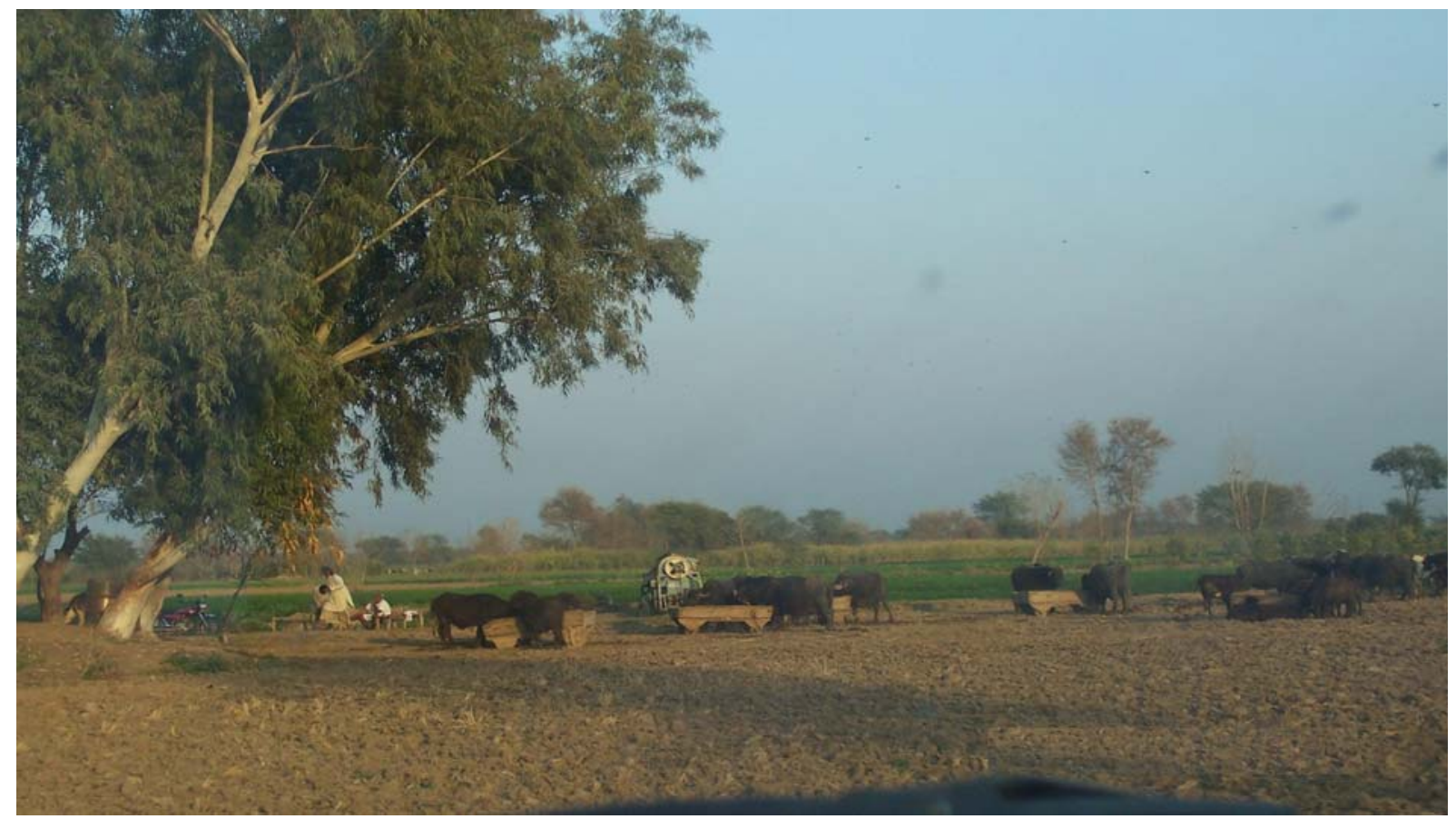


The milking animals are fed with the high energy concentrates, which are mainly cotton seed cake and mixed ration. Each animal is fed about $2 \mathrm{~kg}$ of concentrate, 2 times a day. The quantity of concentrate used per animal depends on the animal performance. The high yielding animals are fed more as compared to low yielding animals. The lactating animals are fed with average 1.2 tonnes of concentrate per lactation.

The dry animals are mostly fed with green fodder and wheat straw. The calves suckling is practiced for an initial period of 3 months. Later on, the milk is provided partially with green fodder to the calves. From 6 months age onwards, the calves are purely fed with green fodder and wheat straw.

\section{Animal housing}

The animal housing conditions are relatively better and are able to protect the animals during harsh weather times. The building consists of sheds for the animals and feed storage area. Current value of the building is Rs 350,000. The animals stay generally in the nearby fields outside during the daytime in winter. The animals stay mostly outside in summer. Animals are kept under the shade of trees in the summer during daytime. Keeping animals outside the farm sheds in the field helps to deliver the dung into the fields directly. The animals are rotated in the fields for uniform spread of manure.

\section{Farm machinery}

The farm is well equipped to perform tillage and partially harvesting operations. The farmer has made a capital investment of Rs 500,000 on the farm machinery in the form of tractor (65 horsepower), tillage equipment (mainly cultivator, chisel plough), trolley, mechanical thresher and chopper, etc.

Figure 12: Farm building structure of the large scale farm type

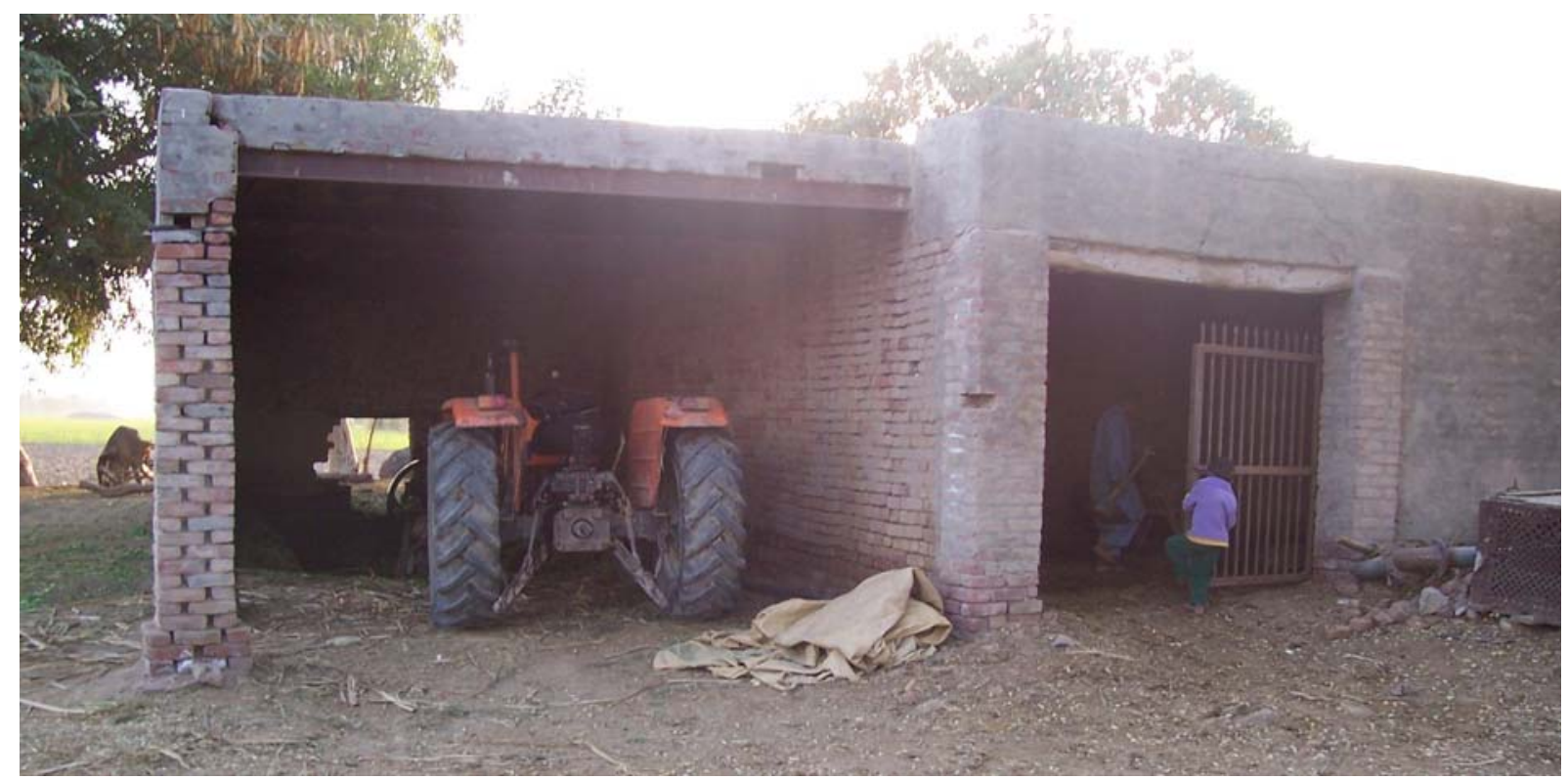




\section{Discussion}

The large farm types in rural area are not commercial oriented in dairy production in the study area but their main preference is crop farming. They keep a large herd of animals mainly as a source of milk production for home consumption and prestige. Generally the large farm households consume a large share of their milk output as a home consumption. The total milk consumed in a household is mainly used as liquid milk and for preparation of dairy products which are butter oil (desi ghee) and butter milk (lassi), etc. The dependence of dairying households on purchased vegetable oil is reduced as compared to non dairying households in the villages. An additional advantage of processing liquid milk into butter oil (ghee) will help to increase the shelf life of dairy products and produce a byproduct drink i.e. butter milk (lassi) (JOST, 1980).

The large scale farmer sells limited quantities of milk. He generates enough income from sale of livestock animals. The revenue generated from milk sales is mainly utilized for purchase of feed grains and concentrates, etc. Milk is sold to the milkman on credit basis who collects milk in the morning. The milk payments are received within one to four weeks time depending on the supply of milk.

Like the other two cases, the large farm type also shows seasonality in milk production due to higher number of buffaloes which do not calve during hot months in summer. The buffalo calving occurs in the months of September/October. The seasonality in milk causes shortage of milk in hot months in summer. As a result, the milk prices are increased during milk shortage period in summer and reduced during the flush season in winter and spring.

The productivity of the dairy farm is low as compared to their potential under current circumstances. This can be improved through improving breeding, animal husbandry and management practices on the farm. In general, the farm households under this category are financially stable and can afford to make additional investment leading to improvement in productivity. If these farms are developed for the dairy production, they can be helpful to produce bulk amount of milk to fulfil the domestic demands of milk in Pakistan.

\subsubsection{Survey results of group III, large scale farm type}

The survey results are presented in a sequence to explain the variability observed within the group III, Large scale farm type. The presentation of statistics are made here to understand the situation of farm households and milk production system followed under the mixed cropping system found in irrigated region in Punjab province. 
Some of the key facts are presented in the form of mean, standard deviation, minimum and maximum values observed in the sample population. The surveyed farm households showed a mean of 14 persons living per family with a standard deviation of 5.7. In standard adult man equivalent unit, the average family size is 10.8 which are higher than the two other farm types mentioned above (table 27).

The educational level is observed to be better in large scale farm. It is mainly due to better economic conditions of the family. There are farmers with graduate degrees (14 years of school) but their proportion is very small. Most of the farmers on average have passed intermediate school certificates (12 years of school). Nearly all the farmers in this area have attended school which helps them to have a better knowledge about farming through adopting improved practices. Besides education they have also a good experience which has a mean of about 30 years (table 28).

Table 27: $\quad$ Family demographics

\begin{tabular}{lccccc}
\hline & Mean & $\begin{array}{c}\text { Standard } \\
\text { Deviation }\end{array}$ & Min & Max \\
\hline Family size & nos & 14.17 & 5.79 & 7 & 24 \\
Male & nos & 4.00 & 1.91 & 1 & 6 \\
Female & nos & 3.33 & 1.49 & 2 & 6 \\
\hline Children & nos & 6.83 & 3.08 & 4 & 12 \\
\hline
\end{tabular}

Source: Results of farm household's survey.

Table 28: $\quad$ Farm manager's profile

\begin{tabular}{llccrr}
\hline & Mean & $\begin{array}{c}\text { Standard } \\
\text { Deviation }\end{array}$ & Min & Max \\
\hline Family size & nos & 14.17 & 5.79 & 7 & 24 \\
Farm managers age & years & 56.00 & 14.91 & 29 & 72 \\
Experience & years & 29.50 & 18.37 & 1 & 55 \\
\hline School attended & years & 11.00 & 2.24 & 8 & 14 \\
\hline
\end{tabular}

Source: Results of farm household's survey.

The farm household's income is mainly driven by the crops income followed by off-farm income. The off-farm income comes mainly from off-farm job i.e. working in a government or private departments or having an off-farm enterprise outside the farm. The other farm income share is insignificant and is not included in the comparison. The farm household's income mostly comes from the crop farming activity. The dairy income comes from milk sales and livestock sales of calves and cull animals. 
Table 29: $\quad$ Farm household's income situation

\begin{tabular}{llrrrr}
\hline & & Mean & $\begin{array}{c}\text { Standard } \\
\text { Deviation }\end{array}$ & Min & Max \\
\hline Farm household income & Rs/year & 695,791 & 208,677 & 426,000 & $1,070,000$ \\
Off-farm income & Rs/year & 126,666 & 122,565 & 0 & 36,000 \\
Income from dairy & Rs/year & 118,708 & 79,325 & 35,000 & 250,000 \\
\hline Crop Income & Rs/year & 450,416 & 24,726 & 221,000 & 915,000 \\
\hline
\end{tabular}

Source: Results of farm household's survey.

The large scale farms have a mean land holding of 38 acres with a standard deviation of 16.6 acres from the selected sample. They are generally more dependent on crop farming. They use an average 87 percent of the land to grow cash crops. The large farms allocate only small proportion of their total land to grow fodder crops (mean of 13 percent land allocated for fodder production). The most common crops grown in winter season are wheat and sugar cane. While in summer the major crops are maize and rice. The citrus orchards are also an important feature of large scale farms (table 30).

The large scale farms have made relatively larger capital investment in the farm machinery and equipment. The capital investment in farm machinery is in the form of a tractor, wheat thresher, trolley and other tillage equipments. Similarly they have also made reasonable farm building structure that can be used round the year.

Table 30: $\quad$ Landholding and farm capital

\begin{tabular}{|c|c|c|c|c|c|}
\hline & & Mean & $\begin{array}{l}\text { Standard } \\
\text { Deviation }\end{array}$ & Min & $\operatorname{Max}$ \\
\hline Total land & acres & 37.42 & 16.61 & 20 & 65 \\
\hline Owned land & acres & 33.08 & 16.19 & 17 & 61 \\
\hline Rented land & acres & 4.33 & 1.11 & 3 & 6 \\
\hline Area of cash crops & acres & $87 \%$ & $4 \%$ & $80 \%$ & $94 \%$ \\
\hline Area of fodder crops & acres & $13 \%$ & $4 \%$ & $6 \%$ & $20 \%$ \\
\hline Share of area under cash crops & $\%$ & 35.00 & 18.03 & 20 & 65 \\
\hline Share of area under fodder crops & $\%$ & 3.63 & 9.94 & 0 & 12 \\
\hline Value of farm equipment & Rs & 601,500 & 84,919 & 500,000 & 700,000 \\
\hline Value of farm building & Rs & 150,833 & 69,487 & 75,000 & 250,000 \\
\hline
\end{tabular}

Source: Results of farm household's survey.

In spite of large family size, the family members engaged in farm operations are fewer as compared to small and medium farm types. The owners of these farm types have better income resources and send their children to cities to avail better opportunities of education. After getting better education, they prefer to work in the cities for better income rather than coming back to village to work on the farm. 
On average up to 43 percent of the labour requirements are fulfilled from the family labour. More than 57 percent of the labour requirements are fulfilled by hiring full-time workers on the farm (table 31). The dependence on hired labour is relatively higher in large farm type. The availability of skilled and motivated labour force is the serious concern of the large farm types because of large migration of workforce from the rural areas to urban centres.

Table 31: Labour requirement

\begin{tabular}{llcccc}
\hline & & Mean & $\begin{array}{c}\text { Standard } \\
\text { Deviation }\end{array}$ & Min & Max \\
\hline Family labour & hours/year & 2,816 & 1,567 & 1,220 & 6,100 \\
Hired labour & hours/year & 3,881 & 2,631 & 2,640 & 9,760 \\
\hline Family labour share & $\%$ & $43 \%$ & $16 \%$ & $19 \%$ & $70 \%$ \\
\hline
\end{tabular}

Source: Results of the farm household's survey.

The average herd size of large farm types is 18 heads. More than 72 percent of the milking animals are buffaloes. The proportion of cows in some herds is 30 percent (table 32). The large scale farms pay more attention to the crop farming activity. These farms keep dairy animals as a secondary activity mainly to produce milk for home consumption and also for prestige reasons. Dairy is not considered as a full-time commercial activity. The sale of livestock animals in the form of calves and cull cows provides an extra income to the farm household from the dairy activity.

Table 32: $\quad$ Dairy production and milk marketing details

\begin{tabular}{llrrrr}
\hline & Mean & $\begin{array}{c}\text { Standard } \\
\text { Deviation }\end{array}$ & Min & Max \\
\hline Herd size & nos & 18.50 & 8.77 & 8 & 31 \\
Milking animals & nos & 9.83 & 4.37 & 5 & 17 \\
Buffaloes & nos & 6.67 & 1.89 & 4 & 9 \\
Cows & nos & 3.83 & 2.48 & 1 & 8 \\
Buffalo share & $\%$ & $73 \%$ & & $53 \%$ & $100 \%$ \\
Milk yield per animal & kg/year & $2,671.3$ & 181.4 & 2,398 & 3,005 \\
Calves & nos & 5.17 & 1.95 & 2 & 8 \\
Heifers & nos & 4.00 & 2.10 & 0.00 & 7 \\
\hline Bulls & nos & 0.33 & 0.47 & & 1.00 \\
\hline
\end{tabular}

Source: Results of farm household's survey.

A wide variation is observed in annual milk yield per animal among the large farm types. The major difference is mainly due to the breed and the management practices being adopted. In comparison to small and medium farm types, the milk yield is better but still needs an improvement. 
Most of the milk (70 percent) is consumed at home to prepare dairy products for internal use. The home consumption of milk is substantially higher. Dairy farming is not considered as a commercial activity on large farms but rather a sign of social prestige. The percentage of milk sale shows an average of 25 percent milk sales per day (table 33).

Table 33: $\quad$ Milk sales and home consumption

\begin{tabular}{|c|c|c|c|c|c|}
\hline & & Mean & $\begin{array}{l}\text { Standard } \\
\text { Deviation }\end{array}$ & Min & Max \\
\hline Milk produced & $\mathrm{kg} /$ day & 51.33 & 25.98 & 25 & 98 \\
\hline Milk sales volume & $\mathrm{kg}$ & 15.83 & 14.26 & 0 & 40 \\
\hline Home consumption & $\mathrm{kg} /$ day & 35.50 & 11.71 & 25 & 58 \\
\hline Share of milk sales & $\%$ & $25 \%$ & $15 \%$ & $0 \%$ & $41 \%$ \\
\hline Price of Buffalo milk & $\mathrm{Rs} / \mathrm{kg}$ & 19.00 & 1.41 & 17 & 20 \\
\hline Price of cow milk & $\mathrm{Rs} / \mathrm{kg}$ & 12.50 & 0.50 & 12 & 13 \\
\hline
\end{tabular}

Source: Results of the farm household's survey.

\subsubsection{Typical farm-PU-9}

The typical farm under large scale farm type is formed after looking at the survey results and the expert opinion of the farm panelists. PU-9 is identified as the typical farm in this category. Under this category, the cultivated land of the farm is 25.5 acres which is all self owned. The farm is more specialized in crop farm and has citrus orchards also. Dairy is considered as a secondary activity after the crop farming. The typical farm has 9 milking animals comprising of six buffaloes and three crossbred cows. The farm grows its own green fodder. The animals are fed with green fodder and the by products of the cash crops which are wheat, rice straw and sugarcane tops. The concentrate feeding consists of cotton seed cake and ration. The animals are hand milked twice a day. The farm has made significant capital investment in machinery and building. Dairy is not a fully commercial activity. Most of the milk produced is used for home consumption. The milk yield is 2160 and $2340 \mathrm{~kg}^{28}$ per lactation for buffaloes and cows respectively. The share of dairy income in the overall household income is 16 percent (details are mentioned in comparison of typical farm in section 4.4 .2 of this chapter). 


\subsection{Comparison}

The comparison is made for the selected variables among the farm types and the typical farms found in the study region in this section. This cross comparison is helpful to describe the reasons behind the differences and similarities found in cross-sectional survey under mixed cropping system in Sargodha region in Punjab.

\subsubsection{Cross comparison of farm household survey results}

The results of the farm household survey are compared for the key variables observed in all three farm types. The mean values are compared to show similarities and differences among the farm types in household and milk production parameters.

The key differentiating factor found on the basis of demographics is that the large farm types have large family size of 14 members. ${ }^{29}$ The age of the farm manager is higher in large farm types as compared to small and medium farm types. Interestingly it is found that the experience of the farmers is observed highest as 31 years in small scale farms and lowest of 17 years in medium type farms. The reason behind this difference is that in case of small scale farm, the farmer's son is engaged in farming from an early age as compared to medium and large size farms due to lack of schooling. To verify this argument, it is found that the managers/owners of small-scale farms get lesser chance of education due to poor economic conditions as compared to large farms which have better economic conditions. The average number of years of school attended is almost double in medium size farms as compared to small scale farms.

The highest education rate is found in large farm types that showed that the farmers have attended 12 years of schooling on average. The level of education is an important factor to transform knowledge about new technologies and is found that they are relatively more motivated to adopt new technologies as compared to less educated farmers (table 34).

Table 34: $\quad$ Farm household's demographics

\begin{tabular}{llccc}
\hline & & Sm all scale & Medium scale & Large scale \\
\hline Family size & nos & 10.57 & 11.00 & 14.17 \\
Farm manager's age & years & 49.76 & 46.89 & 56.00 \\
Experience & years & 31.43 & 16.67 & 29.50 \\
\hline School attended & years & 4 & 9 & 11 \\
\hline
\end{tabular}

Source: Results of the farm household's survey.

29 It may be contradicting in the real situation; usually the small farms have large family size as more workforce is considered as sign of prosperity (KUROSKI, 1998). 
The farm household's income is seen to increase with the increase of farm size. The increase in farm income shows a correlation with the farm size. The off-farm income shows significant differences among three farm types which is mainly due to the investment availability with a farm type.

The dairy income showed significant differences among all the three farm types. The reason behind this difference is mainly due to the size of milking herd and secondly the differences in genetic potential, animal husbandry and farm management practices of farm types (ZAFAR, 1985; KUROSAKI, 1995; FISCHER, 2000).

The small farm type shows the lowest dairy income of Rs 34,000 while the medium scale farm has almost double the income. The large-scale farms have three times higher dairy income as compared to small-scale farms. The crop income shows similar increasing trend with the increase of farm size.

The other farm income is mainly seen in small and medium type farms. Since the small scale farms tend to depend more on different sources of income due to their risk aversion nature. The share of other farm income is higher in small-scale farms and decreases for the medium size farms. The other farm income mainly comes from the sale of other livestock animals which are mainly goat, sheep and poultry, etc. Most of the large-scale farm types are not involved in other farm activities (table 35).

Table 35: $\quad$ Farm household's income

\begin{tabular}{llccc}
\hline & & Small scale & Medium scale & Large scale \\
\hline Off-farm income & Rs/year & 19,800 & 90,667 & 126,667 \\
Dairy income & Rs/year & 34,228 & 60,700 & 118,708 \\
Crop income & Rs/year & 32,450 & 148,778 & 450,417 \\
Other farm income (livestock, etc.) & Rs/year & 5,571 & 5,333 & \\
\hline Households income & Rs/year & 91,106 & 305,478 & 695,792 \\
\hline
\end{tabular}

Source: Results of the farm household's survey.

The landholding is the key factor considered for the classification of farms into small, medium and large types. The small farm types have on average total cultivated land of 4 acres while medium and large farm have 14 and 38 acres respectively found under mixed cropping system in Sargodha region. The cultivated land includes both the owned and rented land.

Under mixed cropping system, the major use of land is seen under cash crops which vary from 66 to 87 percent. Proportion wise the area under fodder cultivation is seen higher in small farm types as compared to large scale farm types (table 36). 
Table 36: Land allocation

\begin{tabular}{llcrr}
\hline & & Small scale & Medium scale & Large scale \\
\hline Total cultivated land & acres & 4 & 13.77 & 37.42 \\
Area under cash crops & acres & 3 & 11.44 & 33.08 \\
Area under fodder crops & acres & 1 & 2.32 & 4.33 \\
Share of area under cash crops & $\%$ & $66 \%$ & $83 \%$ & $87 \%$ \\
\hline Share of area under fodder crops & $\%$ & $29 \%$ & $17 \%$ & $13 \%$ \\
\hline
\end{tabular}

Source: Results of the farm household's survey.

The comparison of the capital investment made in the form of farm assets as farm equipment and building (table 37). The small farm type has made a small capital investment in farm equipment and building. The farm operations are done most of the times manually or the required machinery especially the tractor for tillage operations is hired from other large farmers in the village.

The investment in farm building is mainly driven by the size of the animal herd and the economic conditions of the farmer. The medium and large scale farms have made significant capital investment in farm machinery and equipment due to the size of their operations (table 37). The animal housing trend is very simple in the region. They are constructed only to keep animals during harsh weather conditions specially to protect against cold wave during the winter months. Since winter lasts only for 3 months and rest of the year it is hot. So this building is used most of the time to store animal feed and agricultural produce. Only a few progressive farms have prepared proper sheds that can be used round the year but none of such farm was included in the survey.

The housing structure of the small farm type is very poor and lacks protection against harsh weather conditions. Due to un-hygienic conditions the small farms have showed higher mortality rate especially in calves.

Table 37: $\quad$ Farm assets

\begin{tabular}{lcccc}
\hline & & Small scale & Medium scale & Large scale \\
\hline Value of farm equipment & Rs & 23,350 & 209,556 & 601,500 \\
Value of farm building & Rs & 52,471 & 104,942 & 150,833 \\
\hline
\end{tabular}

Source: Results of the farm household's survey. 
The family labour engagement is observed to be highest in small scale farm types. All of farm labour requirements are fulfilled from family resources due to enough availability of family members in the household.

The medium and large farm types face shortage of labour availability due to more requirement of labour due to large size of operations. They tend to fulfil their labour requirement through hired labour. In most of the cases of medium and large farm types, the children go to school and after finishing education, they get employment opportunities in the urban areas. The labour availability is a big concern for large farm types under mixed cropping system (table 38).

Table 38: Family labour

\begin{tabular}{llccc}
\hline & & Small scale & Medium scale & Large scale \\
\hline Family labour & hours/year & 4,784 & 4,036 & 2,816 \\
Hired labour & hours/year & 13 & 1,466 & 3,881 \\
\hline Family labour share & $\%$ & $99 \%$ & $78 \%$ & $43 \%$ \\
\hline
\end{tabular}

Source: Results of the farm household's survey.

The average herd size and milking animals show an increasing trend from small scale to medium and large scale farm types. The average number of buffaloes is 2 in case of small farm type, 3 in case of medium size farm and 7 are in large scale farm type. Over all among all three farm types, buffalo is the main dominating animal. The proportion of cows is seen higher in medium size farm types as compared to other types. All farm types raise heifers to replace older and low yielding animals (table 39).

Table 39: $\quad$ Dairy parameters

\begin{tabular}{llcrr}
\hline & & Small scale & Medium scale & Large scale \\
\hline Herd size & nos & 7.29 & 11.33 & 18.50 \\
Milking animals & nos & 3.52 & 5.67 & 9.83 \\
Buffaloes & nos & 2.14 & 3.22 & 6.67 \\
Buffalo share & $\%$ & $63 \%$ & $55 \%$ & $73 \%$ \\
Milk yield per animal & kg/year & 1,675 & 2,068 & 2,672 \\
Cows & nos & 1.45 & 2.44 & 3.80 \\
Calves & nos & 2.15 & 2.22 & 5.17 \\
Heifers & nos & 1.62 & 0.11 & 0.33 \\
\hline Bulls & nos & 0.11 & & 0.00 \\
\hline
\end{tabular}

Source: Results of farm household's survey. 
The milk yield per animal varies significantly among all the three farm types. The small scale farm types are low yielding due to poor genetic potential of milk animals, poor feeding and management as compared to medium and large scale farm types. There is a significant difference among all the three farm types in terms of daily milk produced per day as well.

The milk sales are the key feature of all the farm types found under the mixed cropping system. All farm types sell milk and the sales volume depends on the surplus milk left from home consumption. The small scale farm types sell higher proportions of their total milk produced which is about 40 percent compared to 22 and 25 percent in medium and large farm types (BHATTI et al., 1989; ZAFAR, 1985).

The highest home consumption of milk is observed in large scale farm type. The large scale farms consume more milk as a liquid and also to make various indigenous dairy products like butter oil (desi ghee), butter and butter milk (lassi), etc. There is not a significant difference of milk prices observed among the entire three farm types as they follow more or less similar strategy for sale of milk. The milk prices showed higher milk prices for buffalo milk and lower for cow milk in all three farm types (SCHINZEL, 1979b) (table 40).

Table 40: $\quad$ Milk sales and home consumption

\begin{tabular}{llccc}
\hline & & Small scale & Medium scale & Large scale \\
\hline Milk produced & $\mathrm{kg} /$ day & 11 & 21 & 51 \\
Milk sale & $\mathrm{kg} /$ day & 4 & 6 & 16 \\
Share of milk sales & $\%$ & $39 \%$ & $22 \%$ & $25 \%$ \\
Home consumption & $\mathrm{kg} /$ day & 7 & 16 & 36 \\
Price of buffalo milk & Rs/kg & 18.6 & 18.8 & 19 \\
\hline Price for cow milk & Rs/kg & 13.5 & 12.6 & 12.5 \\
\hline
\end{tabular}

Source: Results of the farm household's survey.

\subsubsection{Typical farms comparison}

The concept of typical farm is followed in this study to understand the status quo situation of milk production under mixed cropping system in Punjab. All steps are followed necessary to set up a typical farm. The panel approach is followed to set up a typical farm and verify the results through consensus of the panel members. The panel members included the farmers living in the study region who know their day to day activities and have similar production circumstances. To ensure the quality of the data and its precision, different cross questioning procedures were adopted during interviewing the panel of farmers. 
It is assumed that farm types selected subjectively include all farm types found in the region defined by the survey results. All the three farm types identified through primary survey consist of few to many farm households.

Three typical farms are finally selected from each farm type for status quo analysis of the farm household's and milk production situation. The selected three typical farms are $\mathrm{PU}^{30}$ 3, PU-6 and PU-9 representing small scale, medium and large scale farm types dominating the milk production under mixed cropping system found in Sargodha region.

The status quo analysis of farm types is helpful to understand the situation of milk production in the region and later on used to define various farm strategies on the basis of their existing outlook. Few of the relevant and important result variables are described here at three levels of household, farm and dairy enterprise.

\section{Size of farm household}

Usually the family sizes are large in the rural areas due to increasing requirement of work force to earn income for the family. The farm managers are relatively younger in medium type typical farm (PU-6). The number of family members is similar in PU-6 and PU-9. After converting all the family members into adult man equivalent unit ${ }^{31}$, it is found that the highest adult man equivalent is available in typical farm PU-3.

This shows that the small farm PU-3 has enough labour available to work on the farm. Any strategy focusing on engaging the family labour will be beneficial to improve the income situation of small scale farms to overcome the lower productivity and provide employment opportunities. The old age parents provide an extra help in various dairy operations (table 41). 
Table 41: Adult man equivalent ${ }^{32}$

\begin{tabular}{llrrr}
\hline & & PU-3 & PU-6 & PU-9 \\
\hline Adult man equivalent & nos & 4.8 & 4.6 & 4.1 \\
Adult men $(>18)$ & nos & 2 & 1 & 2 \\
Adult women $(>18)$ & nos & 1 & 1 & 1 \\
Old age parents $(>65)$ & nos & 2 & 1 & 1 \\
Children between 14-18 & nos & 1 & 2 & 2 \\
Children under 14 & nos & 2 & 1 & 2 \\
\hline Family size & nos & 7 & 6 & 6 \\
\hline
\end{tabular}

Source: Results of the typical farm selected from farm household's survey.

The average age of farm managers in all typical farms is above 45 years. The experience in farming is more than 15 years in all typical farms. The farm manager of typical PU-3 started farming at the age of 17 years old. Usually the small farmers do not get chances of education and are engaged in farm work along with parents from early age due to economic reasons. The managers of medium and large farms have better chances to attend school. They have attended schools for 10 to 12 years respectively (table 42).

Table 42: $\quad$ Farm manager's profile

\begin{tabular}{llccr}
\hline & & PU-3 & PU-6 & PU-9 \\
\hline Family size & nos & 7 & 6 & 6 \\
Farm manager's age & years & 47 & 46 & 70 \\
Experience & years & 30 & 18 & 25 \\
\hline School attended & years & 4 & 10 & 12 \\
\hline
\end{tabular}

Source: Results of the typical farm selected from farm household's survey.

The family labour engagement of the male members is observed to be full-time in small typical farm. The medium and large typical farms have partial engagement of the family labour in the farm operations. The reason behind this difference is mainly because they send their children for better education and find better jobs to work in the urban areas.

32 To calculate the standard man equivalent of all the family members that are staying in the farm households, all of them are converted into standardized adult man equivalent by using man adult equivalent ratio. The ratio elaborates adult man $(>18)$ is equal to 1 , adult woman $(>18)=0.92$, old age parents $(>65)=0.80$, children $(14-18$ year $)=0.85$, children (under 14 year) $=0.25$ (BRADSHAW and MILLAR, 1991). 
The trend has changed nowadays, the government is keen to increase the literacy rate in villages and for promotion of education at primary level, the government of Punjab offers free books and other incentives for children to be sent in schools. If the government policy showed continuity then the literacy rate can be raised to double in the coming years.

After looking at the family living expense structure, it is found that 60 to $70 \%$ of the farm household's budget is allocated mainly to food items. The second biggest share of the farm household's expenses goes to education and health (table 43).

Table 43: $\quad$ Farm household's living expenses

\begin{tabular}{llrrr}
\hline & & PU-3 & PU-6 & PU-9 \\
\hline Food & Rs/year & 37,900 & 73,000 & 73,000 \\
Clothing and utilities & Rs/year & 3,000 & 20,000 & 16,000 \\
Education & Rs/year & 3,000 & 5,000 & 16,000 \\
Health & Rs/year & 4,000 & 15,000 & 1,460 \\
Others (e.g. weddings, emergencies, etc.) & Rs/year & 4,790 & 11,300 & 10,646 \\
\hline Total family living expenses & Rs/year & 52,690 & 124,300 & 117,106 \\
\hline
\end{tabular}

Source: Results of the typical farm selected from farm household's survey.

\section{Household and farm resources}

The household resources include the fixed assets in the form of land owned, machinery, building and the livestock herd including the milking and dry herd. The owned land of the selected typical farms is 3, 8 and 25.5 acres for PU-3, PU-6 and PU-9 respectively. The milking animals are 3, 6 and 9 animals on PU-3, PU-6 and PU-9 respectively. Buffalo is a dominating animal in all the three typical farms (table 44).

Table 44: Landholding and farm resources

\begin{tabular}{llrrr}
\hline & & PU-3 & PU-6 & \multicolumn{1}{c}{ PU-9 } \\
\hline Total herd size & nos & 6 & 14 & 21 \\
Milking animal & nos & 3 & 6 & 3 \\
Buffaloes & nos & 2 & 4 & 6 \\
Cows & nos & 1 & 2 & 3 \\
Owned land & acrs & 3 & 8 & 25.5 \\
Farm machinery value & Rs & 24,200 & 400,000 & 822,000 \\
\hline Building and sheds value & Rs & 30,000 & 293,000 & 150,000 \\
\hline
\end{tabular}

Source: Results of the typical farm selected from farm household's survey. 


\section{Household income}

The household income comprises of income from the entire farm i.e. dairy, crop, and other farm and off enterprises. A significant contribution of dairy income is observed in small scale typical farm PU-3, which is highest as 40 percent and lowest as 17 and 19 percent for PU-9 and PU-6 respectively. The small scale farms are more dependent on dairy income as compared to medium and large scale farms.

The highest share of crop income is observed in typical farm PU-9 which is 71 percent and for PU-6 as 67 percent. The large farm types focus more on the crop enterprises. The share of other farm income ranges between 7 to 14 percent with highest in PU-6 and lowest in PU-9 (table 45). This shows the general pattern under mixed cropping system. The crop enterprise is the main focus of large and medium scale farms. Dairy is only seen as a supplement activity to the crop enterprise where it consumes mostly the by products of the crops mainly wheat straw.

Table 45: $\quad$ Household income share from different enterprises

\begin{tabular}{llrrr}
\hline & & PU-3 & PU-6 & PU-9 \\
\hline Off-farm income & Rs/year & 24,000 & 36,000 & 24,000 \\
Farm income & Rs/year & 65,010 & 262,731 & 397,728 \\
Crop & Rs/year & 17,306 & 175,435 & 301,350 \\
Dairy farm & Rs/year & 35,704 & 49,796 & 66,378 \\
Other farm & Rs/year & 12,000 & 37,500 & 30,000 \\
\hline Total household income & Rs/year & 89,010 & 298,731 & 421,728 \\
\hline
\end{tabular}

Source: Results of the typical farm selected from farm household's survey.

The share of farm household's income is distributed among off-farm and farm activities. The highest share of off-farm income is observed as 27 percent in small farm types PU-3. While its share decreases with the increase in size of the farm.

Table 46: Farm household's income share

\begin{tabular}{|c|c|c|c|c|}
\hline & & PU-3 & PU-6 & PU-9 \\
\hline Off-farm income share & $\%$ & $27 \%$ & $12 \%$ & $6 \%$ \\
\hline Crop enterprise share & $\%$ & $19 \%$ & $59 \%$ & $71 \%$ \\
\hline Dairy farm enterprise share & $\%$ & $40 \%$ & $17 \%$ & $16 \%$ \\
\hline Other farm enterprise share & $\%$ & $13 \%$ & $13 \%$ & $7 \%$ \\
\hline
\end{tabular}

Source: Results of the typical farm selected from farm household’s survey. 


\section{Gross margin calculation of dairy enterprise}

The status quo analysis of the typical farms showed that small farms do not feed milk animals with concentrate feed. The concentrate costs are highest in large typical farm-PU9 (table 47). They only rely on feeding the green fodder and the crop by products which are produced from their own farm (HIRASHIMA, 1978).

Table 47: $\quad$ Dairy input costs

\begin{tabular}{llrrr}
\hline & & PU-3 & PU-6 & PU-9 \\
\hline Cost of forage production, purchased fodder & Rs & 2,660 & 13,000 & 35,915 \\
Concentrate fed per day & kg/day & 0 & 1 & 3 \\
Concentrate price & Rs/kg & 1,800 & 25,500 & 10,395 \\
Total feeding costs & Rs/year & 4,460 & 38,500 & 139,865 \\
Vet. and medicines costs & Rs/year & 1,050 & 2,100 & 3,150 \\
Breeding costs & Rs/year & 150 & 300 & 450 \\
Fixed costs & Rs/year & 4,144 & 24,660 & 43,920 \\
\hline Total dairy input costs & Rs/year & 9,804 & 65,560 & 187,385 \\
\hline
\end{tabular}

Source: Results of the typical farm selected from farm household's survey.

The medium type farm supplements the animal feeding with concentrated feed to the lactating animals. On average the medium size farm gives feed about $1 \mathrm{~kg}$ of concentrate in the form of cotton seed cake. The large scale typical farms feed about $3 \mathrm{~kg}$ of concentrate per milking animal as a supplement which helps to achieve higher milk yields.

Milk receipts are the major source of dairy farm income in all three typical farms. The animal sales are the second major source of income after milk sales for all three typical farms under mixed cropping system in Punjab Province. The other dairy returns mainly come from sale of manure or use as farmyard manure (TEUFEL, 2006).

Table 48: Dairy returns

\begin{tabular}{llrrr}
\hline & & PU-3 & PU-6 & PU-9 \\
\hline Milk receipts per year & Rs/year & 23,908 & 70,445 & 69,356 \\
Livestock sales per year & Rs/year & 18,000 & 25,500 & 42,500 \\
Total other dairy returns & Rs/year & 3,600 & 1,500 & 3,500 \\
\hline Total dairy returns & Rs/year & 45,508 & 97,445 & 115,356 \\
\hline
\end{tabular}

Source: Results of the typical farm selected from farm household’s survey.

The gross margin calculations are made by deducting the total dairy costs (mainly the feeding management and husbandry costs) from the total dairy returns (milk receipts, animal sales, other dairy returns) (table 49). 
Table 49: $\quad$ Gross margin of dairy enterprise

\begin{tabular}{llrrr}
\hline & & PU-3 & PU-6 & PU-9 \\
\hline Total dairy returns & Rs/year & 45,508 & 115,356 & 253,763 \\
Total dairy costs & Rs/year & 9,804 & 65,560 & 187,385 \\
\hline Gross margin & Rs/year & 35,704 & 49,796 & 66,378 \\
\hline
\end{tabular}

Source: Results of the typical farm selected from farm household's survey.

\section{Milk production}

The annual milk production of all the three typical farms varies between 3 tonnes in case of PU-3 and 17.5 tonnes ECM ${ }^{33}$ for PU-9 (table 50). The farms can produce higher milk quantities through improving the animal productivity through husbandry, feeding and breeding, etc. The milk yield is very low on small-scale farms due to poor genetic potential of animals along with poor feeding, management and husbandry practices being adopted by the farmers. The large typical farm produces almost double milk yield than the small typical farms. The difference in milk yields is mainly due to better genetic potential of breeds and secondly better feeding and management followed.

Table 50: Milk production of three farms

\begin{tabular}{lllcc}
\hline & & PU-3 & PU-6 & PU-9 \\
\hline Average milk yield of cow & kg/year & 1,350 & 2,160 & 2,340 \\
Average milk yield of Buffalo & kg/year & 1,138 & 1,752 & 2,102 \\
\hline Total milk production per year & \multirow{2}{*}{ tonnes ECM/year } & 2.96 & 9.9 & 17.7 \\
\hline
\end{tabular}

Source: Results of the typical farm selected from farm household's survey.

Buffalo is the main dairy animal found on all three typical farms under the mixed cropping system. Buffalo is a well adapted animal in irrigated region. The milk yield is generally low in non-descriptive breeds. Due to lack of proper health and veterinary care, the small typical farms showed highest mortality rate of calves which is 20 percent as compared to 10 percent in rest of two typical farms. 
Table 51: Herd details

\begin{tabular}{llrrr}
\hline & & PU-3 & PU-6 & PU-9 \\
\hline No of cows & nos & 1 & 2 & 3 \\
No of buffaloes & nos & 2 & 4 & 6 \\
Claves & nos & 2 & 5 & 8 \\
Heifers & nos & 1 & 3 & 4 \\
Mortality rate of calves & $\%$ & $20 \%$ & $10 \%$ & $10 \%$ \\
Mortality rate of heifers & $\%$ & $5 \%$ & $3 \%$ & $3 \%$ \\
\hline Mortality rate of adult animals & $\%$ & $2 \%$ & $1 \%$ & $1 \%$ \\
\hline
\end{tabular}

Source: Results of the typical farm selected from farm household's survey.

Table 52: $\quad$ Livestock sales

\begin{tabular}{lcccr}
\hline & & PU-3 & PU-6 & \multicolumn{1}{c}{ PU-9 } \\
\hline Cows & Rs/year & 3,000 & 6,000 & 9,000 \\
Buffaloes & Rs/year & 7,000 & 14,000 & 21,000 \\
Calves & Rs/year & 8,000 & 22,500 & 36,000 \\
\hline Total livestock sales & Rs/year & 18,000 & 42,500 & 66,000 \\
\hline
\end{tabular}

Source: Results of the typical farm selected from farm household's survey.

The heifers are raised on the farm and are used to replace the low yielding old age animals. The low yielding animals are culled after every 5 years in all the three typical farms. The calculations used a culling rate of $20 \%$ percent. $^{34}$ The male calves are sold for meat purpose on the farm with in first year (table 52).

\section{Home consumption}

The share of dairy in home consumption shows a relatively higher share especially in typical farm PU-6 which is 49 percent followed by small scale typical farm PU-3 as 41 percent and 28 percent for PU-9. This shows that small scale farms produce milk mainly for meeting family consumption and only sell if surplus is left. Similarly the medium size typical farm PU-6 consumes most of the outputs of the dairy enterprise within the home to meet family nutrition needs.

34 The animals are culled after every five years. For revenue calculation purpose the expected revenue from sale of animals is divided into per year which means a cow of Rs 15000, will generate a sales of Rs 3000 per year. 
In volume terms the per capita milk consumption is seen highest in typical farm PU-9 which is $1186 \mathrm{~kg}$ ECM milk and lowest in small typical farm (PU-3) as $250 \mathrm{~kg}$ ECM milk (table 53). The large farms consume milk in liquid form and also prepare various indigenous dairy products. Butter oil is the most commonly prepared product. Besides making oil for cooking purpose, butter oil is also another way to store milk products for longer duration without any requirement of cool chain. Usually the evening milking is used to prepare butter oil and other dairy products (ANJUM et al., 1989; TEUFEL, 2006).

Table 53: Home consumption

\begin{tabular}{llccc}
\hline & & PU-3 & PU-6 & PU-9 \\
\hline Crop output share & $\%$ & $19 \%$ & $14 \%$ & $19 \%$ \\
Dairy output share & $\%$ & $41 \%$ & $49 \%$ & $28 \%$ \\
\hline Per capita milk consumption & Kg ECM /year & 250 & 1,046 & 1,186 \\
\hline
\end{tabular}

Source: Results of the typical farm selected from farm household’s survey.

\subsection{Evaluating Development Interventions}

Through status quo analysis of typical milk production system in Sargodha region under mixed cropping system in Punjab, it is found that generally the small scale farms show the poor picture of lower productivity. The small farms have lower milk yields and the dairy income is lowest as compared to medium and large farm types. The issue of poor productivity results into lower income contribution from the dairy enterprise in the overall farm household's income as compared to the actual potential.

To improve the income of dairying households with low productivity in Punjab, the small scale farm type is selected to evaluate various improvement interventions. Any development strategy proposing intervention for improving the income of dairying households shall consider the situation of the decision makers in these farm types for economic and social reasons. The key to improvement in dairy farm income is the increase in saleable milk. It is important to evaluate that how can improvement be achieved in milk yield through adopting certain production measures.

Through comparison of the farm types in the region and discussion with the experts, a list of various possible development interventions are selected. Out of various options, only four adaptable programs are selected which can generate better returns with minimum external and internal modifications necessary at the farm. The identified development options that are foreseen to have a significant improvement are tested and evaluated through partial budgeting method (NORMAN, 1995). 
The calculations are made by use of the ex-ante simulations method to forecast the improvement in household income. The interventions are adopted under certain preconditions in terms of inputs and adjustments within the farm enterprises and resources in terms of allocation, etc. The related costs and returns are taken into account to measure the differences accordingly.

The typical farm PU-3 is considered as an example and representative of small scale farms in the region. The set of four improvement interventions are evaluated by applying certain modifications on the typical farm. The changes between the existing typical farm PU-3 and the proposed PU-3 farm type are presented. The improvement is reflected both in quantitative terms as an increase in milk production of the farm and in monetary terms as the change in dairy income subsequently leads to household income. The procedure adopted to evaluate the improvement is done by comparing the results of improvement scenario with the baseline farm type PU-3..$^{35}$ The scope and limitations of the proposed interventions are explained below in the subsequent improvement scenario. The situation is explained scenario-wise with key inputs and outputs of the farm which are considered as costs and returns of each intervention.

\subsubsection{Fodder improvement scenario}

Fodder shortage is the major limiting factor of dairy production especially for small scale farm types under mixed cropping system in irrigated Punjab. The milk production potential of cows and buffaloes can not be fully achieved under fodder shortage situation. The new development programs focusing on the regular supply of fodder through improving fodder production and regular availability can make a difference. An improvement in milk production can play a significant role to increase the farm income and achieve the income goal of dairying households.

Typically the shortage of fodder occurs at the ending season of one fodder crop and beginning of the next fodder crop season which is somehow inter-linked with the extreme weather condition both in winter during the months of December /January and summer months of May/June (TEUFEL, 2006). The milk production on small scale farms is severely effected due to shortage of fodder mainly due to poor performance of fodder varieties, lack of production factors availability like irrigation water and fertilizer inputs, etc. at an appropriate time. They grow mainly berseem (Trifolium alexandrium) as a winter fod-

35 The baseline farm is the existing typical farm which is used as a starting point to measure any improvement. The codes used for baseline is PU-3 Baseline, for improvement interventions are as PU-3 Fodder improvement, PU-3 Husbandry improvement, PU-3 Marketing Improvement, PU-3 Breed Improvement and PU-3 Herd Size improvement. 
der and millets or local sorghum as summer fodder. In general, the farmers stick to their old traditions of growing those fodder crops which are grown since decades. They lack awareness/knowledge about the other possible alternatives. They tend to be risk averters and adopt those strategies that do not require any additional costs.

The proposed fodder development scenario will be helpful to overcome this shortage through timely planning and planting of appropriate fodder crops to fill the gap of shortage. Through consulting the literature and analysing the better situation on the progressive farm types in the area, the development intervention is proposing improvement in both winter and summer fodder crops. The area under fodder cultivation remains constant. The only difference is in the choice of fodder crops.

The intervention is proposed to replace the winter fodder crop of berseem (Trifolium alexandrium) with oat (Avena sativa). ${ }^{36}$ The selection of oat fodder will help to achieve more quantities of green fodder (double forage yields as compared to berseem) and better nutrition.

The fodder development intervention also proposes to replace the summer fodder crop of millets and other fodder crops with the better yielding hybrid sweet sorghum (more than double forage yields compared to millets). This will help to attain better access of fodder by the dairy animals and overcome the shortage situation.

Both of the proposed fodder crops of oat and hybrid sorghum have longer vegetation period and can bear cold and heat stress in winter and summer season better than berseem and millets respectively. In quantitative terms the oat and hybrid sorghum can produce a forage yield of 49 and 50 tonnes per acre through improved management, selection of right seed, timely sowing, improving fertilizer application mainly urea and irrigating crop at the right time. These new crops can be harvested 3 to 4 times in a season (table 55).

The result of partial budgeting analysis shows that this improvement will bring about an increase in cost of forage production by 34 percent which accounts to Rs 915 per year (from Rs 2660 to Rs 3575). This intervention will help to overcome the fodder shortage. The fodder yields are assumed to increase by 53 percent in winter fodder and 25 percent in summer fodder crops.

36 Oat (Avena sativa) has become a very important fodder crop in the past few years. Previously it was sown in the military farms and government research stations but, with the introduction of highyielding multi-cut cultivars in the late eighties the situation changed dramatically and Oat has become a major forage and now figure largely in the green fodder and also sold as hay to urban markets. Oat provides a high quality feed and is high yielding. It continues to grow at lower temperatures than does berseem so it can provide feed in the winter gap when prices are high. Like berseem it is mostly grown in irrigated regions. 
Table 54: Inputs requirement of winter fodder crop-oat

\begin{tabular}{|c|c|c|c|c|}
\hline & & PU-3 baseline & $\begin{array}{l}\text { PU-3 Fodder } \\
\text { Improvement }\end{array}$ & $\begin{array}{c}\text { Differences } \\
(+/-)\end{array}$ \\
\hline Seed & Rs & 720 & 1,000 & 280 \\
\hline Seed bed preparation & Rs & 1,000 & 1,200 & 200 \\
\hline Fertilizer & Rs & 1,250 & 1,600 & 350 \\
\hline Irrigation & Rs & 1,000 & 1,000 & 0 \\
\hline Pesticides & Rs & 0 & 500 & 500 \\
\hline Total input costs/acre & Rs/acre & 3,970 & 5,300 & 1,330 \\
\hline
\end{tabular}

Table 55: $\quad$ Inputs requirement of summer fodder -hybrid sorghum

\begin{tabular}{llccc}
\hline & PU-3 baseline & $\begin{array}{c}\text { PU-3 Fodder } \\
\text { Improvement }\end{array}$ & $\begin{array}{c}\text { Differences } \\
(+/-)\end{array}$ \\
\hline Seed & Rs & 900 & 1,500 & 600 \\
Seed bed preparation & Rs & 1,000 & 1,000 & 0 \\
Fertilizer & Rs & 550 & 800 & 350 \\
Irrigation & Rs & 250 & 400 & 150 \\
\hline Total input costs/acre & Rs/acre & 2,700 & 3,700 & 1,100 \\
\hline
\end{tabular}

As a result of availability of fodder round the year, the dairy animals have the access to sufficient fodder. The regular availability of fodder and better nutrition will help to improve the animal health. The fodder yield improved from 16 tonnes to 24.5 tonnes per acre.

The improvements in lactation days occur in buffaloes from 285 day to 290 days. The overall milk production of the whole farm is increased by 13 percent from 2.9 tonnes to 3.4 tonnes ECM. ${ }^{38}$

Table 56: Post intervention situation: increase in fodder yield

\begin{tabular}{lcccc}
\hline & PU-3 baseline & $\begin{array}{c}\text { PU-3 Fodder } \\
\text { Improvem ent }\end{array}$ & \% Increase \\
\hline $\begin{array}{l}\text { Winter fodder yield } \\
\text { (berseem replaced with oats) }\end{array}$ & tonnes/acr & 16 & 24.5 & $53 \%$ \\
\hline $\begin{array}{l}\text { Summer fodder } \\
\text { (millets/sorghum replaced with hybrid sorghum) }\end{array}$ & tonnes/acr & 14 & 15.5 & $25 \%$ \\
\hline
\end{tabular}

37 Tonnes per acre yield is converted to the area of the fodder i.e. yield for 0.5 acre, etc.

$38 \quad$ The calculations are made on the basis of the literature and the expert opinion discussed during panel discussions. 
Table 57: Post intervention situation: milk yield and farm milk production

\begin{tabular}{llccr}
\hline & & PU-3 baseline & $\begin{array}{c}\text { PU-3 Fodder } \\
\text { Improvement }\end{array}$ & \% Increase \\
\hline Lactation length of buffalo & days & 285 & 290 & $2 \%$ \\
Cow milk yield per lactation & Kg ECM & 1,350 & $1,552.5$ & $15 \%$ \\
Buffalo milk yield per lactation & Kg ECM & 1,170 & $1,345.5$ & $15 \%$ \\
\hline Total milk produced per year & tonnes ECM & 2.9 & 3.3 & $13 \%$ \\
\hline
\end{tabular}

The fodder improvement helps to improve the farm production that leads to increase the income from the milk sales. The farm can sell more milk. The average income increase due to milk increase is Rs 5000 per year. The increase in animal health condition is also helpful to fetch higher prices from livestock sales especially the calves and cull cows. This additional increase in livestock income is about Rs 2000.

The dairy income is increased by 20 percent transforming into an increase of 11 percent in overall farm income. The fodder intervention can play an important role to improve the income of the dairying farm households by 8 percent (table 58).

Table 58: Post intervention situation: household income

\begin{tabular}{llcc}
\hline & & PU-3 baseline & $\begin{array}{c}\text { PU-3 Fodder } \\
\text { Improvement }\end{array}$ \\
\hline Off farm & Rs/year & 24,000 & 24,000 \\
Other farm & Rs/year & 12,000 & 12,000 \\
Crop & Rs/year & 17,306 & 17,306 \\
Dairy farm & Rs/year & 35,704 & 42,766 \\
Farm income & Rs/year & 65,010 & 72,072 \\
\hline Total farm households income & Rs/year & 89,010 & 96,072 \\
\hline
\end{tabular}

There are certain limitations ${ }^{39}$ of the fodder improvement intervention which has to be kept in mind before launching any development program focusing this area. These are availability of quality seed of oat and hybrid sorghum varieties, availability of urea fertilizer, and irrigation water in time and raise awareness about the advantage.

39 One potential constraint in getting the oat varieties into large-scale cultivation is availability of tested, proven cultivars of oat by the provincial fodder research institute (BHATTI and KHAN, 1996). The introduction and development of fodder new oat varieties as a major cash crop in Pakistan (DOST, 2002). 


\subsubsection{Animal husbandry and health improvement scenario}

Lack of adoption of appropriate husbandry and health practices leads to lower milk production and high losses due to mortality rate which is quite high in calves. This problem is often observed as a weak part of the small scale farms due to lack of awareness and access to technology. Although the awareness programs are part of the provincial and federal government's development agenda in Pakistan but the real impact is negligible. Illiteracy and economic limitations are named as possible reasons of low acceptance (HASNAIN et al., 2006; TEUFEL, 2006).

Adopting appropriate husbandry and health measures can lead to reduce the inter-calving intervals, reducing dry periods, lowering down the calves and adult mortality rates, etc. Currently the calf mortality is at a very high level with average of $20 \%$ in small scale farms. The calves play a substantial role to maintain /increase the herd size. They also contribute significantly in the income from sale of livestock animals. Due to lack of assurance in adopting new technologies, small farmers are hesitant to take new initiatives by making new investments. The small scale farms tend to be risk avoiders naturally (STAAL et al., 1996).

The proposed husbandry and health improvement interventions focus mainly on timely heat detection and inseminating animals with quality insemination on one hand and controlling the calves' mortality rate on other hand through preventive vaccination. The existing farm PU-3 baseline shows a dry percentage of $37 \%$ in cows and $49 \%$ in buffaloes which is the major impeding factor of lower productivity of animals on small scale animals (table 59). All this is due to lack of animal husbandry measures being followed on the farm. This strategy is helpful to decrease the percentage of dry herd to $23 \%$ overall. The annual milk production of the herd is automatically increased with more animals in milk.

Table 59: $\quad$ Post intervention situation: lactation and dry days

\begin{tabular}{llrr}
\hline & & Cow & Buffalo \\
\hline Lactation length & days & 300 & 285 \\
Dry period & days & 120 & 160 \\
Dry period in life time & days & 840 & 1,120 \\
Inter-calving interval & months & 14 & 15 \\
\hline Share of dry animals & $\%$ & $35 \%$ & $49 \%$ \\
\hline
\end{tabular}


The certain health improvement measures are adopted which are vaccinating and deworming of calves at an early stage. This costs about Rs 300 additional per year for the entire herd. It will be helpful to decrease the mortality rate from 20 to 5 percent in calves and 6 percent in heifers and adult animals to 2 percent.

By adopting Husb \&Hlth Imp ${ }^{40}$ improvement strategy, the breeding costs will increase from Rs 50 per animal to Rs 150 per animal per year (table 60). The additional investment is about Rs 600 per year. The additional costs on husbandry and health measures are helpful to control the mortality rate especially in calves from 20 percent to 5 percent and similarly in heifers from 5 percent to 2 percent.

Table 60: Post intervention situation: health and breeding costs

\begin{tabular}{lccc}
\hline & & PU-3 baseline & PU-3 Husb. \&HIth. Imp \\
\hline Vet. and medicines costs & Rs/year & 1,050 & 1,350 \\
Breeding costs & Rs/year & 150 & 450 \\
\hline
\end{tabular}

Table 61: Post intervention situation: mortality rate

\begin{tabular}{lccc}
\hline & & PU-3 baseline & PU-3 Husb. \&HIth. Imp. \\
\hline Calves & nos & 2.0 & 3.0 \\
Heifers & nos & 1.0 & 2.0 \\
Mortality rate of calves & $\%$ & $20 \%$ & $5 \%$ \\
\hline Mortality rate of heifers & $\%$ & $5 \%$ & $2 \%$ \\
\hline
\end{tabular}

By educating the farmers about the reproductive cycle of the female animals, early heat detection can be utilized for timely mating either through natural method or through artificial insemination. The timely heat detection ${ }^{41}$ and impregnation can help to achieve early pregnancy of the female animals. Through vigilant management, the small farms can easily reduce the dry period of 120 days in cows to 60 days and 90 days or more to 70 days in buffaloes. The intervention is helpful to reduce the dry herd to 18 percent in cows and 28 percent in buffaloes (table 62). This will automatically reduce the inter-calving interval from 14 months to 12 months in cows and from 15 months to 13 months in buffaloes.

40 Husbandry and health improvement intervention.

41 The farmer is watching closely the behaviour of the animal, e.g. more active behaviour, or jumping on fellow animals. Teasers are also used for heat detection. 
Table 62: $\quad$ Post intervention situation: dry and lactation period

\begin{tabular}{llrr}
\hline & & Cow & Buffalo \\
\hline Dry period & days & 60 & 90 \\
Dry period in life time & days & 420 & 630 \\
Inter-calving interval & months & 12 & 13 \\
\hline Share of dry animals & $\%$ & $18 \%$ & $28 \%$ \\
\hline
\end{tabular}

By adopting the simple management skills, the inter-calving interval can be reduced by 14 percent in cows and 16 percent in buffaloes. The husbandry and health improvement scenario is helpful to achieve higher milk production per year as compared to the baseline. The inter-calving interval has shown a significant improvement of 35 percent in annual milk yield per animal which ultimately increased the total herd milk production from 2.9 tonnes to 3.9 tonnes ECM per year.

The milk receipts have increased significantly by 59 percent compared to the baseline. The non milk returns which mainly come from livestock sales have improved by 35 percent which is mainly driven by controlling the mortality rate of calves from 20 percent to 5 percent (table 63).

Table 63: Post intervention situation: milk yield and livestock sales

\begin{tabular}{llcc}
\hline & & PU-3 baseline & PU-3 Husb. \&HIth. Imp. \\
\hline Cows & $\mathrm{kg}$ & $1,350.0$ & $1,620.0$ \\
Buffaloes & $\mathrm{kg}$ & 959.7 & $1,366.6$ \\
Total milk produced per year & tonnes ECM & 2.9 & 3.9 \\
Milk receipts per year & Rs/year & 23,908 & 38,022 \\
Calves sales & Rs/year & 8,000 & 14,250 \\
\hline Total livestock sales & Rs/year & 18,000 & 24,250 \\
\hline
\end{tabular}

The dairy income is increased by 55 percent as a result of the husbandry and health scenarios mainly due to improvement made by reducing the dry period and inter-calving interval in cows and buffaloes. This will also help to achieve higher number of animals in milk. The farm income has shown a significant improvement of 30 percent as a result of improvement in health and husbandry management practices (table 64). The final calculations of husbandry and health intervention showed an improvement of 22 percent in the farm household's income (increase from Rs 89,000 to Rs 109,000). 
Table 64: $\quad$ Post intervention situation: household income

\begin{tabular}{lccc}
\hline & & PU-3 baseline & PU-3 Husb. \&Hlth. Imp. \\
\hline Off-farm & Rs/year & 24,000 & 24,000 \\
Other farm & Rs/year & 12,000 & 12,000 \\
Crop & Rs/year & 17,306 & 17,306 \\
Dairy farm & Rs/year & 35,704 & 55,468 \\
Farm income & Rs/year & 65,010 & 84,774 \\
\hline Total farm households income & Rs/year & 89,010 & 108,774 \\
\hline
\end{tabular}

\subsubsection{Breed improvement scenario}

The natural potential of most of the milking herd in small farms is very low as observed in the survey of dairying households under mixed cropping system in Punjab. The animal breeds are either used as a dual purpose breed (using for milking and ploughing in the past) or raised for meat purpose. Selection and crossing are the two important ways to improve any breed for milk production. Most of the herd on the farm is kept for social and prestige reasons. The concept of culling low yielding animals is almost negligible in small scale farms due to small herd and social reasons. Traditionally the farm households have social and moral sentiments with cows and buffaloes and stick to the norm irrespective of lower productivity.

The breed improvement intervention is proposed to replace the poor genetic potential animals with better yielding ones. The procedure is followed through selection and crossing over a period of time. The low yielding animals are replaced with better yielding animals which are crossbred or high yielding domestic breed of Sahiwal cows.

The proposed strategy assumes that one high yielding animal each from cow and buffaloes breed comes into the herd after 3 years. Under the traditional system, the average milk yield of cow is $1350 \mathrm{~kg}$ per lactation and $1170 \mathrm{~kg}$ for buffaloes. With the breed improvement, the milk yields in cows ${ }^{42}$ can be improved more than double to produce $3120 \mathrm{~kg}$. In case of buffaloes $^{43}$ the milk yield is almost double as $2170 \mathrm{~kg}$ milk per lactation as a result of selective breeding (table 65). The dry days are reduced accordingly for the high yielding animals from 120 days under traditional system to 60 days in cows and from 90 days in buffaloes to 75 days after achieving improvement.

42 Data from well managed herd of local cow breed of Sahiwal, 310 cows kept at Military dairy farm, Okara showed a maximum productivity 7750 Ibs of milk per lactation (SIKKA,1931).

43 The buffalo breed Nilli-Ravi has a yield potential of producing $30 \mathrm{~kg}$ of milk per day with better feeding. 
Table 65: Post intervention situation: milk yield

\begin{tabular}{llcr}
\hline & & PU-3 baseline & PU-3 Breed Imp. \\
\hline Cow & & & \\
First 3 months x 2 times a day & Kg/day & 6 & 14 \\
Second 3 months x 2 times a day & Kg/day & 6 & 8 \\
Last 4 months, milking 2 times a day & Kg/day & 3 & 3,120 \\
Milk yield per lactation & kg/lact. & 1,350 & \\
\hline Buffalo & & & 10 \\
First 3 months x 2 times a day & Kg/day & 5 & 5 \\
Second 3 months x 2 times a day & Kg/day & 4 & 2,170 \\
Last 4 months, milking 2 times a day & Kg/day & 4 & 1,170 \\
Milk yield per lactation & kg/lact. & & \\
\hline
\end{tabular}

The animal productivity is very much dependent on the animal feed intake. Green fodder feeding can meet the animal feed requirement for marginal production only due to lack of sufficient energy availability. Accordingly the high yielding animals require more dry matter intake to fulfil their body energy requirements. For getting better yields, the animal needs an additional supplement feed of high energy concentrate. Similarly the health and breeding expenses are increased as well for adaptation of this strategy.

Under the traditional system the milking animals are only dependent on feeding green fodder and roughages. They are not given any supplement feed. By adopting the breed improvement strategy, the high yielding animals are fed with $3 \mathrm{~kg}$ of concentrate per day. The concentrate feed consists of cotton seed cake and mixed ration of various grains. The price of the feed is Rs 14 per $\mathrm{kg}$ (Rs 14,000 / tonnes).

For achieving better results of the breeding strategy the farm is supposed to make extra efforts to maintain good health of animals. The good health can be managed through balanced feed and taking care of all the diseases. The most common diseases in the area are mastitis, stomach disorders, foot and mouth and rinder pests, and some skin diseases etc. (AHMAD et al., 2000).

There is a need to adopt a prophylactic vaccination program against epidemic diseases which affects the animal health and milk production very badly. The preventive steps are carried out in the adult and small animals to control mortality rate as well. The veterinary and medication costs are increased almost three times higher. The crossing of the female animals is done with the high yield exotic/ better progeny domestic breeds. The additional breeding costs are incurred on buying the semen and paying for the services of the animal technician. 
The overall costs of implementing the breeding strategy will have additional impact on the farm input costs. The total farm input costs will increase by almost 370 percent, which mainly comes from the additional feeding required for the high yielding animals.

Table 66: Post intervention situation: feeding, health and breeding costs

\begin{tabular}{llcr}
\hline & & PU-3 baseline & PU-3 Breed Imp. \\
\hline Concentrate feed/day & kg/day & 0 & 3 \\
Total feed cost of the whole farm & Rs/year & 1,800 & 3,465 \\
Vet. and medicine costs & Rs/year & 1,050 & 3,000 \\
Breeding costs & Rs/year & 150 & 1,500 \\
\hline Total dairy input costs & Rs/year & 9,804 & 45,954 \\
\hline
\end{tabular}

The breed improvement makes a significant increase in the milk yield of cows and buffaloes that contribute to increase the over milk production of the herd. This increase is 58 percent from 2.9 tonnes to 7.1 tonnes of ECM milk per annum (table 67). The income from dairy will increase mainly from sale of milk which is almost four times higher than the traditional system. The second highest returns of dairy enterprise come from sale of livestock animals which are mainly the additional calves alive per year due to improvement in inter-calving interval and decrease in mortality rate of calves and heifers. The income from livestock sales is almost double due to improvement in breeding.

Table 67: Post intervention situation: dairy returns

\begin{tabular}{llcr}
\hline & & PU-3 baseline & PU-3 Breed Imp. \\
\hline Total milk produced & tonnes/year & 2.9 & 7.1 \\
Milk receipts & Rs/year & 23,908 & 80,482 \\
Cull cow sales & Rs/year & 3 & 6,000 \\
Cull buffaloes sales & Rs/year & 7,000 & 14,000 \\
Calve sales & Rs/year & 8,000 & 14,250 \\
\hline Total annual livestock sales & Rs/year & 18,000 & 34,250 \\
\hline
\end{tabular}

The breed improvement strategy has shown a significant improvement in the income from the dairy enterprises which have increased by 103 percent. The contribution of dairy income is doubled in the total farm income from 40 percent to 81 percent which is highest as compared to all other improvements carried out on the farm. The farm household's income has shown a significant improvement with an increase of 56 percent overall (table 68). 
Table 68: $\quad$ Post intervention situation: household income

\begin{tabular}{lccc}
\hline & & PU-3 baseline & PU-3 Breed Imp \\
\hline Off-farm & Rs/year & 24,000 & 24,000 \\
Other farm & Rs/year & 12,000 & 12,000 \\
Crop & Rs/year & 17,306 & 17,306 \\
Dairy farm & Rs/year & 35,704 & 72,378 \\
Farm income & Rs/year & 65,010 & 101,684 \\
\hline Total farm households income & Rs/year & 89,010 & 125,684 \\
\hline
\end{tabular}

\subsubsection{Perceived higher milk prices-marketing scenario}

If farms in rural areas get linked with market they can get better returns from their outputs without making further efforts in increasing their production, especially the small dairy farmers who produce a perishable product i.e. milk, they do not have strong negotiation power. They need a better mechanism of marketing their products to fetch better prices. The dominance of informal milk marketing systems, characterized by several middlemen is the major cause of lower milk prices and in-efficiencies. The payment system of informal middlemen is very unreliable. Therefore there is a need to develop formal milk marketing channels. Since the processing sector is very insignificant as compared to informal system with less than 10 percent market share.

Under these circumstances the small farmers who produce lower volumes of milk have difficulty to access the formal market channels. On average the farmers get less than 50 percent of the price which consumers pay for the milk. Most of the margins are harvested by the middlemen due to weak linkage of the producers with the markets.

The proposed intervention assumes that if a development scenario/ program focusing on dairy development in the region provide an access to a milk cooling centre in the village to purchase fresh milk and sell it to the formal market i.e. milk processors, the farmers can get better price. We have considered a higher perceived market price of milk as 15 percent higher as compared to the prevailing price in the village.

Table 69: $\quad$ Post intervention situation: milk price

\begin{tabular}{llcc}
\hline & & PU-3 baseline & PU-3 Marketing \\
\hline Cow milk price & Rs/kg & 14 & 18 \\
Buffalo milk price & Rs/kg & 18 & 20 \\
\hline Corrected milk price & Rs/kg ECM & 13.77 & 16.35 \\
\hline
\end{tabular}


By adopting the direct marketing strategy of selling milk to the milk collection centre, the male family member transports the milk to the nearest milk collection centre. The farm spends an additional cost on transporting the milk from the farmstead to the milk cooling centre which is about $2 \mathrm{~km}$ away. The average daily cost on transporting the milk from the farm to the milk centre is Rs 10 (table 71).

Table 70: Post intervention situation: transport costs for marketing milk

\begin{tabular}{llcc}
\hline & & PU-3 baseline & PU-3 Marketing \\
\hline Additional transport costs/year & Rs/year & 0 & 3,000 \\
Total dairy input costs & Rs/year & 9,804 & 12,804 \\
\hline
\end{tabular}

The farm returns calculations are made on the perceived higher milk price and showed that there is no significant improvement achieved in small scale farms due to small volumes of production. This strategy will result into increase in dairy income by only 4 percent. The over all farm households income is improved by 2 percent only with this intervention (table 71).

Table 71: Post intervention situation: perceived higher milk price

\begin{tabular}{lccc}
\hline & & PU-3 baseline & PU-3 Marketing \\
\hline Off-farm & Rs/year & 24,000 & 24,000 \\
Other farm & Rs/year & 12,000 & 12,000 \\
Crop & Rs/year & 17,306 & 17,306 \\
Dairy farm & Rs/year & 35,704 & 37,187 \\
Farm income & Rs/year & 65,010 & 66,493 \\
\hline Total farm households income & Rs/year & 89,010 & 90,493 \\
\hline
\end{tabular}

\subsubsection{Comparison of the improvement interventions}

The individual improvement interventions are already described with their impact in section 4.4.1 to 4.4.4. Here a comparison is drawn among the four evaluated interventions. The analysis showed that the breed improvement scenario leads to the highest dairy returns which are three times higher than the status quo situation of small typical farm PU-3. The breeding scenario is based on the improvement in genetic potential of the milking animals through cross breeding and selection of the high yielding animals. The milk yield in cows is improved from $1350 \mathrm{~kg}$ to $3120 \mathrm{~kg}$ per lactation. While the improvement of milk yield in buffaloes is from $1170 \mathrm{~kg}$ to $2170 \mathrm{~kg}$ per lactation. The improvement in milk yield is possible with better breed and feed accordingly. 
The improvement in total herd production is seen highest with breed improvement scenario which increased from 2.9 tonnes to 7.1 tonnes ECM followed by 4 tonnes ECM through animal husbandry and health improvement.

The dairy input costs are higher for breeding scenario which requires better feeding mainly in the form of concentrate. The gross margin analysis of the dairy enterprise showed that the highest margin is observed for this scenario followed by animal husbandry (table 72).

Table 72: $\quad$ Post intervention situation: comparison of scenario outputs

\begin{tabular}{|c|c|c|c|c|c|c|}
\hline & & PU-3 Baseline & $\begin{array}{l}\text { PU-3 Fodder } \\
\text { Improvement }\end{array}$ & $\begin{array}{c}\text { PU-3 Husb. \& } \\
\text { Hlth. Improvement }\end{array}$ & $\begin{array}{l}\text { PU-3 Breed } \\
\text { Improvement }\end{array}$ & PU-3 Marketing \\
\hline Total dairy returns & Rs/year & 45,508 & 53,485 & 65,872 & 118,332 & 49,991 \\
\hline Dairy input costs & Rs/year & 9,804 & 10,719 & 10,404 & 45,954 & 12,804 \\
\hline Gross margin dairy & Rs/year & 35,704 & 42,766 & 55,467 & 72,378 & 37,187 \\
\hline Total milk produced on the farm & tonnes/year & 2.96 & 3.40 & 4.00 & 7.10 & 3.00 \\
\hline
\end{tabular}

Finally the outcome of the improvement interventions is transformed into the household income. The household income is mainly driven by the increase in farm or off-farm income. By adopting dairy improvement interventions, the major improvements are seen in the dairy enterprise while all other enterprises are considered to remain constant. As a general preference all the conflicts are avoided among the enterprises to evaluate the impact of individual interventions.

The dairy income has showed an increase of 4 to 103 percent among all the four proposed interventions. The highest improvement in dairy income is observed from the breed improvement intervention that helped to increase the dairy farm income from Rs 36000 to Rs 72000. The second highest improvement in dairy income is observed from the husbandry and health interventions that helped to reduce the mortality rate of the calves and also improved the animal health to bring down the inter-calving interval to 12 months in cows and 13 months in buffaloes.

Due to breed improvement intervention, the farm income showed the similar trend like the dairy income with highest increase of 56 percent as compared to the baseline farm. The household income is increased by 2 to 41 percent among all the interventions with highest as 41 percent with the breed improvement intervention (table 73). 
Table 73: $\quad$ Post intervention situation: household income comparison

\begin{tabular}{lcccccc}
\hline & & PU-3 Baseline & $\begin{array}{c}\text { PU-3 Fodder } \\
\text { Improvement }\end{array}$ & $\begin{array}{c}\text { PU-3 Husb. \& } \\
\text { Hlth. Improvement }\end{array}$ & $\begin{array}{c}\text { PU-3 Breed } \\
\text { Improvement }\end{array}$ & PU-3 Marketing \\
\hline Off farm & Rs/year & 24,000 & 24,000 & 24,000 & 24,000 & 24,000 \\
Other farm & Rs/year & 12,000 & 12,000 & 12,000 & 12,000 & 12,000 \\
Crop & Rs/year & 17,306 & 17,306 & 17,306 & 17,306 & 17,306 \\
Dairy farm & Rs/year & 35,704 & 42,766 & 55,468 & 72,378 & 37,187 \\
Farm income & Rs/year & 65,010 & 72,072 & 84,774 & 101,684 & 66,493 \\
\hline Total farm households income & Rs/year & \multirow{2}{*}{89,010} & 96,072 & 108,774 & 125,684 & 90,493 \\
\hline
\end{tabular}

In the end, a final comparison is made for households income calculated as per capita income as a result of various interventions. This will help to make a quick comparison on the basis of improvement in per capita income. The household income is calculated in terms of per capita income per day. All the family members of the household are converted into adult man equivalent to use in per capita calculation. The per capita income is benchmarked with the world bank poverty line (US \$ 1 per day, minimum income required to live) to see if the typical farm (small-scale farms) can come out of poverty circle by adopting the most appropriate farm strategies.

The results are presented in the form of a bar chart that can help the decision makers / researchers to understand the differences quickly (figure 13). It is observed that the per capita income of the existing small scale typical farm PU-3 is 0.83 which is about 17 percent below the international poverty line. With current situation the dairying household of small scale farm is not able to maintain a minimum standard of life which was obvious from the results of the survey.

By comparing all the four interventions, it is found that only two interventions of breed improvement and animal husbandry and health improvement are able to increase the productivity of small scale farms. The bars crossing the poverty line are considered necessary that will help to achieve the objectives to increase income of dairying households in Punjab.

The breed improvement intervention showed a significant improvement of 18 percent. The outcome of this analysis points out the important areas that need improvement i.e. breed improvement, animal husbandry and health. These programs have the probability to perform better with higher returns as compared to other programs. Since breed improvement is the key area that needs a special attention for any dairy development strategy to be successful to increase milk production and bring prosperity in the region. 
Figure 13: Comparison of improvement interventions as per capita income per day

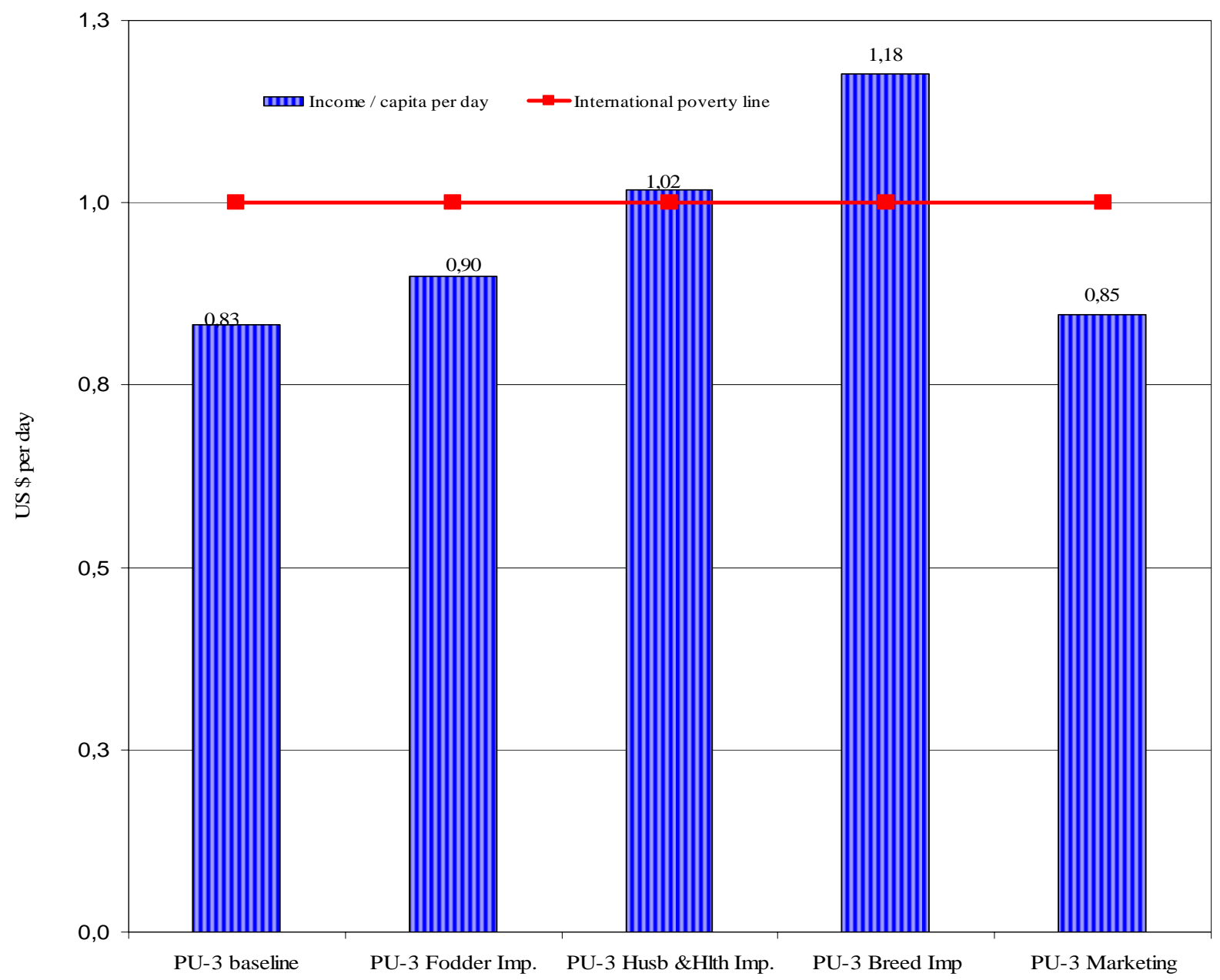




\section{Conclusion}

To understand milk production in Pakistan, the Punjab province is selected. The survey is conducted from 36 farm households from Sargodha district under mixed cropping system from irrigated region of Punjab. The farm types are classified on natural groups of small, medium and large scale depending on the size of land holding. It is found that dairy is an important part of rural farm household to produce milk for the family consumption and source of generating income through sale of milk and livestock animals in all three farm types. The dairy enterprise acts as a source of subsistence in small-scale farms which draws about 40 percent of their household income from it. Dairy farming is not carried out as a specialized, independent enterprise in rural areas but rather as a part of main crop farming activities. The dairy animals are dependent on crops for feeding resources. They are mainly fed with green fodder and by products of the main crops e.g. wheat straw, etc.

The descriptive analysis of the farm households showed 56 percent of the farm households are small scale with land holding of less than 10 acres and keep on average 3 milking animals. The small scale farm types face issues of low productivity mainly due to poor genetic potential of milking animals, poor feeding, husbandry and management practices. They have enough labour to work on the farm but the labour productivity is low due lower milk production.

The medium and large scale farm types are more dependent on crop enterprise and use dairy mostly for home consumption. The share of dairy in household income is below 20 percent both in medium and large scale farm types. Dairy is not considered as a commercial activity on these farm types. The animal productivity is better in medium and large farm types due to better breeds and better feeding but they still have large room for improvement in productivity.

The off-farm income employment opportunities in the area are not so high and people go to urban areas to seek jobs. Dairy provides an alternate source of employment in rural areas and helps to fight against poverty. Future development in dairy will strengthen these farm types better, provided technology measures assure linkage with the market to improve productivity.

The analysis of the cross sectional survey proved that the household owned resources of land, family labour and capital, can be utilized to increase the household income through improving the dairy productivity. For improving the income of dairying household, four improvement interventions are evaluated in the study which is fodder, husbandry \& health, breed and marketing improvement. The estimates of costs and returns of the interventions are calculated through use of partial budgeting technique. The analysis shows that the breed improvement intervention has the highest impact on the dairy income. It 
shows an increase of 38 percent with improvement of US\$ 0.35 in the per capita income from US\$ 0.83 in baseline to US\$ 1.18. It brings the highest dairy returns which are three times higher than the status quo situation of small typical farm PU-3. The breeding scenario is based on the improvement in genetic potential through crossing and selection of high yielding animals. The milk yield is improved more than double in cows and almost two times in buffaloes. It needs additional costs on buying feeding resources in the form of concentrates and extra health measures. The other three scenarios of husbandry \& health, fodder and marketing interventions showed an increase in per capita income by 21 , 7 and 2 percent respectively.

To achieve the objective of understanding the economic situation of small scale farm types a thorough approach has been followed to calculate appropriate costs and returns by considering all the cash and non-cash costs and returns but still there is need to improve the method dealing with multiple outputs from the crop e.g. wheat grain and straw and similarly for sugar cane tops, etc. for allocation of precise costs. 


\section{Summary}

The dairy farming plays an important role to fulfil the nutritional needs of the family and generate income for the farm households in Pakistan. The aim of this research work is to develop an analytical framework for status quo analysis of milk production situation in Pakistan and evaluate the impact of various improvement interventions on the income of farm households involved in dairying. The outcome of this research work will be helpful to find appropriate solutions to facilitate the decision makers and researchers in decision making to improve the income of the household through dairying.

To achieve the goal of understanding the farm households involved in milk production in Pakistan, the region of Punjab is selected. The largest part of milk (about 70 percent) produced in Punjab is coming from the irrigated region under mixed cropping system (wheat is a major crop grown in rotation with cotton and rice). Due to geographical importance and representative of mixed cropping system under irrigated Punjab, the district Sargodha is selected for data collection. The data was collected from two villages through a cross sectional survey of 36 randomly selected farm households having land in winter 2005. Two types of questionnaires are used for collecting data, first questionnaire is used for collecting general information about the characteristics of dairying households and the second questionnaire is used for collecting detailed data about the milk production on the typical farms.

The outcome of the sampled survey are presented in the form of descriptive analysis by presenting case studies, classification of farm types and setting up typical farms. The result of survey is presented in the form of mean, standard deviation, minimum and maximum of important parameters. The comparison is made among the three different farm types. The concept of typical farm is used to identify three typical farms representing all farm types for status quo analysis of milk production in the region. Finally one farm type is identified which faces low productivity in the region and selected to evaluate the improvement interventions.

The farm types are grouped on the basis of land cultivation (both owned and rented) into small, medium and large scale farm types. The land holding varies from 1 to 10 acres, 10 to 20 acres and more than 20 acres for small, medium and large scale farm types. The herd size varies for all farm types from 3 to 10 milking animals. All the three farm types showed considerable differences concerning milk production, such as resource base, production pattern and linkage with the market, etc. They differ mainly in annual milk production, home consumption and milk sales etc.

The small scale farm type represents 56 percent of the sample population. The average milking herd is 3 animals. Dairying is not the specialized enterprise but acts as a partial or 
supplement activity to crop farming. Milk sales provide a regular source of income for the family and act as source of subsistence in small scale farm types. The sale of animals at times of emergency helps the family to meet the cash needs. The dairy animals are mostly fed with the crop residues that come from the main crops e.g. wheat straw, sugar cane tops, rice hay, along with green fodder. Fodder availability round the year is a major concern that hampers the animal productivity on small scale farm types. The housing condition of the farms does not protect animals against the harsh weather conditions which results in higher mortality rate in calves. The animal health conditions are also affected on the farm due to lack of feeding and health care measures. The milking animals are mostly local breeds with low yielding potential, so the milk productivity is very poor due to all these factors. The small scale farm type sells about 60 percent of its total production and consumes 40 percent for family consumption. The small scale farms derive more than 40 percent of their household income share from dairy enterprise.

The medium size farm types represent 28 percent of the sample population in this study. For this farm type, the farm households have on average 14 acres of land. They keep on average six milking animals. The highest number of cows is observed in medium scale farm type. More than 70 percent of the milk produced is consumed at home. They sell on average 22 percent of the total milk produced. The contribution of dairy enterprise income is 20 percent where as the off-farm and crop enterprise have a share of 30 and 48 percent respectively in the over all household income.

The large-scale farm types are 14 percent of the sample population in this study. The average land holding is 37 acres and keep 10 milking animals. This farm type is mainly crop focused due to large landholding but keeps dairy animals as a supplement activity to produce milk for the home consumption and sells if surplus left. Their focus is not fully commercial for dairy purpose. They sometimes keep a large herd which is less productive but it reflects more a status symbol and a sign of prestige in rural areas under mixed farming system. Family labour is not fully engaged in dairy activities and they depend more on the hired labour. The contribution of crop enterprise takes a lead with a share of 65 percent while dairy and off-farm enterprises have a share of 17 and 18 percent respectively in the over all household income.

The status quo analysis of three typical farms PU-3, PU-6 and PU-9 is carried out to explain the situation of milk production in the region. The results of the typical farm are similar to the results of the descriptive analysis. The income situation analysis is done by using the partial budgeting technique. It is found that dairy is contributing a substantial share in household income in small scale farm PU-3 by 40 percent while the medium and large scale typical farms PU-6 and PU-9 have 17 and 16 percent share respectively in household income. The share of crop enterprise for PU-9 and PU-6 is 71 and 59 percent respectively while the share for PU-3 is 19 percent in the household income. 
The share of off-farm income for PU-3, PU-6 and PU-9 is 27, 12 and 6 percent respectively in the household income. The share of other farm income for PU-3, PU-6 and PU-9 is 13,13 and 7 percent respectively in the household income.

Four improvement intervention scenarios are evaluated to measure the impact on the household income by using the partial budgeting technique. One typical farm PU-3 that represents 56 percent of the surveyed population is selected to evaluate the improvement scenarios. The farm faces issues of low productivity and produces an income of US\$ 0.83 per capita per day which is below the international poverty line of US \$ 1 per capita per day to maintain minimum living standard. The improvement is compared after ex-ante simulation with the baseline farm PU-3. The increase in milk production and higher returns from dairy is transformed into household income presented as per capita income per day.

The selected improvement scenarios are fodder improvement, husbandry and health improvement, breeding improvement, and marketing improvement. The analysis shows that the impact of breed improvement is the highest for increasing the household income. The per capita income is improved from US\$ 0.83 to US\$ 1.18 and US\$ 1.02 per capita per day for breed improvement and animal husbandry and health improvement interventions respectively. The breed improvement scenario showed highest increased in per capita income by 38 percent while the other three scenarios of husbandry \& health, fodder and marketing interventions showed an increase in per capita income by 21,7 and 2 percent respectively. 


\section{Literature Index}

ADAMS R (1986): Development and social change in rural Egypt. Syracuse, N.Y, USA, Syracuse University press

ADAMS RH, HE JJ (1995): Sources of income inequality and poverty in rural Pakistan. Research Report, Vol. 102, International Food Policy Research Institute, Washington D.C. USA

AGRICULTURAL CENSUS ORGANIZATION, Government of Pakistan, Statistics Division, Lahore, Pakistan (1998c): Livestock Census 1996, Pakistan. Vol. 1

AHMAD M, MALIK SZ (1997): Genetic improvement of Cattle, Buffalo and Small Ruminants in Pakistan; Requirements and Past Experience. In: A. S. Abeyratne (Ed.) Breeding programmes for ruminants on Asia, concepts, facts, recommendations. pp. 109-134. Ministry of Livestock Development, Department of Animal Production and Health \& GTZ, Peradeniya, Sri Lanka \& Eschborn, Germany

AHMAD M, SAJI MA (1997): Buffalo and Cattle Development in Punjab. Livestock \& Dairy Development Department, Government of Punjab; GTZ, Lahore, Pakistan

AHMAD M, ATTYIA B et al. (2000): Punjab Livestock Census, Department of livestock and Dairy Development

AKHTAR M, BYERLEE D, KHALEEL T (1992): Developing Appropriate Cropping Patterns for the Cotton-wheat System of the Southern Punjab: Plant Breeding and Policy Perspectives. In: Farming Systems of Pakistan, pp. 31-61. Editors: BYERLEE D, HUSSAIN T Vanguard Books Pvt. Ltd., Islamabad

ALDENDERFER MF, BLASHFIELD RK (1984): Cluster Analysis. University Paper series on Quantitative Application in the Social Sciences, 07-044, Beverly Hills, CA: Sage

ALDERMAN H, GARCIA M (1993): Poverty, farm households food security, and nutrition in rural Pakistan. Research Report, Vol. 96, International Food Policy Research Institute, Washington D. C., USA

ALFF C (1997): Die Lebens- und Arbeitsbedingungen von Frauen im ländlichen Punjab/Pakistan. Abhandlungen - Anthropogeographie, Institut für geographische Wissenschaften, Freie Universität, Berlin, Vol. 56, Dietrich Reimer Verlag, Berlin, Germany

ANJUM MS, LODHI K, RAZA AA, WALTERS F, KRAUSE S (1989): Pakistan's dairy industry -issues policies and alternatives. Vol. Special Report No. 14, Economic Analysis Project Network with Ministry of Food, Agriculture and Cooperatives, Government of Pakistan and United States Agency for International Development, Islamabad, Pakistan 
ANNOYMAOU (2002): Milk Development Strategy Report, Small and Medium Enterprise development Authority (SMEDA), Lahore, Pakistan

BEBE BO, UDO HMJ, THORPE W (2003c): Development of smallholder dairy systems in the Kenya highlands. Outlook on Agriculture 31: 113-120

BHATTI JA, AHMAD Z, HANJRA SH, KHAN MA, GILL RA (1989): Prospects and limitations of livestock production on small farms. Pakistan Journal of Agricultural Sciences 26: 1-7

BOCKSTAEL, NANCY E (1996): Modeling Economics and Ecology: The Importance of a Spatial Perspective, American Journal of Agricultural Economics78 (5): 1168-1180. CARY J W, HOLMES W E (1982): Relationship among Farmers’ Goals and Farm Adjustment Strategies: Some Empirics of a Multidimensional Approach, Australian J. Agri. Econ., 26: 114-130

BOEHLJE MD, EIDMAN VR.1984: Farm management. John Wiley and Sons, New York, USA

BURKI AA, KHAN MA, BARI F (2005): The State of Pakistan's Dairy Sector: An Assessment. CMER Working Paper Series, Vol. 05-34, Lahore University of Management Sciences, Lahore, Pakistan

CENSUS ORGANIZATION OF PAKISTAN (2000) Agriculture Census Report

CENSUS ORGANIZATION OF PAKISTAN (2003) Agriculture Census Report

CHAUDHRY MA, SALEEM NA, ASGHAR AA, CHAUDHRY MS (1988b): Differences in productive and reproductive performances of Nili-Ravi buffalo heifers due to altered plane of nutrition. Indian Journal of Animal Nutrition 5: 87-93

CHEEMA MS, AHMAD B, CHAUDHRY MA, WAHLA MA (1992): Baseline socioeconomic survey of selected model villages in rural development project (Faisalabad - Pakistan).Department of farm management, university of agriculture, Faisalabad, Pakistan

CROWDER LV (1988): Fodder crops resources; a report on a review in Pakistan. ADB mission report, pp. 15

DALSTED NL (1992): Colorado State University Cooperative Extension economist/farm management and professor, and P. H. Gutierrez, former Extension economist/farm management and associate professor; agricultural and resource economics. Reviewed 10/04

DARNHOFER I, GRETZMACHER R, SCHNEEBERGER W (1997): Modelling farmers' decisions: a comparison between HDM and CART for oats-vetch adoption in the Ethiopian Highlands. Bodenkultur 48: 271-280

DEBLITZ C, HEMME T, ISERMEYER F et al. (1998): Executive Summary A Framework For Developing International Representative Dairy Farms: A Case Of Dairy AFPC Working Paper 98-9 
DELGADO CL, ROSENGRANTMW, MEYER S (2001): Livestock to 2020: The revolution continues. Paper presented to the International Agricultural Trade Research Consortium, Auckland, New Zealand, January 2001

DOST M, Fodder Oats in Pakistan (1997): Publication by Agha Khan Rural Support Program (AKRSP), Gilgit, Pakistan

DOST M (2002): Fodder production for Peri-Urban Dairies in Pakistan. FAO - Agriculture: Crop \& Grassland Service, Rome, Italy

DOST M, HUSSAIN A, KHAN S, BHATTI MB (1994). Green forage yield, dry matter yield, and chemical composition of oat with advances in maturity. Pak. J. Sci. Ind. Res., vol 37, no. 5:198-200

EHUI S, REY B (2001) Partial budget analysis for on-station and on-farm small ruminant production systems research: Method and data requirements International Livestock Centre for Africa,PO Box 5689, Addis Ababa, Ethiopia

FAO (1987): Pakistan's experience in rangeland rehabilitation and improvement. Food and Agriculture Organization of the United Nations. 70 pp

FEAGIN J, ORUM A, SJOBERG G (Eds.) (1991): A case for case study. Chapel Hill, NC: University of North Carolina Press

FEDERAL BUREAU OF STATISTICS, GOVERNMENT OF PAKISTAN (2000): Pakistan Population Censuses

FISCHER KM (2000): Idara-e-Kissan - A viable and self-financing development approach for poverty alleviation in the Punjab Province of Pakistan. Livestock \& Dairy Development Department, Government of Punjab, Lahore, Pakistan

FOOD AND AGRICULTURE ORGANIZATION (2002): FAO Production Year Book. 2002, Rome, Italy. http://www.fao.org.

FOOD AND AGRICULTURE ORGANIZATION (2003): FAO Production Year Book. 2003, Rome, Italy. http://www.fao.org.

FOOD AND AGRICULTURE ORGANIZATION (2004): FAO Production Year Book. 2004, Rome, Italy. http://www.fao.org.

FOOD AND AGRICULTURE ORGANIZATION (2005): FAO Production Year Book. 2005, Rome, Italy. http://www.fao.org.

FOOD AND AGRICULTURE ORGANIZATION (2006): FAO Production Year Book. 2006, Rome, Italy. http://www.fao.org.

FOOD AND AGRICULTURE ORGANIZATION and ASIAN DEVELOPMENT BANK (1987): Pakistan Livestock Sector Study, Investment centre no 55/87 AS-PAK 39. Volume 1 and II 
GARCIA O, MAHMOOD K, HEMME T (2003): A Review of Milk Production in Pakistan with Particular Emphasis on Small-Scale Producers, FAO policy paper Rome, Italy

GARCIA O, SAHA K, MAHMOOD K, HEMME T (2006): Dairy Development Activities in Andhra Pradesh, India: Impacts and risk analysis on small scale dairy farms, FAO policy paper Rome, Italy

GRANDSTAFF SW, GRANDSTAFF TB, LOVELACE GW (1987): Summary Report. Proceedings of the 1985 International Conference on Rapid Rural Appraisal. Khon Kaen, Thailand: Khon Kaen University, 1987: 3-30

HAIDER AS (1997): Farmers' requirements and assessment of Livestock and Dairy Development Department (L\&DDD) services - Government of Punjab. P\&E, L\&DDD, Lahore, Pakistan

HAMMERSLEY M (1995): The Politics of Social Research. London: Sage

HARRIS D (2006): Report on Dairy Mission to Pakistan undertaken for Australian Centre for International Agriculture Research

HASHIM, M.A. (1995): Situation and Potentials of Improving Smallholder Farming Systems in Semi-Arid Areas in Western Sudan. Farming Systems and Resource Economics in the Tropics, Vol.21, Wissenschaftsverlag Vauk, Kiel, Germany

HASNAIN HU, USMANI RH (2006): Livestock of Pakistan. Livestock Foundation Islamabad

HASSAN A, UL-HAQ M (1995): Farm accounts, family budgets of rural families and cost of production of major crops in Punjab: 1992-93. Vol. 303, Punjab Economic Research Institute, Lahore, Pakistan

HIRASHIMA, SHIGEMOCHI (1978): The Structure of the Disparity in Developing Agriculture: A Case Study of the Pakistan Punjab. Tokoyo: Institute of Development Economics

HUGHES KA, HASLEMORE RM (1984): Autumn sown cereals: yield and nutritive value of a range of winter forages in the Manawatu. N.Z.J. Exp. Agric. 12:1-5

HUSSAIN A, DOST M, KHAN S, BHATTI MB (1993): Forage yield and quality potential of various cultivars of oats (Avena sativa). Pak. J. Sci. Ind. Res., vol.36, nos. 6-7

HUSSAIN A, KHAN S, MOHAMMAD D, BHATTI MB (1994): Economic returns of oat (Avena sativa) under various cutting intervals. Indian Journal of Agricultural Sciences 64: 619-23

INTERNATIONAL CENTER FOR RESEARCH ON DRY AREA (ICARDA) and NATIONAL AGRICULTURE RESEARCH SYSTEM (NARS) (2005): Community Action in Integrated and Market Oriented Feed-Livestock Production in Central and South Asia Project 
IQBAL M et al. (2000): Agrarian Economies of the Two Punjab’s

IRFAN M (1990): Milk production by small farmers in Punjab. Peasant Commission, Government of Punjab, Lahore, Pakistan

ISERMEYER F (1987): Produktionsstrukturen, Produktionskosten und Wettbewerbstellung der Milcherzeugung in Nordamerika, Neuseeland und der EG. Dissertation an der Georg-August-Universität Göttingen. Wissenschaftsverlag Vauk, Kiel, 1987

JAFRI, YOUNUS SM (1999): Assessing Poverty in Pakistan. In: A profile of poverty in Pakistan. pp. 7-44. Mahbub ul Haq Centre for Human Development, Islamabad, Pakistan

JAMEEL M (1998): Impact Assessment Of Livestock Development Project-Punjab, Punjab Economic Research Institute

JOST N (1979): Animal health and reproduction - Livestock production and marketing survey, Punjab - Report No. 2. Livestock Development Centre, Bahadurnagar; Livestock Production Extension and Artificial Insemination Service, Lahore; GTZ, Eschborn, Lahore, Pakistan; Eschborn, Germany

JOST N (1980): Production and sales of milk and ghee - Livestock production and marketing survey, Punjab - Report No. 5. Livestock Development Centre, Bahadurnagar; Livestock Production Extension and Artificial Insemination Service, Lahore; GTZ, Eschborn, Lahore, Pakistan; Eschborn, Germany

JOST N (1984a): Economics of Buffalo Milk Production in the Punjab/Pakistan, Report No. 13 - Part 1: Survey results (milk production). Vol. 1, GTZ, Eschborn, Germany

JOST N (1984b): Economics of Buffalo Milk Production in the Punjab/Pakistan, Report No. 13 - Part 1: Survey results (milk production) - Annexes. Vol. 1-Annexes, GTZ, Eschborn, Germany

JOST N (1984c): Economics of Buffalo Milk Production in the Punjab/Pakistan, Report No. 13 - Part 2: Data framework for farm planning. Vol. 2, GTZ, Eschborn, Germany

JOST N (1986a): Economics of Buffalo Milk Production in the Punjab/Pakistan, Report No. 13 - Part 3: Farm analysis. Vol. 3, GTZ, Eschborn, Germany

JOST N (1986b): Economics of Buffalo Milk Production in the Punjab/Pakistan, Report No. 13 - Part 4: Summary. Vol. 4, GTZ, Eschborn, Germany

KHAN F et al. (2000): Agrarian Economies of the Two Punjab’s

KHAN MA (1998): PhD thesis, Farmer's Objectives and Adjustment of New Crops in the Irrigated Farming Systems of Pakistan's Punjab, University of Reading 
KHAN MA (1998b): Farmers' objectives and the choice of new crops in the irrigated farming systems of Pakistan's Punjab. PhD thesis, Department of Agriculture, University of Reading

KUROSAKI T (1998) Risk and Farm households Behaviour in Pakistan’s agriculture, Institute of Development Economics, Tokyo

KUROSAKI T (1996): Milk, Fodder, and the Green Revolution: The Case of Mixed Farming in the Pakistan Punjab. Pakistan Development Review. 35(4) Part II, Winter 1996: 537-548

KUROSAKI T (2007): Production Risk and Advantages of Mixed Farming in the Pakistan Punjab. Developing Economies. 35(1), March 1997: 28-47.

LANDAIS E (1998): Modelling farm diversity new approaches to typology building in France. Agricultural Systems 58: 505-527

LEVY S (1988). Information technologies in universities: An institutional case study. Un published doctoral dissertation, Northern Arizona University, Flagstaff

MAHMOOD K, ALEJANDRO N, PRATT, MOHAMMAD JA (2005): Comparison of Dairy Policies and Development in South Asia and East Africa, International Livestock Research Institute, Kenya

MCCONNEL DJ, DILLON JL (1997): Farm management for Asia: a systems approach. FAO Farm Systems Management Series, Vol. 13, FAO, Rome, Italy

MINFAL (Ministry of Food, Agriculture and Livestock) (1995): Agricultural Statistics of Pakistan 1994-95. MINIFAL, Government of Pakistan, Islamabad

MINISTRY OF ECONOMIC AFFAIRS, GOVERNMENT OF PAKISTAN (2002): Economic survey of Pakistan (2001-02)

MINISTRY OF ECONOMIC AFFAIRS, GOVERNMENT OF PAKISTAN (2003): Economic survey of Pakistan (2002-03)

MINISTRY OF ECONOMIC AFFAIRS, GOVERNMENT OF PAKISTAN (2004): Economic survey of Pakistan (2003-04)

MINISTRY OF ECONOMIC AFFAIRS, GOVERNMENT OF PAKISTAN (2005): Economic survey of Pakistan (2005-06)

MINISTRY OF FOOD, AGRICULTURE AND LIVESTOCK, GOVERNMENT OF PAKISTAN (2001): Agriculture statistics of Pakistan 2000-01

MINISTRY OF FOOD, AGRICULTURE AND LIVESTOCK, GOVERNMENT OF PAKISTAN (2002): Agriculture statistics of Pakistan 2001-02

MINISTRY OF FOOD, AGRICULTURE AND LIVESTOCK, GOVERNMENT OF PAKISTAN (2003): Agriculture statistics of Pakistan 2002-03

MINISTRY OF FOOD, AGRICULTURE AND LIVESTOCK, GOVERNMENT OF PAKISTAN (2004): Agriculture statistics of Pakistan 2003-04 
MINISTRY OF FOOD, AGRICULTURE AND LIVESTOCK, GOVERNMENT OF PAKISTAN (2005): Agriculture statistics of Pakistan 2004-05

MINISTRY OF FOOD, AGRICULTURE AND LIVESTOCK, GOVERNMENT OF PAKISTAN (2006): Agriculture statistics of Pakistan 2005-06

MOJENA R (1977): Hierarchical Grouping Methods and Stopping Rules: An Evakuation. The Computer Journal; 20: 359-363.

MUTSAERS HJW, FISHER NM, VOGEL WO, PALADA MC (1986): Farming systems program: A field guide for on-farm research with special reference to improvement of cropping systems and technologies in West and central Africa. International Institute of Tropical Agriculture, Ibadan, Nigeria. 197 pp

NIAZ MS (1997): Prime Minister Package of agriculture reforms. Agro Veterinary News

NORMAN DW, WORMAN FD, SIEBERT JD, MODIAKGOTLA E (1995): The farming systems approach to development and appropriate technology generation. FAO Farm Systems Management Series, Vol. 10, FAO, Rome

OUMA EA, OBARE GA, STAAL SJ (2004): The socio-economic dimensions of smallholder livestock management in Kenya and its effects on competitiveness of crop-livestock systems. Uganda Journal of Agricultural Sciences 9: 37

PAKISTAN AGRICULTURAL RESEARCH COUNCIL (1987): Agro-ecological Regions of Pakistan. PARC, Islamabad

PAKISTAN CENSUS ORGANIZATION (2004): PAKISTAN CENSUS Report

PAKISTAN METROLOGICAL DEPARTMENT (2004): Pakistan weather report

PARIS Q (1991): An economic interpretation of linear programming. Iowa State University Press,Ames, Iowa, USA

PLANNING \& EVALUATION DIRECTORATE, PUNJAB LIVESTOCK and DAIRY DEVELOPMENT DEPARTMENT (1998): Cattle and Buffalo development Punjab'. Pakistan -German Technical Co-operation

POATE CD, DAPLYN PF (1993): Data for agrarian development. Wye studies in agricultural and rural development, Cambridge University Press, Cambridge

PYECHA J (1988): A case study of the application of non categorical special education in two states. Chapel Hill, NC: Research Triangle Institute

QURESHI SK (1995): Credit for Rural Poor in Pakistan. The Pakistan Development Review 34: 769-778

RAYMOND WF (1969): The nutritive value of forage crops. Advan Agron. 21:1-108

RICHARD H, ADAMS JR (1996): Livestock income, male /female animals, and inequality in Rural Pakistan, Discussion paper no 21, Food consumption and nutrition Division, International Food Policy Research Institute (IFPRI), USA 
ROGER, NORTEN D (2002): Agriculture development Policy, Concepts and experiences part 1 and part 11. Draft. TCAS working documents 43/1 and 43/2 FAO Rome

ROSEGRANT et al. (1995): IFPRI, Food, Agriculture and Environment Discussion paper 3

SAHA AK (2003): Dissertation on Economic evaluation of dairy systems in Haryana. National Dairy Research Institute (deemed University of Karanal)

SARWAR M, SALEEM MA (1993a): Baseline Study of Punjab Small Holders Dairy Development Project - Gujranwala; Gujranwala and Gujrat Districts. Punjab Economic Research Institute, Lahore, Pakistan

SARWAR M, SALEEM MA (1993b): Baseline Study of Punjab Small Holders Dairy Development Project - Gujranwala; Sialkot and Narowal Districts. Punjab Economic Research Institute, Lahore, Pakistan

SARWAR M, KHAN MA, Mahr-un-Nisa, IQBA Z (2002): Review of dairy industry in Pakistan: a scenario. International Journal of Agriculture and Biology 4(3) 420-428

SCHINZEL HU (1979a): Demand, supply and marketing of livestock products, Report No. 9. GTZ, Eschborn, Germany

SCHINZEL HU (1979b): Systems and channels of milk marketing, Report No. 1. GTZ, Eschborn, Germany

SHARMA AK, MEHTA P (1990): Optimum combination of milch cattle and crops in sub mountainous low hills subtropical zone of Himachal Pradesh. Indian Journal of Dairy Science 43: 302-307

SHEIKH BA, SHEIKH SA et al. (2005): Pakistan Agriculture in global perspectives, Pakistan Journal of Agriculture, Agriculture Engineering and veterinary Sciences 21(2) 53-59

SHRESTHA RL, EVANS DB (1984): The private profitability of livestock in a Nepalese hill farming community. Agricultural Administration 16 (March):145-158

SINGH I (1990): The great ascent, the rural poor in south Asia. Baltimore, Md. USA: Johns Hopkins University press

SOLANO C, BERNUES A, ROJAS F, JOAQUIN N, FERNANDEZ W, HERRERO M (2000): Relationships between management intensity and structural and social variables in dairy and dual-purpose systems in Santa Cruz, Bolivia. Agricultural Systems 65: 159-177

STAAL S, MULLINS G (1996): Dairy consumption and its determinants in Coastal Kenya. KARI/ILRI collaborative research report. ILRI, Nairobi, Kenya

STAKE R (1995): The art of case research. Newbury Park, CA: Sage Publications

STATE BANK OF PAKISTAN (2003): Annual report 2002-2003

SWOG Report (2004): The white Revolution, Strategic plan for Pakistan Dairy Industry 
TEUFEL N (1995): Untersuchung zur kleinbäuerlichen Ziegenhaltung im Punjab (Pakistan). Diplomarbeit, Institut für Tierproduktion in den Tropen und Subtropen, Universität Hohenheim

TEUFEL N (2006): PhD Thesis "Smallholder milk production in the Punjab of Pakistan and the evaluation of potential interventions", Institute of Animal Production in the Tropics and Subtropics Section Animal Breeding and Husbandry University of Hohenheim

UDO HMJ, BROUWER BO (1993): A computerised method for systematically analysing the livestock component of farming systems. Computers and Electronics in Agriculture 9: 335-356

UDRY C (1996): Gender, Agricultural Production, and the Theory of the Farm households. Journal of Political Economy, 104: 1010-46, 1996

UPTON M (1996): The economics of tropical farming systems. Wye Studies in Agricultural and Rural Development, Cambridge University Press, Cambridge, UK

UPTON M, DIXON JM (1994): Methods of micro-level analysis for agricultural programmes and policies - A guideline for policy analysts. FAO Farm Systems Management Series, Vol. 9, FAO, Rome, Italy

UZ-ZAMAN K, ASHRAF M, SALEEM MA (1998a): Evaluation of Punjab small holders dairy development project, Gujranwala. Vol. 331, Punjab Economic Research Institute, Lahore, Pakistan

WILLIAMS TO (1994): Identifying target groups for livestock improvement research: the classification of sedentary livestock producers in Western Niger. Agricultural Systems 46: 227- 237

WINTERS P, HARDAKER B, PATRICK I (2002): Defining Practical Guidelines for Evaluating Long-term, Smallholder Decision-making in Developing Countries. Impact Assessment Program, Working Paper Series, Vol. 44, Australian Centre for International Agricultural Research (ACIAR), Canberra, Australia

WORMAN F, NORMAN O, WARE-SNYDER J (eds.) 1990: Agricultural technology improvement project. Farming Systems Research Handbook for Botswana ATIP RP3. Department of Agricultural Research, Ministry of Agriculture, Botswana

WYNN P et al. (2006): Report on Dairy Mission to Pakistan undertaken for Australian Centre for International Agriculture Research

YADAV BL, YADAV MC (1998): Adoption of buffalo husbandry practices by farmers of different sizes of land holding in the home tract of Murrah. International Journal of tropical agriculture, 15(124), 277-281

YIN R (1989a): Case study research: Design and methods (Rev. ed.). Beverly Hills, CA: Sage Publishing

YIN R (1993): Applications of case study research. Beverly Hills, CA: Sage Publishing 
YIN R (1994): Case study research: Design and methods (2nd ed.). Beverly Hills, CA: Sage Publishing

YOUNAS M, YAQOOB M (2004): Report on Rural Livestock Production in Pakistan, Faculty of Animal Husbandry, University of Agriculture. Faisalabad

YUCER O, MAKTAV S, XU S, TAFT DICK J, UTKAN H, FRAHI B, LOKOLLO J, JAMA M, KASAJU P, ABOUL-NAGA AM, GUMEN R, FALT E (2000): United Nations Statement on Food Security in Pakistan. United Nations System in Pakistan, Islamabad, Pakistan

ZAFAR AH (1985): Economics of rural dairy animals in canal irrigated area of the Punjab.Livestock Production Research Institute, Bahadurnagar, Okara, Pakistan

ZEPEDA L, BUELOW KL, NORDLUND KV, THOMAS CB, COLLINS MT, GOODGER WJ (2000): A linear programming assessment of the profit from strategies to reduce the prevalence of Staphylococcus aureus mastitis. Preventive Veterinary Medicine 44: 61-71 


\section{Annex}


Annex 1: $\quad$ Map of Pakistan

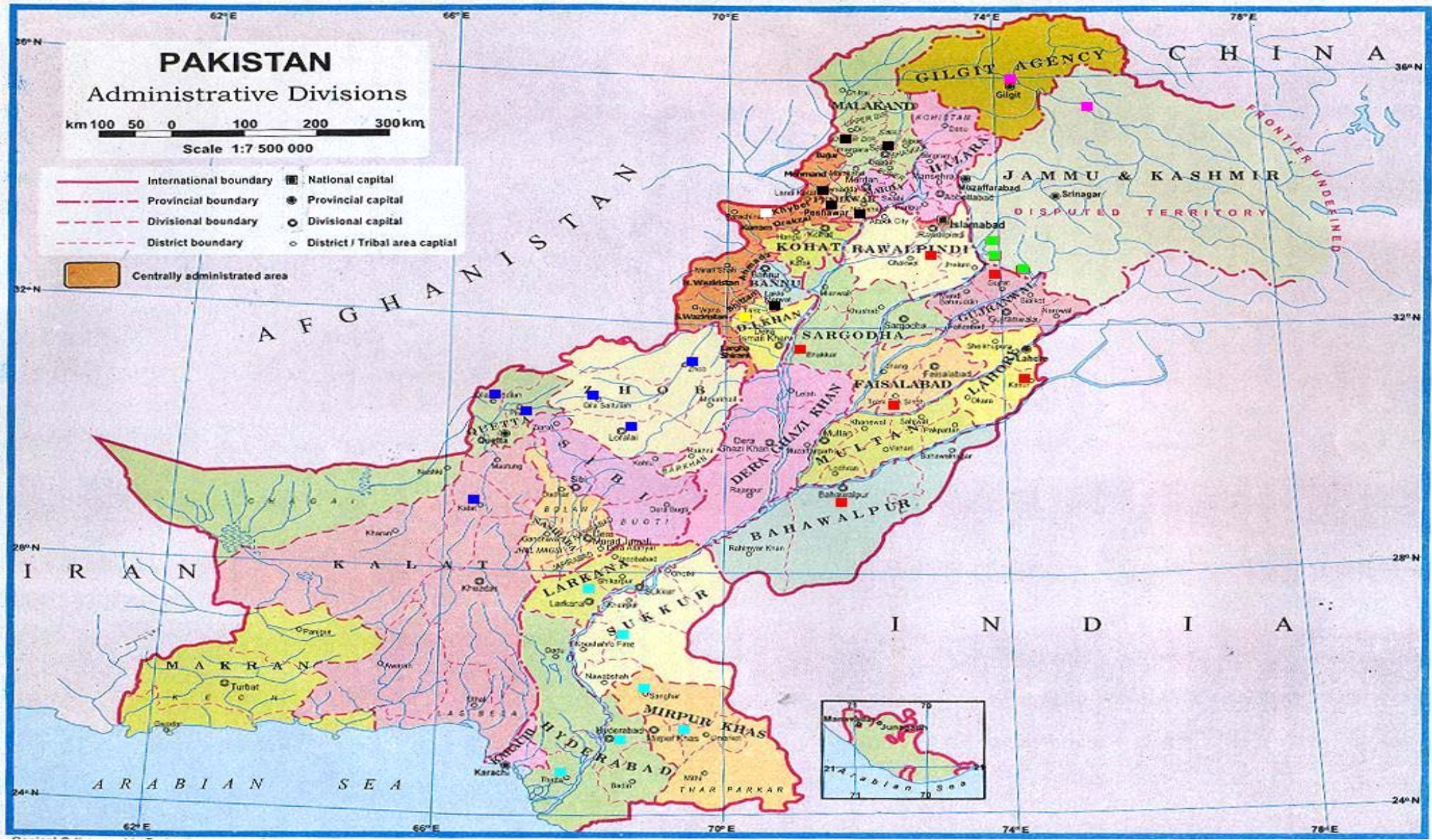


Annex 2:

Pakistan Agro Ecological zones with major crops, fodder and fruit trees

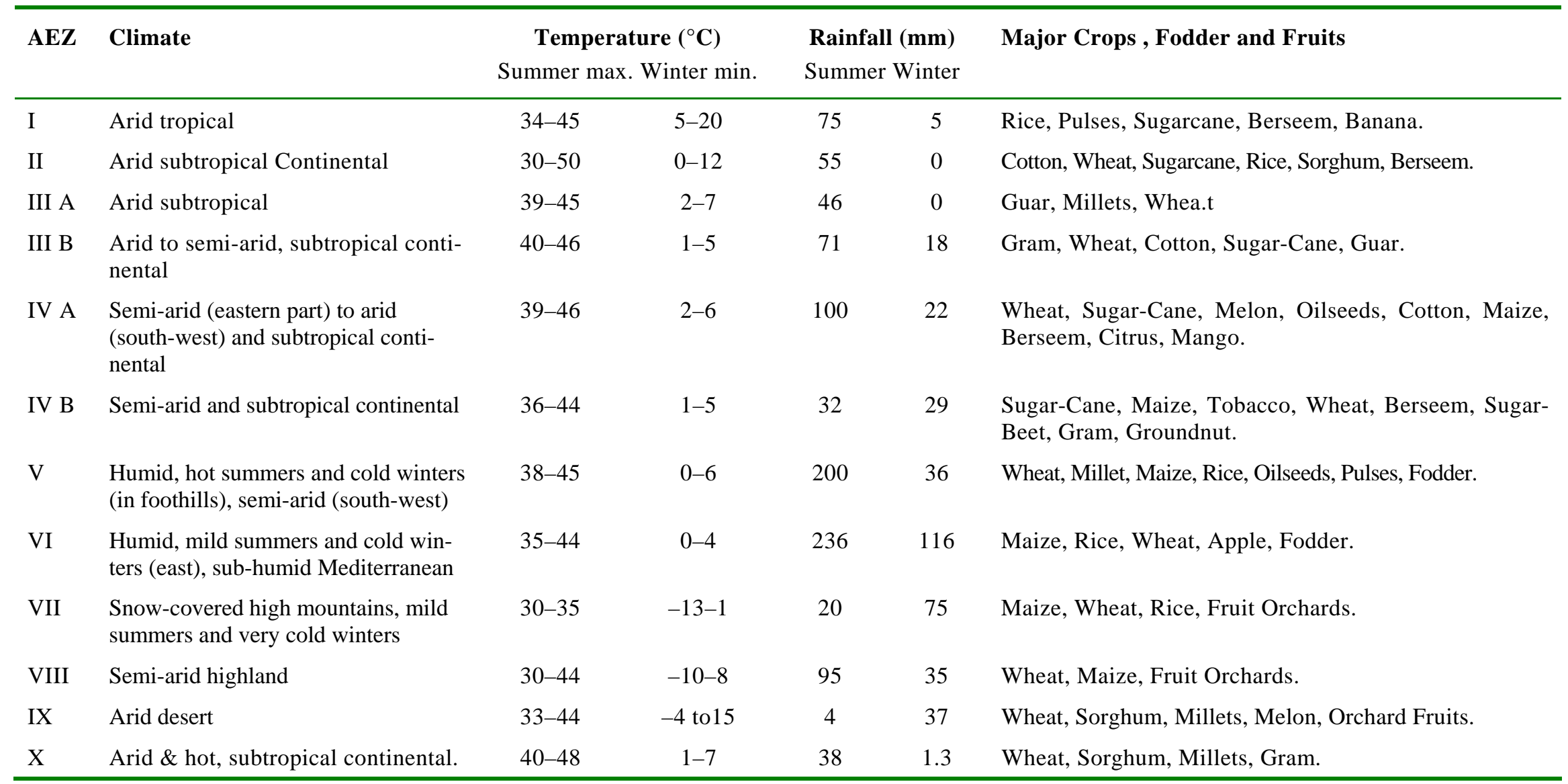

Description of numbers I=Indus Delta; II=Southern irrigated plain; III-A=Sandy desert, III-B=Sandy desert; IV-A=Northern irrigated plains; IV-B=Northern irrigated plain; V=Barani (rain fed) areas, VI=Wet mountains; VII=Northern dry mountains; VIII=Western dry mountains; IX=Dry western plateau; X=Suleiman Piedmont.

Source : PARC (Pakistan Agricultural Research Council). 1980. Agro-ecological Regions of Pakistan. PARC, Islamabad. 
Annex 3: Landholding structure in Pakistan

\begin{tabular}{|c|c|c|c|c|c|}
\hline \multirow[t]{2}{*}{ Farm Size } & \multirow{2}{*}{$\begin{array}{c}\text { No of Farms } \\
\text { Nos }\end{array}$} & \multicolumn{2}{|c|}{ Farm Area } & \multicolumn{2}{|c|}{ Avg. Farm size } \\
\hline & & percent & ha. & percent & ha \\
\hline Private Farms & $5,070,963$ & & $19,149,673$ & & 3.78 \\
\hline Government Farms & 149 & & 103,035 & & \\
\hline All Farms & 507,112 & 100 & $19,252,672$ & 100 & - \\
\hline Under 0.5 & 678,538 & $13.4 \%$ & 193,126 & 1 & 0.3 \\
\hline $0.5-<1.0$ & 689,233 & $13.6 \%$ & 510,397 & 3 & 0.7 \\
\hline $1-<2$ & $1,036,286$ & $20.4 \%$ & $1,446,796$ & 8 & 1.4 \\
\hline $2-<3$ & 841,295 & $16.6 \%$ & $1,973,800$ & 10 & 2.3 \\
\hline $3-<5$ & 857,387 & $16.9 \%$ & $3,309,432$ & 17 & 3.9 \\
\hline $5-<10$ & 623,110 & $12.3 \%$ & $4,134,346$ & 22 & 6.6 \\
\hline $10-<20$ & 237,929 & $4.7 \%$ & $3,032,872$ & 16 & 12.7 \\
\hline $20-<60$ & 91,831 & $1.8 \%$ & $2,613,767$ & 14 & 28.5 \\
\hline More than 60 & 15,354 & $0.3 \%$ & $1,935,101$ & 10 & 126 \\
\hline
\end{tabular}

Source: Agricultural Statistics of Pakistan 2003. 
Annex 4: $\quad$ Milk production of Pakistan from 1990 to 2005 (mill. tonnes)

\begin{tabular}{lcccc}
\hline & $\mathbf{1 9 9 0}$ & $\mathbf{1 9 9 5}$ & $\mathbf{2 0 0 0}$ & $\mathbf{2 0 0 5}$ \\
\hline Cows milk & 3,523 & 4,293 & 8,039 & 9,082 \\
Buffaloes milk & 10,662 & 13,984 & 16,91 & 19,7 \\
Total milk & 14,19 & 18,28 & 24,95 & 28,78 \\
5-year avg. growth rate & & $5.1 \%$ & $6.7 \%$ & $2.9 \%$ \\
\hline
\end{tabular}

Source: FAO STATISTICS, www.fao.org

Annex 5: $\quad$ Milking herd population of Pakistan 1990-2005

\begin{tabular}{lcccc}
\hline & $\mathbf{1 9 9 0}$ & $\mathbf{1 9 9 5}$ & $\mathbf{2 0 0 0}$ & $\mathbf{2 0 0 5}$ \\
\hline Milking cows (mill. head) & 7.07 & 8 & 10 & 11 \\
Milking Buffaloes (mill. head) & 9.9 & 11 & 13 & 15 \\
Total milking animals(mill. head) & 17 & 20 & 23 & 26 \\
5-year avg. growth rate & & $3.18 \%$ & $3.29 \%$ & $2.54 \%$ \\
\hline
\end{tabular}

Source: FAO STATISTICS, www.fao.org

Annex 6: $\quad$ Milk yield growth rate from 1990 to 2005

\begin{tabular}{lcccc}
\hline & $\mathbf{1 9 9 0}$ & $\mathbf{1 9 9 5}$ & $\mathbf{2 0 0 0}$ & $\mathbf{2 0 0 5}$ \\
\hline milk yield per cow (kg/lactation) & 498 & 572 & 794 & 816 \\
5-year growth rate & & $2.9 \%$ & $7.8 \%$ & $0.6 \%$ \\
milk yield per buffalo (kg/lactation) & 1,077 & 1,209 & 1,286 & 1,291 \\
5-year growth rate & & $2.5 \%$ & $1.3 \%$ & $0.1 \%$ \\
\hline
\end{tabular}

Source: FAO STATISTICS, www.fao.org 
Annex 7: $\quad$ Values of milk and various crops in Pakistan, 1997-2002

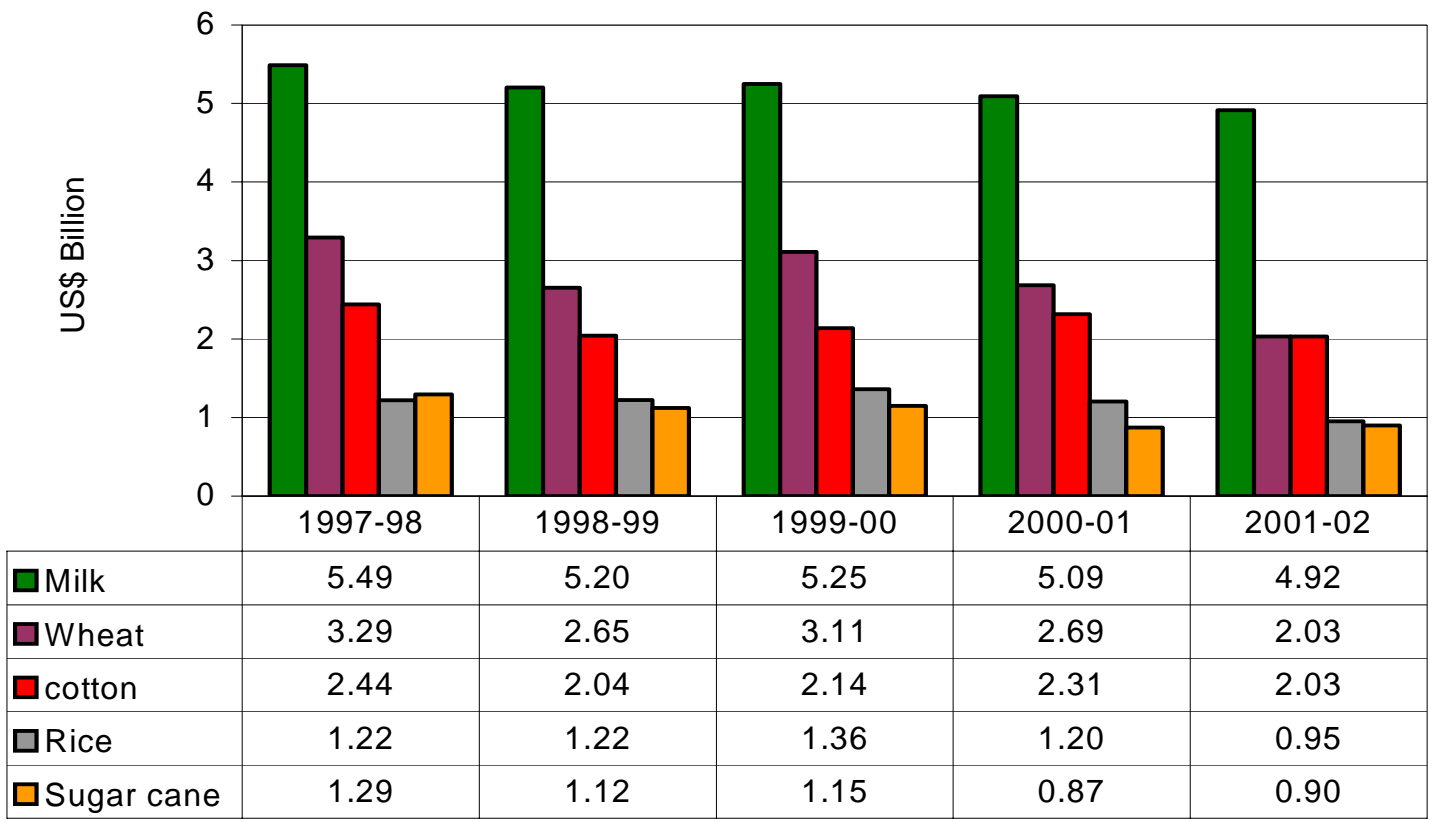

Source: Abstracted from Agriculture statistics of Pakistan 2002

Annex 8: $\quad$ Area under irrigation in Punjab

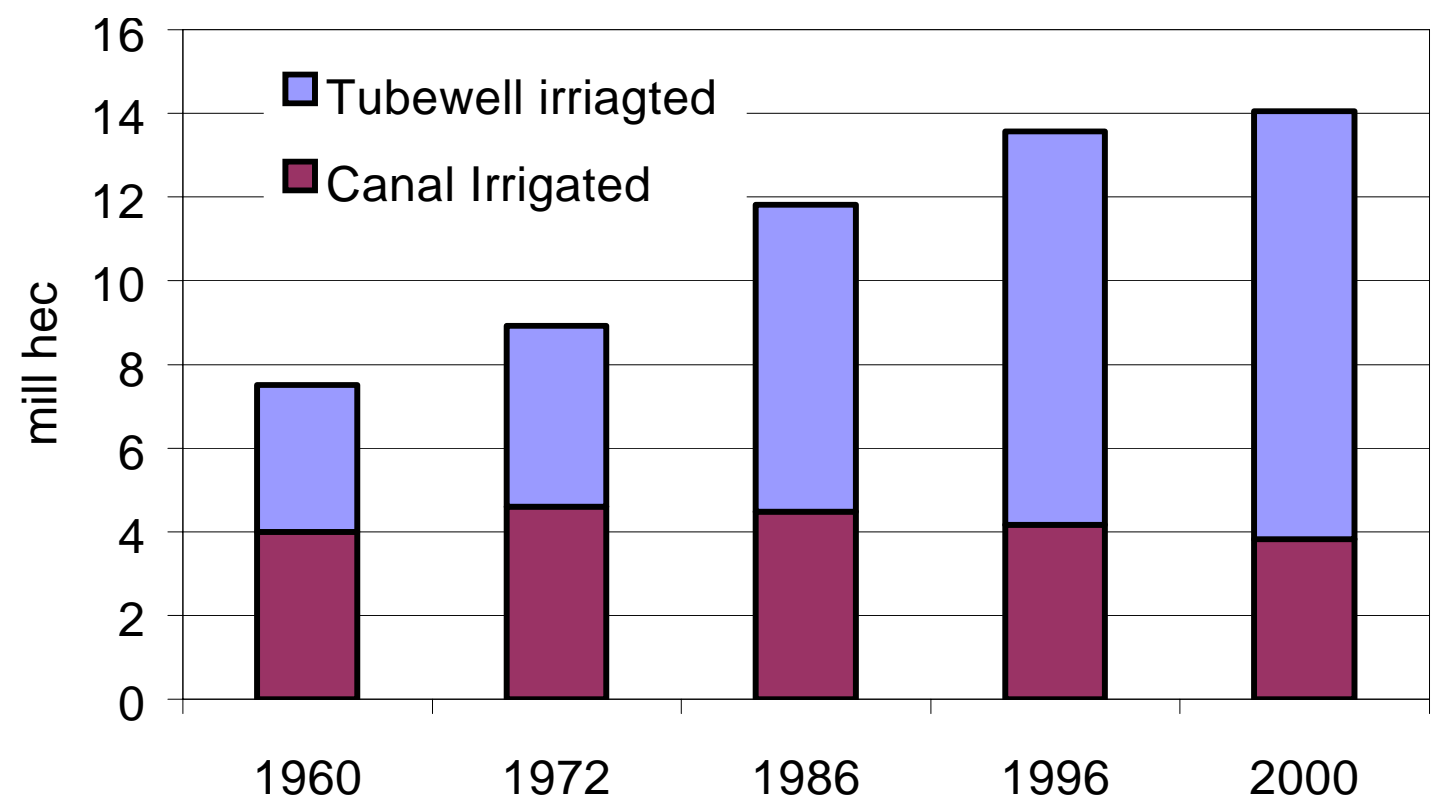


Annex 9: Monthly rainfall data of district Sargodha

\begin{tabular}{lllllllllllll}
\hline & Jan. & Feb. & Mar. & Apr. & May & Jun. & Jul. & Aug. & Sep. & Oct. & Nov. & Dec. \\
\hline 1998 & 7.5 & 60.1 & 12.1 & 66.5 & 29.9 & 24.6 & 98.1 & 133.1 & 0 & 0.3 & 0 & 0 \\
1999 & 57.5 & & 27 & 0 & 92.2 & 50.3 & 55.9 & 53 & 4.3 & 9 & 1.5 & 0 \\
2000 & 16.5 & 11 & 0 & 0 & 20 & 57.4 & 183.9 & 99 & 57.3 & 0 & 7 & 0 \\
2001 & 27 & 31 & 13 & 22 & 47 & 44 & 113 & 95 & 21 & 3 & 3 & 0 \\
\hline
\end{tabular}

Source: Pakistan Metrological department.

Annex 10: Livestock Population of district Sargodha - Rural (Punjab Census, 2000)

\begin{tabular}{|c|c|c|c|c|c|}
\hline Rural & Buffalo & Sahiwal cow & Crossbredcow & Cow Desi/other & Total cows \\
\hline Milk & 149,946 & 1,406 & 52,393 & 39,396 & 93,195 \\
\hline Dry & 113,502 & 892 & 23,767 & 19,796 & 44,455 \\
\hline 1-3 Heifer & 100,542 & 867 & 22,648 & 18,731 & 42,246 \\
\hline$<1$ Male & 60,394 & 614 & 21,736 & 18,912 & 41,262 \\
\hline$<1$ Fem & 66,732 & 687 & 23,489 & 18,524 & 42,700 \\
\hline 1-3 Male & 16,489 & 164 & 5,047 & 8,859 & 14,070 \\
\hline$>3$ Bull & 2,081 & 97 & 1,810 & 7,877 & 9,784 \\
\hline$>3$ Bullock & 332 & 42 & 4,824 & 50,310 & 55,176 \\
\hline Total & 510,018 & 4,769 & 155,714 & 182,405 & 342,888 \\
\hline
\end{tabular}

Source: Punjab Livestock Census, 2000. 
Annex 11: Livestock Population of District Sargodha - Urban

\begin{tabular}{lccccc}
\hline Urban & Buffalo & Sahiwal cow & Crossbred cow & Cow Desi/other & Total cows \\
\hline Milk & 8,710 & 136 & 4,008 & 1,060 & 5,204 \\
Dry & 4,714 & 52 & 1,377 & 522 & 1,951 \\
1-3 Heifer & 3,195 & 70 & 1,322 & 533 & 1,925 \\
$<$ 1 Male & 3,196 & 41 & 1,417 & 485 & 1,943 \\
$<$ 1 Female & 3,359 & 50 & 1,559 & 433 & 2,042 \\
1-3 Male & 290 & 9 & 197 & 113 & 319 \\
$>$ 3 Bull & 90 & 1 & 28 & 53 & 85 \\
$>$ 3 Bullock & 32 & 6 & 9,939 & 635 & 6,69 \\
Total & 23,586 & 365 & 3,834 & 141,38 \\
\hline
\end{tabular}


Annex 12: $\quad$ Seasonal variation of milk production (kg/day)

\begin{tabular}{|c|c|c|c|c|c|c|c|c|c|c|c|c|c|}
\hline & Jan & Feb & Mar & Apr & May & Jun & Jul & Aug & Sep & Oct & Nov & Dec & year \\
\hline Milk prod & 8.85 & 9.13 & 8.66 & 7.62 & 6.77 & 6.52 & 6.98 & 7.91 & 8.29 & 8.41 & 8.54 & 8.49 & 8.01 \\
\hline Milk sold & 1.98 & 1.91 & 1.40 & 0.84 & 0.73 & 1.02 & 1.39 & 1.94 & 2.25 & 2.10 & 2.00 & 1.92 & 1.62 \\
\hline Ghee sold44 & 0.46 & 0.31 & 0.26 & 0.35 & 0.46 & 0.44 & 0.41 & 0.34 & 0.24 & 0.27 & 0.28 & 0.39 & 0.35 \\
\hline Milk consumed & 1.91 & 2.02 & 2.00 & 1.82 & 1.82 & 1.82 & 1.89 & 1.94 & 1.85 & 1.84 & 1.88 & 1.90 & 1.89 \\
\hline ghee consumed & 4.50 & 4.90 & 5.01 & 4.61 & 3.77 & 3.25 & 3.31 & 3.69 & 3.97 & 4.21 & 4.89 & 4.78 & 4.16 \\
\hline milk purchased & 0.02 & 0.01 & 0.01 & 0.02 & 0.01 & 0.07 & 0.10 & 0.05 & 0.03 & 0.04 & 0.04 & 0.03 & 0.04 \\
\hline ghee purchased & 0.10 & 0.08 & 0.09 & 0.20 & 0.23 & 0.18 & 0.15 & 0.09 & 0.10 & 0.06 & 0.02 & 0.07 & 0.11 \\
\hline veg. oil consumed & 0.01 & 0.01 & 0.01 & 0.07 & 0.01 & 0.05 & 0.03 & 0.03 & 0.03 & 0.02 & 0.03 & 0.02 & 0.03 \\
\hline
\end{tabular}

Source: JOST (1984).

44 Butter oil, shown in M Eql. (milk equivalents, factor 18.8) 
Annex 13: Standardizing family members as Adult man equivalent

Adult man Equivalent

Adult Man (> 18)

Adult woman (> 18 )

0.92

Old age parents $(>65)$

0.8

Children (14-18 year)

Children (under 14 year)

0.25

Other family labour type 
Annex 14: Questionnaire Farm households data collection

Typology attributes of mixed farming system

Type 1 Type 2 Type...

1. Family size

2. $\quad$ Avg. land holding

3. Owned land

4. Rented land

5. Off-farm income

6. Herd size

7. Herd mix(cow, Buffalo)

8. Farm managers age

9. Experience

10. Education

11. Value of farm equipment

12. Family labour (hours)

13. Hired labour (hours)

14. Income from dairy (milk and meat)

15. Income from other livestock.

16. Percent area for cash crops

17. Percent area for fodder crops

18. Distance from milk collection centre $(\mathrm{km})$

19. Milk produced per day

20. Milk sale per day

21. Milk price(per kg) Buffalo

22. Milk price(per kg) cow 
Annex 15: Questionnaire II detailed information of the farm households/ farm parameters 1. Family Living Expenditure
Food expenses
C/year

Clothing and home utilities

Education

Health

Others

Total

2- Off-farm income a)- Labour income
Labour and non labour income
c/year

1. Work on neighbours field (husband)

2. Other

b) - Enterprise income

\begin{tabular}{lllll} 
& & Enterprise 1 & Enterprise 2 & Enterprise 3 \\
Name & txt & & \\
Production quantity & units/year & & \\
Price & c/unit & & \\
Other value of production & c/year & \\
Operating costs & c/year & \\
Depreciation of assets & c/year & \\
Fixed assets & c/year & \\
Operating assets & c/year & \\
Selling assets & c/year & \\
\hline
\end{tabular}

3-Other Farm-Income / Enterprises

\begin{tabular}{lcccc}
\hline & & Enterprise 1 & Enterprise 2 & Enterprise 3 \\
Name & txt & & \\
Production quantity & units/year & & \\
Output price & c/unit & & \\
Other value of production & c/year & \\
Operating costs & c/year & \\
Depreciation of assets & c/year & \\
Fixed assets & c/year & \\
Selling assets & c/year & \\
\hline
\end{tabular}




\section{4-Land Data}

Land owned ha

Arable land rented ha

Rent prices

C/ha

Market value arable land

C/ha

Market value pastureland

C/ha

\section{5-Labour Data}

Farm Hired labour

Total hours per year

h/year

Part-time farm labour input

h/year

Salary per year

C/year

Costs part-time employee

Family Labour working time

Adult Man (> 18)

no.

Total hours per year h/year

Adult women (> 18 )

Total hours per year h/year

Old age parents (> 65) no.

Total hours per year h/year

Children (under 14-18 year)

no.

Total hours per year h/year

Children (under 14 year)

no.

Total hours per year h/year

Other family labour type

no.

Total hours per year h/year

Opportunity labour price per category

Adult Man (> 18)

$\mathrm{C} / \mathrm{h}$

Adult women $(>18)$

$\mathrm{C} / \mathrm{h}$

Old age parents $(>65)$

$\mathrm{C} / \mathrm{h}$

Children (under 14-18 year)

$\mathrm{C} / \mathrm{h}$

Children (under 14 year)

$\mathrm{C} / \mathrm{h}$

Other family labour type

$\mathrm{C} / \mathrm{h}$

\section{6-Capital prices interest rates}

Medium term loans

Short term loans

Operating loans

Savings 


\section{7-Fixed Expenses of the farm households}

Fixed expenses per year
Land improvement
Maintenance machinery
Maintenance buildings
Contract labour
Diesel for irrigation
Electricity

\section{7-Machinery inputs}

Market value $\quad$ Expected life

Total value

Depreciation

\section{8-Building list}

\begin{tabular}{|c|c|c|}
\hline Machinery list & Market value & Expected life \\
\hline Total value & & \\
\hline Depreciation & & \\
\hline
\end{tabular}

\section{9-Crop Enterprise:}

\begin{tabular}{cccccc}
\hline & Crop mix & Yield & Home consumption & Sale Price & \\
Crops & ha & t/ha & t/year & c/t & Seed \\
\hline
\end{tabular}

10-Crop variable costs

\begin{tabular}{|c|c|c|c|c|c|c|c|c|c|}
\hline crop list & $\begin{array}{c}\text { Fertilizer } \\
\text { c/ha }\end{array}$ & $\begin{array}{c}\text { Herbicides } \\
\text { c/ha }\end{array}$ & $\begin{array}{c}\text { Pesticides } \\
\text { c/ha }\end{array}$ & $\begin{array}{c}\text { Irrigation } \\
\text { c/ha }\end{array}$ & $\begin{array}{c}\text { Contractor } \\
\text { c/ha }\end{array}$ & $\begin{array}{l}\text { fuel } \\
\text { c/ha }\end{array}$ & $\begin{array}{l}\text { other } \\
\text { c/ha }\end{array}$ & $\begin{array}{l}\text { other } \\
\text { c/ha }\end{array}$ & $\begin{array}{l}\text { other } \\
\text { c/ha }\end{array}$ \\
\hline
\end{tabular}


11-Dairy Enterprise

Description of dairy animals

Type 1 Type2

No. of animals

no.

Milk yield per animal per year

$\mathrm{kg} /$ cow/year

Fat content

$0,0 \mathrm{x}$

Protein content

$0,0 \mathrm{x}$

Milk Price per kg milk

$\mathrm{C} / \mathrm{kg}$

percent animals die

$0,0 \mathrm{x}$

Animal sold

no.

Animal purchased

no.

Price of cull animals

$\mathrm{C} / \mathrm{kg}$

Age at first calving

month

percent calves (0-x) die

$0,0 \mathrm{X}$

percent heifers die

$0,0 \mathrm{X}$

\section{Variable Expenses per cow}

Vet. \& medicine

C/cow

Breeding costs

C/cow

Milk supplies

C/cow

vaccination

C/cow

Electricity

C/cow

other

C/cow

Livestock prices

Bulls

Female dairy calve

C/head

Male dairy calve

C/head

Heifers prices

C/head

Lactation period

days

Dry period between lactations

days

No of lactations life time

days 


\section{2-Return from other dairy enterprise}

Cow dung used as fuel

Draught power

Manure

\section{3-Milk consumption}

Milk consumed by the family

Milk consumed in other farm enterprises

Milk sold per day t/year

t/year

$\mathrm{kg} /$ day

\section{4-Home grown feed}

Crop1

\section{5-Purchased feed}

$\mathrm{c} / \mathrm{t}$

Cottonseed

Mineral nutrients

salt 
Annex 16: Survey data of the farm households from two villages of Sargodha

\begin{tabular}{|c|c|c|c|c|c|c|c|c|}
\hline & & 1 & 2 & 3 & 4 & 5 & 6 & 7 \\
\hline & Name of farmer & Khalid & $\begin{array}{l}\text { Sulaman } \\
\text { Shah }\end{array}$ & $\begin{array}{l}\text { Mazhar Javed } \\
\text { khan }\end{array}$ & Muhammad Shair & Abdul Razzaq & M. Arshad & Nadeem \\
\hline & Name of village & $74 / \mathrm{SB}$ & $74 / \mathrm{SB}$ & $74 / \mathrm{SB}$ & $74 / \mathrm{SB}$ & $74 / \mathrm{SB}$ & $74 / \mathrm{SB}$ & $74 / \mathrm{SB}$ \\
\hline \multirow[t]{4}{*}{1} & Family size & 24 & 14 & 8 & 8 & 7 & 5 & 12 \\
\hline & Male & 5 & 6 & 2 & 4 & 2 & 1 & 3 \\
\hline & Female & 5 & 4 & 2 & 4 & 4 & 1 & 3 \\
\hline & Children & 14 & 4 & 4 & 0 & 1 & 3 & 6 \\
\hline 2 & Avg. landholding (acr) & 3 & 32 & 65 & 10 & 8 & 2.5 & 6 \\
\hline 3 & Owned land & 0 & 20 & 65 & 10 & 5 & 2,5 & 6 \\
\hline 4 & Rented land & 3 & 12 & & 0 & 3 & 0 & 0 \\
\hline 5 & Off-farm income & 60,000 & 0 & 120,000 & 50,000 & 14,000 & 0 & 50,000 \\
\hline 6 & Herd size & 7 & 19 & 8 & 10 & 10 & 18 & 11 \\
\hline \multirow[t]{5}{*}{7} & Buffalo & 2 & 7 & 5 & 3 & 4 & 6 & 4 \\
\hline & Cow & 1 & 3 & & 1 & 1 & 3 & 2 \\
\hline & Calves & 2 & 6 & 3 & 3 & 3 & 5 & 2 \\
\hline & Heifers & 2 & 3 & & 2 & 2 & 4 & 3 \\
\hline & Bull & & & & 1 & 0 & 0 & 0 \\
\hline 8 & Farm manager's age & 60 & 29 & 50 & 68 & 38 & 52 & 26 \\
\hline 9 & Experience & 20 & 1 & 40 & 6 & 28 & 40 & 6 \\
\hline
\end{tabular}




\begin{tabular}{|c|c|c|c|c|c|c|c|c|}
\hline 10 & Education & 0 & 10 & 14 & 10 & 5 & 0 & 8 \\
\hline 11 & $\begin{array}{l}\text { Value of farm equip- } \\
\text { ment }\end{array}$ & 11,000 & 650,000 & 700,000 & 10,000 & 8,000 & 9,000 & 10,000 \\
\hline 12 & Family labour (hours) & 7,625 & 1,220 & 1,830 & 4,880 & 4,880 & 3,050 & 4,880 \\
\hline 13 & Hired labour (hours) & 30 & 2,640 & 2,970 & 2,640 & 0 & 0 & 0 \\
\hline 14 & $\begin{array}{l}\text { Income from dairy } \\
\text { (milk and meat) }\end{array}$ & 0 & 0 & 12,000 & 0 & 0 & 29,200 & 24,000 \\
\hline 15 & $\begin{array}{l}\text { Income from other live- } \\
\text { stock (sheep, goat, etc.) }\end{array}$ & 0 & 0 & & 0 & 5,000 & 30,000 & 0 \\
\hline 16 & Area for cash crops & 1.8 & 27 & 61 & 8 & 6 & 1.5 & 4.5 \\
\hline 17 & Area for fodder crops & 1.2 & 5 & 4 & 2 & 3 & 2 & 1.5 \\
\hline 18 & Distance from road(km) & 1.5 & 2.5 & 3 & 2 & 0.5 & 0.15 & 2 \\
\hline 19 & $\begin{array}{l}\text { Distance from milk col- } \\
\text { lection center }(\mathrm{km})\end{array}$ & 3 & 3 & 3 & 3 & 3 & 3 & 3 \\
\hline 20 & Milk sale per day & 3 & & & 0 & 0 & 4 & 0 \\
\hline 21 & Milk produced per day & 10 & 20 & 10 & 22 & 4 & 9 & 5 \\
\hline 22 & $\begin{array}{l}\text { Milk price for Buffaloes } \\
\text { (Rs/kg) }\end{array}$ & 20 & & 16 & 20 & 20 & 20 & 20 \\
\hline 23 & $\begin{array}{l}\text { Milk price for cows } \\
\text { (Rs/kg) }\end{array}$ & 12 & & & 12 & 12 & 13 & 13 \\
\hline
\end{tabular}




\begin{tabular}{|c|c|c|c|c|c|c|c|c|}
\hline & & 8 & 9 & 10 & 11 & 12 & 13 & 14 \\
\hline & Name of farmer & $\begin{array}{l}\text { Mahr M. } \\
\text { Bashir }\end{array}$ & Mailk Javaid & Rahim din & Muhammad Jamil & $\begin{array}{c}\text { Muhammad } \\
\text { Ishaq }\end{array}$ & Islam Din & Bashir Ahmad \\
\hline \multirow[t]{4}{*}{1} & Family size & 28 & & 7 & 11 & 9 & & 6 \\
\hline & Male & 6 & 1 & 4 & 2 & 1 & 5 & 3 \\
\hline & Female & 5 & 3 & 2 & 2 & 1 & 3 & 3 \\
\hline & Children & 17 & 6 & 1 & 7 & 7 & 4 & \\
\hline 2 & Avg. landholding ac & 12 & & 7 & 3 & 5.5 & & 4 \\
\hline 3 & Owned land & 6 & 0 & 7 & 3 & 5.5 & 0 & 2 \\
\hline 4 & Rented land & 6 & 12.5 & 0 & 0 & 0 & 0 & 2 \\
\hline 6 & Herd size & 8 & & 4 & 8 & 4 & & 0 \\
\hline \multirow[t]{5}{*}{7} & Buffalo & 0 & 5 & 1 & 0 & 1 & 2 & \\
\hline & Cow & 3 & 4 & 1 & 4 & 1 & 1 & \\
\hline & Calves & 4 & 4 & 1 & 2 & 1 & 2 & \\
\hline & Heifers & 1 & 4 & 1 & 2 & 1 & 1 & \\
\hline & Bull & 0 & 0 & 0 & 0 & 0 & 0 & \\
\hline 8 & Farm manager's age & 60 & 40 & 73 & 37 & 40 & 65 & 42 \\
\hline 9 & Experience & 38 & 10 & 63 & 27 & 14 & 12 & 25 \\
\hline 10 & Education & 8 & 8 & 5 & 5 & 10 & 0 & 0 \\
\hline 11 & Value of farm equipment & 10,000 & 10,000 & 6,000 & 6,000 & 5,000 & 12,000 & \\
\hline
\end{tabular}




\begin{tabular}{|c|c|c|c|c|c|c|c|c|}
\hline 12 & Family labour (hours) & 4,880 & 4,880 & 4,880 & 3,660 & 2,440 & 6,710 & 1,220 \\
\hline 13 & Hired labour (hours) & 0 & 0 & 0 & 0 & 0 & 0 & \\
\hline 14 & $\begin{array}{l}\text { Income from dairy (milk } \\
\text { and meat) }\end{array}$ & 0 & 20,000 & 0 & 7,000 & 21,900 & 16,000 & \\
\hline 15 & $\begin{array}{l}\text { Income from other live- } \\
\text { stock }\end{array}$ & 0 & 40,000 & 1,2000 & 0 & 0 & 10,000 & 4,000 \\
\hline 16 & Area for cash crops & 4.5 & 10 & 6 & 2 & 4 & 0 & 2.4 \\
\hline 17 & Area for fodder crops & 1.2 & 2.5 & 1 & 1 & 1.4 & 0 & \\
\hline 18 & Distance from road(km) & 1 & 1 & 0.15 & 1 & 0.1 & 1.5 & 5 \\
\hline 19 & $\begin{array}{l}\text { Distance from milk coll. } \\
\text { center }(\mathrm{km})\end{array}$ & 3 & 5 & 4 & 5 & 3 & 3 & 3 \\
\hline 20 & Milk sale per day & 0 & 4 & 0 & 3 & 3 & 4 & \\
\hline 21 & Milk produced per day & 10 & 15 & 10 & 6 & 6 & 8 & \\
\hline 22 & $\begin{array}{l}\text { Milk price for Buffaloes } \\
\text { (Rs/kg) }\end{array}$ & 20 & 20 & 20 & 20 & 20 & 20 & \\
\hline 23 & $\begin{array}{l}\text { Milk price for cows } \\
\text { (Rs } / \mathrm{kg} \text { ) }\end{array}$ & 12 & 13 & 13 & 12 & 12 & 14 & \\
\hline
\end{tabular}




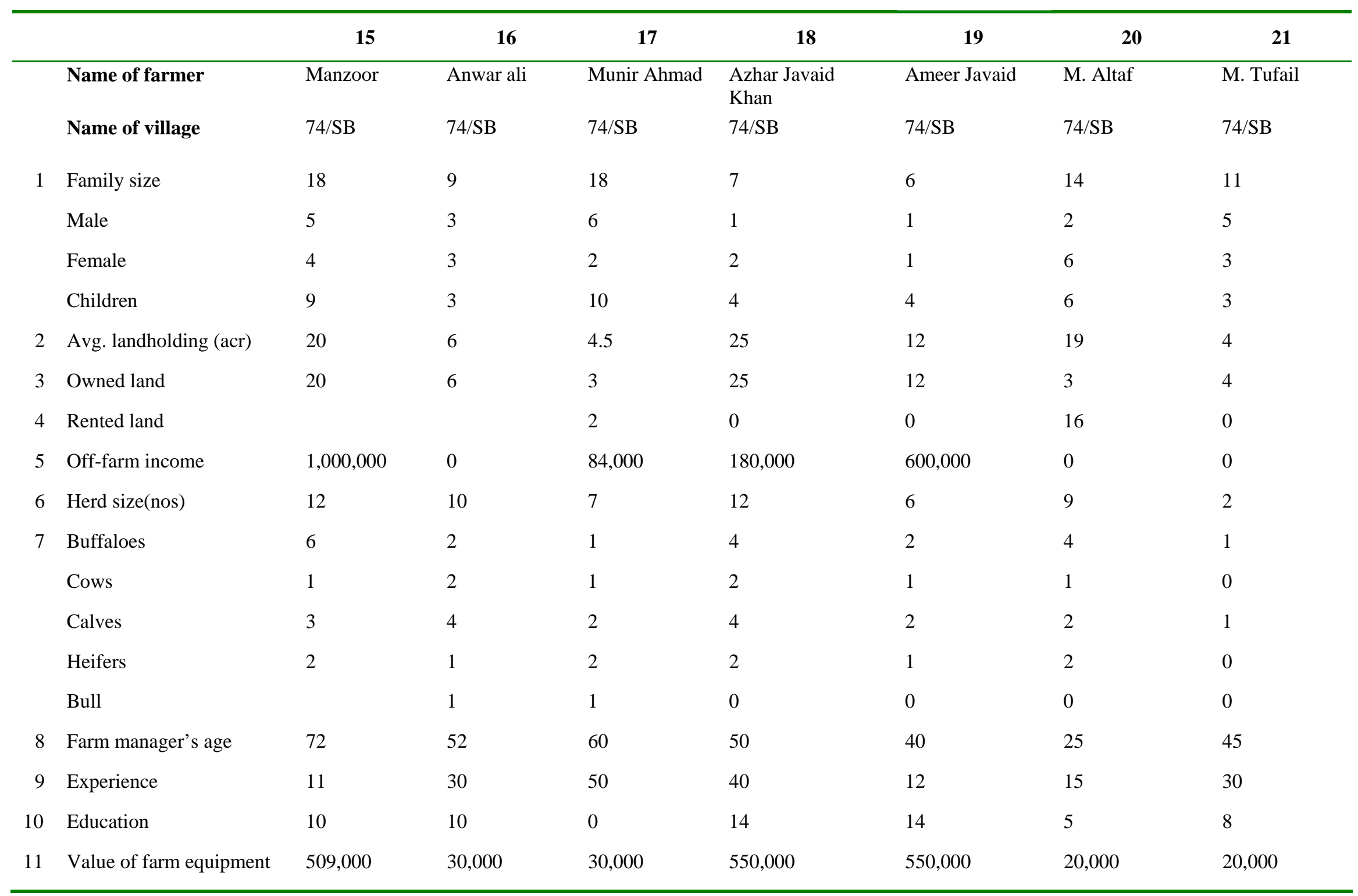




\begin{tabular}{|c|c|c|c|c|c|c|c|c|}
\hline 12 & Family labour (hours) & 2,960 & 6,100 & 5,490 & 2,560 & 2,440 & 4,880 & 3,660 \\
\hline 13 & Hired labour (hours) & 2,640 & 0 & 0 & 2,640 & 2,640 & 0 & 0 \\
\hline 14 & $\begin{array}{l}\text { Income from dairy (milk } \\
\text { and meat) }\end{array}$ & & 30,000 & 0 & 102,250 & 60,000 & 64,800 & 3,650 \\
\hline 15 & $\begin{array}{l}\text { Income from other live- } \\
\text { stock(sheep, goat, etc) }\end{array}$ & & 20,000 & 36,000 & 0 & 0 & 3,000 & 0 \\
\hline 16 & Area for cash crops & 17 & 4.5 & 3.9 & 20 & 9 & 17 & 3.5 \\
\hline 17 & Area for fodder crops & 3 & 1.5 & 0.6 & 5 & 3 & 2 & 0.5 \\
\hline 18 & Distance from road(km) & 0.5 & 0.5 & 0.5 & 2 & 3 & 0.25 & 0.25 \\
\hline 19 & $\begin{array}{l}\text { Distance from milk col- } \\
\text { lection center(km) }\end{array}$ & 4 & 4 & 4 & 4.5 & 2 & 3 & 3 \\
\hline 20 & Milk sale per day & & 7 & 0 & 15 & 0 & 10 & 5 \\
\hline 21 & Milk produced per day & 24 & 12 & 12 & 25 & 10 & 14 & 10 \\
\hline 22 & $\begin{array}{l}\text { Milk price for Buffaloes } \\
\text { (Rs/kg) }\end{array}$ & 17 & 17 & 17 & 16 & 16 & 20 & 20 \\
\hline 23 & $\begin{array}{l}\text { Milk price for cows } \\
\text { (Rs/kg) }\end{array}$ & 13 & 12 & 12 & 12 & 12 & 13 & 12 \\
\hline
\end{tabular}




\begin{tabular}{|c|c|c|c|c|c|c|c|c|c|}
\hline & & 22 & 23 & 24 & 25 & 26 & 27 & 28 & 29 \\
\hline & Name of farmer & Imam Deen & $\begin{array}{l}\text { Abdul Sha- } \\
\text { koor }\end{array}$ & $\begin{array}{l}\text { Nazir } \\
\text { Ahmad }\end{array}$ & Raiz Ahmad & Manzoor Ahmad & $\begin{array}{l}\text { Nasir } \\
\text { Ahmad }\end{array}$ & Nazir & Murad \\
\hline & Name of village & $74 / \mathrm{SB}$ & $74 / \mathrm{SB}$ & 74/SB & 105/SB & 105/SB & 105/SB & 105/SB & $105 / \mathrm{SB}$ \\
\hline \multirow[t]{4}{*}{1} & Family size & 4 & 24 & 8 & 9 & 10 & 6 & 37 & 11 \\
\hline & Male & 2 & 6 & 2 & 4 & 1 & 2 & 9 & 2 \\
\hline & Female & 2 & 6 & 2 & 2 & 8 & 3 & 8 & 2 \\
\hline & Children & 0 & 12 & 4 & 3 & 1 & 1 & 20 & 7 \\
\hline 2 & $\begin{array}{l}\text { Avg. landholding } \\
\text { (acr.) }\end{array}$ & 4 & 27.5 & 14 & 5 & 12.4 & 4.4 & 5 & 5 \\
\hline 3 & Owned land & 0 & 25 & 2 & 5 & 12.4 & 4.4 & 0 & 1 \\
\hline 4 & Rented land & 4 & 3 & 12 & 0 & 0 & 0 & 5 & 4 \\
\hline 5 & Off-farm income & 0 & 100,000 & 0 & 0 & 0 & 0 & 144,000 & 0 \\
\hline 6 & Herd size & 5 & 31 & 13 & 12 & 12 & 4 & 4 & 9 \\
\hline \multirow[t]{4}{*}{7} & Buffalo & 2 & 9 & 4 & 4 & 3 & 2 & 1 & 4 \\
\hline & Cow & 0 & 8 & 3 & 2 & 3 & 0 & 1 & 0 \\
\hline & Calves & 2 & 7 & 3 & 3 & 3 & 1 & 1 & 3 \\
\hline & Heifers & 1 & 7 & 3 & 3 & 3 & 1 & 1 & 2 \\
\hline 8 & Farm manager’s age & 70 & 70 & 40 & 45 & 60 & 29 & 80 & 75 \\
\hline 9 & Experience & 50 & 60 & 30 & 30 & 30 & 14 & 70 & 60 \\
\hline 10 & Education & 0 & 8 & 0 & 0 & 10 & 12 & 0 & 0 \\
\hline 11 & $\begin{array}{l}\text { Value of farm equip- } \\
\text { ment }\end{array}$ & 20,000 & 700,000 & 8,000 & 47,000 & 78,000 & 60,000 & 55,000 & 18,000 \\
\hline
\end{tabular}




\begin{tabular}{|c|c|c|c|c|c|c|c|c|c|}
\hline 12 & Family labour (hours) & 4,880 & 6,100 & 4,880 & 4,880 & 3,050 & 3,660 & 9,760 & 9,760 \\
\hline 13 & Hired labour (hours) & 0 & 2,640 & 0 & 0 & 0 & 0 & 0 & 0 \\
\hline 14 & $\begin{array}{l}\text { Income from dairy } \\
\text { (milk and meat) }\end{array}$ & 5,000 & 50,000 & 12,000 & 6,000 & 0 & 5,000 & 0 & 7,000 \\
\hline 15 & $\begin{array}{l}\text { Income from other } \\
\text { livestock }\end{array}$ & 0 & 0 & 0 & 0 & 0 & 0 & 0 & 0 \\
\hline 16 & Area for cash crops & 3 & 25 & 16 & 2 & 10 & 2.9 & 3.4 & 1 \\
\hline 17 & Area for fodder crops & 1 & 3 & 3 & 3 & 2,2 & 1.1 & 1.5 & 2 \\
\hline 18 & $\begin{array}{l}\text { Distance from } \\
\text { road(km) }\end{array}$ & 1 & 2 & 0.15 & 0.15 & 0.15 & 0.15 & 0.15 & 0.15 \\
\hline 19 & $\begin{array}{l}\text { Distance from milk } \\
\text { collection center }(\mathrm{km})\end{array}$ & 3 & 3 & 3 & 3 & 3 & 3 & 3 & 3 \\
\hline 20 & Milk sale per day & 2.5 & 0 & 5 & 20 & 10 & 0 & 0 & 10 \\
\hline 21 & $\begin{array}{l}\text { Milk produced per } \\
\text { day }\end{array}$ & 10 & 22 & 15 & 25 & 16 & 8 & 5 & 12 \\
\hline 22 & $\begin{array}{l}\text { Milk price for Buffa- } \\
\text { loes (Rs/kg) }\end{array}$ & 20 & 20 & 20 & 20 & 18 & 16 & 16 & 16 \\
\hline 23 & $\begin{array}{l}\text { Milk price for cows } \\
\text { (Rs/kg) }\end{array}$ & 12 & 12 & 13 & 15 & 15 & 15 & 15 & 15 \\
\hline
\end{tabular}




\begin{tabular}{|c|c|c|c|c|c|c|c|c|}
\hline & & 30 & 31 & 32 & 33 & 34 & 35 & 36 \\
\hline & Name of farmer & $\begin{array}{l}\text { Tuswar } \\
\text { Abbas }\end{array}$ & Aziz Ahmad & Ifikhar Ali & $\begin{array}{l}\text { Irahad ullah \& } \\
\text { sana ullah }\end{array}$ & $\begin{array}{l}\text { Zaigham } \\
\text { Mahmood }\end{array}$ & $\begin{array}{l}\text { Arshad } \\
\text { Zaman }\end{array}$ & $\begin{array}{l}\text { Aftab } \\
\text { Ahmad }\end{array}$ \\
\hline & Name of village & 105/SB & $105 / \mathrm{SB}$ & $105 / \mathrm{SB}$ & 105/SB & $105 / \mathrm{SB}$ & 105/SB & $105 / \mathrm{SB}$ \\
\hline \multirow[t]{4}{*}{1} & Family size & 5 & 6 & 6 & 14 & 13 & 2 & 7 \\
\hline & Male & 1 & 3 & 1 & 4 & 3 & 1 & 2 \\
\hline & Female & 1 & 2 & 2 & 2 & 4 & 1 & 2 \\
\hline & Children & 3 & 1 & 3 & 8 & 6 & 0 & 3 \\
\hline 2 & Avg. landholding (acr) & 4.4 & 5 & 3 & 55 & 16 & 16 & 3 \\
\hline 3 & Owned land & 4.4 & 5 & 3 & 55 & 10 & 8 & 3 \\
\hline 4 & Rented land & 0 & 0 & 0 & 0 & 6 & 8 & 0 \\
\hline 5 & Off-farm income & 0 & 0 & 0 & 0 & 0 & 15,6000 & 24,000 \\
\hline 6 & Herd size & 11 & 7 & 6 & 29 & 10 & 17 & 6 \\
\hline \multirow[t]{5}{*}{7} & Buffalo & 3 & 3 & 0 & 9 & 2 & 6 & 1 \\
\hline & Cow & 3 & 1 & 3 & 5 & 3 & 3 & 2 \\
\hline & Calves & 2 & 2 & 2 & 8 & 3 & 5 & 2 \\
\hline & Heifers & 3 & 1 & 1 & 6 & 2 & 3 & 1 \\
\hline & Bull & 0 & 0 & 0 & 1 & 0 & 0 & \\
\hline 8 & Farm manager's age & 44 & 23 & 42 & 65 & 43 & 46 & 47 \\
\hline 9 & Experience & 34 & 13 & 32 & 30 & 5 & 4 & 12 \\
\hline 10 & Education & 10 & 5 & 5 & 10 & 12 & 12 & 10 \\
\hline 11 & Value of farm equipment & 10,000 & 75,000 & 10,000 & 500,000 & 600,000 & 600,000 & 25,000 \\
\hline
\end{tabular}




\begin{tabular}{|c|c|c|c|c|c|c|c|c|}
\hline 12 & Family labour (hours) & 2,440 & 4,880 & 4,880 & 2,230 & 2,840 & 3,600 & 730 \\
\hline 13 & Hired labour (hours) & 0 & 0 & 0 & 9,760 & 2,640 & 5,280 & 240 \\
\hline 14 & Income from dairy (milk and meat) & 4,000 & 4,000 & 2,000 & 200,000 & 15,000 & 25,0000 & 6,000 \\
\hline 15 & $\begin{array}{l}\text { Income from other livestock (sheep, goat, } \\
\text { etc.) }\end{array}$ & 0 & 0 & 0 & 0 & 0 & 5,000 & 0 \\
\hline 16 & Area for cash crops & 3 & 3 & 2 & 49 & 13 & 14 & 2.2 \\
\hline 17 & Area for fodder crops & 1 & 2 & 1 & 6 & 3 & 2 & 0.6 \\
\hline 18 & Distance from road(km) & 1 & 0.15 & 1.5 & 0 & 1 & 0.5 & 1 \\
\hline 19 & Distance from milk collection center $(\mathrm{km})$ & 2 & 2 & 2 & 3 & 4 & 3 & 12 \\
\hline 20 & Milk sale per day & 4 & 0 & 6 & 15 & 5 & 32 & 0 \\
\hline 21 & Milk produced per day & 8 & 7 & 10 & 36 & 15 & 45 & 6 \\
\hline 22 & Milk price for Buffaloes (Rs/kg) & 15 & 20 & 20 & 20 & 18 & 16 & 18 \\
\hline 23 & Milk price for cows (Rs/kg) & 13 & 15 & 14 & 14 & 14 & 13 & 14 \\
\hline
\end{tabular}




\section{Curriculum Vitae}

Name:

Email:

Date and place of birth

Nationality

Marital status

\section{Khalid Mahmood}

khalidlodhra@yahoo.co.uk

15.06.1974 in Layyah, Pakistan

Pakistani

Married, two children

1980 - 1985 Govt. Primary School, Bhadianwalla, Karor, Pakistan, (Primary school certificate)

1985 - 1990 Govt. High School, Railway Road, Karor, Pakistan, (Matric / secondary school certificate).

1991 - 1992 Govt. Degree College Layyah, Pakistan, F.Sc (Pre-medical / higher secondary school certificate).

1992 - 1996 University of Arid Agriculture, Rawalpindi, Pakistan, B.Sc. (Hons.).

1996 - 1998 University Institute of Management Sciences (UIMS), University of Arid Agriculture, Rawalpindi, Pakistan, (MBA).

1999 - 2003 Agribusiness specialist, Small and Medium Enterprise Development Authority (SMEDA), Lahore, Pakistan.

2003 - 2005 Research Associate, Institute of Farm Economics, Federal Agriculture Research Center (FAL), Braunschweig, Germany.

2005 - 2006 Dairy Economist, International Farm Comparison Network (IFCN) Dairy Research Center, Braunschweig, Germany.

2003 - 2008 Doctoral student in Faculty of Agricultural Sciences, George August University, Göttingen, Germany. 